\title{
ipen
}

INSTITUTO DE PESQUISAS ENERGÉTICAS E NUCLEARES Autarquia associada à Universidade de São Paulo

\section{ANÁLISE CRÍTICA PARA ADEQUAÇÃO FÍSICA E IMPLANTAÇÃO DE NOVOS PROCEDIMENTOS NA DIVISÃO DE ANIMAIS DE LABORATÓRIO DO IPEN}

ELIZABETH BRIGAGÃO DE FARIA LAINETTI

Dissertação apresentada como parte dos requisitos para obtenção do Grau de Mestre em Ciências na Área de Tecnologia Nuclear Aplicações.

Orientadora:

Prof $^{\mathrm{a}}$. Dr ${ }^{\mathrm{a}}$. Nanci do Nascimento

São Paulo 
"O maior erro da ética é a crença de que ela só pode ser aplicada em relação aos homens." 
Dedico este trabalho ao meu esposo, Paulo Ernesto, às nossas filhas, Fabiana e Patrícia, à minha mãe Cecy e à memória do meu pai, William, pelo amor, apoio, compreensão e simplesmente, por tudo que representam na minha vida. 


\section{AGRADECIMENTOS}

À Prof ${ }^{a}$. Dr ${ }^{a}$ Nanci do Nascimento, o meu mais sincero agradecimento pela orientação neste trabalho, apoio, atenção por todas as vezes que precisei, por ajudar no meu crescimento profissional e, sobretudo, pela amizade.

Ao Instituto de Pesquisas Energéticas e Nucleares e ao seu Superintendente, Dr. Nilson Dias Vieira Júnior, pela oportunidade oferecida.

Ao Prof. Dr. Luiz Augusto Corrêa Passos pelo inestimável apoio no desenvolvimento deste trabalho.

Aos funcionários do Biotério do IPEN, pela paciência e atenção, em particular a Maria Neide F. Mascarenhas, pela ajuda, visita aos Biotérios e amizade.

À Divisão de Projetos e Obras (DIE/DPO) do IPEN, Cláudia de Fátima de O. Mouro, Arq. Luiz Massi Júnior e $\mathrm{Eng}^{\circ}$ Reinaldo L. Caratin, pelo apoio na realização deste trabalho, convívio e amizade.

A Divisão de Operação do Campus (DOC/IPEN), Amadeu Ferreira, Gilberto Magalhães e Pedro Mariano, pelo apoio na execução de serviços no Biotério.

A Edna Maria Alves e aos funcionários da Biblioteca do IPEN, pela paciência.

A Aninha, Rose e Verinha, da Divisão de Ensino (DE/IPEN), pela amizade.

À Prof ${ }^{\text {a. }}$ Dr ${ }^{\text {a. }}$ Ubimara, do Instituto Butantan, pela visita e orientações.

Ao Cláudio L. de Castro, Regina De Luca e Thaís Marques, pela visita ao Biotério do Instituto de Ciências Biomédicas (ICB/USP) e ao Robson J. da Cruz, pelas fotos do Biotério da Faculdade de Medicina da Universidade de São Paulo.

Ao Prof. Dr. José Luiz B. Merusse, da Faculdade de Medicina Veterinária e Zootecnia da USP (FMVZ-USP), pela atenção e documentos fornecidos.

Aos queridos e eternos amigos Doly M. de Amorim e Hernani Amorim, a minha gratidão in memorian, pela oportunidade no início da minha vida profissional, pela amizade e carinho que sempre tiveram comigo.

Ao meu esposo, Paulo, por tudo que me ajudou, e às minhas filhas, Fabiana e Patrícia, pelo incentivo, apoio prestado durante todo o trabalho e compreensão.

À minha mãe Cecy, pelo incentivo e dedicação. Ao meu querido pai William, in memorian, pela educação e exemplo, e ao meu irmão, William, pelo incentivo.

Ao Felipe Farah Motta pelas imagens tridimensionais.

A todos aqueles que, direta ou indiretamente, auxiliaram na realização deste trabalho. 


\title{
ANÁLISE CRÍTICA PARA ADEQUAÇÃO FÍSICA E IMPLANTAÇÃO DE NOVOS PROCEDIMENTOS NA DIVISÃO DE ANIMAIS DE LABORATÓRIO DO IPEN
}

\begin{abstract}
RESUMO
A produção e o fornecimento de animais de laboratório de alta qualidade são de importância fundamental para a realização de pesquisas científicas de vanguarda, com reprodutibilidade e universalidade. Por sua vez, a qualidade desses animais depende, em grande parte, das instalações disponíveis para a sua produção e alojamento, de forma a garantir as condições necessárias ao seu bem-estar e segurança, atendendo aos princípios éticos que regem a atividade. As instalações também têm de preencher outros requisitos, tais como: a funcionalidade dos ambientes, que devem possibilitar o manejo adequado e eficiente dos animais, facilitando a execução das atividades rotineiras; o respeito a princípios ergonômicos, para proporcionar um ambiente seguro e o bem-estar dos operadores. O projeto das instalações é de importância vital para que os requisitos mencionados sejam atingidos. O Biotério do Instituto de Pesquisas Energéticas e Nucleares (IPEN) foi projetado no ano de 1964 e as instalações foram planejadas com o objetivo de ser uma unidade de produção e manutenção de animais, contudo, naquela época não havia as recomendações atuais no que diz respeito ao controle sanitário, genético e ambiental. Assim, o desenho original da unidade apresenta uma distribuição de área inadequada, que impossibilita a completa segregação de animais pós-ensaio, colônias de produção e estoque, bem como animais portadores de alterações em seu "background" genético. A instalação do biotério ocupa uma área de $840 \mathrm{~m}^{2}$, com um pavimento, onde estão distribuídas as áreas de produção e estoque de modelos animais originários da própria instituição, bem como a manutenção de animais oriundos de outras instituições nacionais e do exterior. O Biotério do IPEN fornece animais para testes biológicos dos lotes de radiofármacos, produzidos na Diretoria de Radiofármacos - DIRF - do IPEN, antes de serem enviados aos hospitais e clínicas de todo o Brasil, para utilização na Medicina Nuclear. Fornece também ratos e camundongos para testes de materiais odontológicos, ensaios com hormônios e para pesquisas de novos fármacos e radiofármacos, dentre outros. Muitos dos modelos produzidos no IPEN são únicos no Brasil e constituem-se, portanto, em um importante patrimônio que deve ser preservado. Este trabalho descreve as atividades que vêm sendo executadas atualmente no Biotério do IPEN, englobando o projeto de reforma e a adequação das instalações.
\end{abstract}




\title{
CRITICAL ANALYSIS FOR PHYSICAL ADAPTATION AND IMPLEMENTATION OF NEW PROCEDURES IN THE IPEN'S LABORATORY ANIMAL DIVISION
}

\begin{abstract}
The production and the supply of high quality laboratory animals have fundamental importance for the accomplishment of vanguard scientific research, with reproducibility and universality. The quality of those animals depends, largely, of the available facilities for their production and lodging, to assure the demanded sanitary control and animals' welfare, in agreement with the ethical principles that control the activity. The facilities also have to fill out other requirements, such as: the functionality of the environments to make possible the suitable and efficient handling of the animals, facilitating the execution of the routine activities; the respect to ergonomic principles to provide a safe environment and the operators' well being. The facilities design is of vital importance so that the mentioned requirements can be reached. The project of the Nuclear and Energy Research Institute (IPEN) Animal House Facilities was accomplished in the year of 1964 . However, by that time there were not the current recommendations with respect to the sanitary, genetic and environmental controls. The facility was planned with the objective of being a production unit and a local for keeping of defined animals from sanitary, genetic and environmental point of view. Nevertheless, the original unit drawing presents an unsuitable distribution of the area where animals are stocked and also different activities are performed. The Animal House Facilities occupy an area of $840 \mathrm{~m}^{2}$, with one pavement, where the production areas and the stock of original animal models of the own Institution are distributed, as well as the maintenance of animals from other national or foreigner institutions. It supplies rats and mice for biological tests of radiopharmaceutical lots, produced in IPEN, before they be sent to hospitals and clinics spread out in Brazil, for use in Nuclear Medicine. It also supplies rats and mice for tests of odontological materials, for tests with growth hormones and for researches of new pharmaceuticals and radiopharmaceuticals, among others applications. Many of the animals models produced in IPEN are unique in Brazil and they constitute, therefore, an important patrimony that should be preserved. This paper describes the activities that have been executed in Animal House Facilities of IPEN, including the refurbishment project and the adaptation of the facilities.
\end{abstract}




\section{SUMÁRIO}

\section{Página}

RESUMO

ABSTRACT

I. INTRODUÇÃO

II. OBJETIVOS 2

II.1 Geral 2

II.2 Específicos 2

III. ESTADO DA ARTE 3

III.1 Histórico da Utilização de Animais de Laboratório 3

III.2 Conceitos e Definições dos Animais de Laboratório 5

III.3 Qualidade Sanitária e Cuidados com os Animais de Laboratório 6

III.3.1 Padrão genético dos animais de laboratório 8

III.3.2 Importância das patologias dos animais de laboratório 10

III.3.3 Quarentena 12

III.3.4 Princípios éticos para o uso dos animais de laboratório 14

III.3.5 Estresse e bem-estar dos animais de laboratórios 18

III.4 Biossegurança $\quad 22$

III.4.1 Barreira sanitária e de contenção 25

III.4.2 Biossegurança em biotérios $\quad 29$

III.5 Aspectos Relevantes do Ambiente Físico 47

III.5.1 Micro e macro ambiente $\quad 49$

III.5.2 Temperatura e umidade 51

III.5.3 Ventilação $\quad 54$

III.5.4 lluminação $\quad 55$

III.5.5 Ruído $\quad 57$

III.6 Arquitetura em biotérios $\quad 59$

III.6.1 Materiais de construção utilizados em biotérios 66 
IV.1 Situação atual das Instalações do Biotério do IPEN/CNEN-SP 71

IV.1.1 Descrição das atuais instalações 71

IV.1.2 Localização e usuários $\quad 71$

IV.1.3 Principais problemas identificados nas instalações $\quad 72$

IV.1.4 Problemas identificados nas salas de criação 73

IV.1.5 Problemas identificados nos acessos e áreas de circulação $\quad 75$

IV.1.6 Problemas identificados nas áreas de apoio 78

IV.2 Procedimentos atuais adotados nas instalações do Biotério 81 do IPEN/CNEN-SP

IV.2.1 Procedimentos de acesso $\quad 81$

IV.2.2 Procedimentos de limpeza e desinfecção $\quad 81$

IV.2.3 Procedimentos de fluxo $\quad 83$

V. RESULTADOS E DISCUSSÃO 84

V.1 Projeto da primeira etapa da adequação e reforma das instalações $\quad 84$ do Biotério do IPEN/CNEN-SP

V.1.1 Adequação das salas de criação 86

V.1.2 Instalação de barreiras sanitárias $\quad 87$

V.1.3 Utilização de materiais e instalação de equipamentos mais $\quad 91$ adequados

V.1.4 Instalação de novo sistema de ventilação 96

V.2 Projeto da segunda etapa da adequação e reforma das instalações $\quad 100$ do Biotério do IPEN/CNEN-SP

V.2.1 Modificações a serem introduzidas na segunda etapa da reforma 101

V.2.1.1 Acesso ao Biotério 101

V.2.1.2 Isolamento da área da copa $\quad 102$

V.2.1.3 Isolamento da área do jardim 102

V.2.1.4 Fluxo e segregação das áreas de criação e experimentação 103

V.2.1.5 Distribuição dos ambientes no setor de criação de animais $\quad 105$

V.2.1.6 Distribuição dos ambientes no setor de experimentação de 106 animais

V.3 Novos procedimentos a serem instituídos nas instalações do Biotério 107 do IPEN/CNEN-SP

V.3.1 Considerações críticas sobre a reforma 
V.4 Memorial descritivo da segunda etapa da adequação e reforma das Instalações do Biotério do IPEN/CNEN-SP

V.4.1 Especificação

V.4.1.1 Demolição

V.4.1.2 Fundações

V.4.1.3 Alvenaria de elevação

V.4.1.4 Revestimento

V.4.1.5 Piso

V.4.1.6 Azulejo

V.4.1.7 Portas

V.4.1.8 Caixilhos de alumínio

V.4.1.9 Soleira, peitoril, bancadas e gabinete

V.4.1.10 Forro

V.4.1.11 Portas e caixilhos em vidro

V.4.1.12 Divisórias

V.4.1.13 Louças e metais

V.4.1.14 Blocos de vidro

V.4.1.15 Guichê

V.4.1.16 Cobertura

V.4.1.17 Pintura

V.4.1.18 Passeio

V.4.1.19 Cobertura em policarbonato

V.4.1.20 Instalação elétrica

V.4.1.21 Instalação hidráulica 


\section{LISTA DE FIGURAS}

Página

FIGURA 1: Fatores ambientais e de gerenciamento que afetam a homeostase animal.

FIGURA 2: Esquema dos quatro níveis de Biossegurança Animal. 32

FIGURA 3: Salas revestidas com azulejos no Biotério do IPEN. 73

FIGURA 4: Prateleiras existentes no Biotério do IPEN.

FIGURA 5: Janelas com abertura para o exterior. 74

FIGURA 6: Portas deterioradas. 74

FIGURA 7: Luminária de sobrepor existente. 75

FIGURA 8: Entrada principal do biotério do IPEN. 76

FIGURA 9: Elemento vazado nas circulações do prédio. 76

FIGURA 10: Ralo com grelha existente no piso da circulação. 77

FIGURA 11: Abertura na alvenaria. 77

FIGURA 12: Copa existente na área do Biotério do IPEN. 78

FIGURA 13: Sala de Estocagem de Maravalha. 79

FIGURA 14: Sala de Estocagem de Ração. 79

FIGURA 15: Canaleta com grelha no piso. 80

FIGURA 16: Tanques existentes na Sala de lavagem. 80

FIGURA 17: Mini-isoladores "sujos”. 82

FIGURA 18: Corredor. 82

FIGURA 19: Planta do Biotério do IPEN. 84

FIGURA 20: Planta da primeira etapa da reforma. 85

FIGURA 21: Corredor asséptico após a primeira etapa da reforma. 87

FIGURA 22: Corredor séptico após a primeira etapa da reforma. 88

FIGURA 23 Porta tipo balcão. 88

FIGURA 24: Pass through instalado na circulação asséptica.

FIGURA 25: Pass through instalado na circulação séptica.

FIGURA 26: Pass through instalado para atender fornecimento de 89 animais.

FIGURA 27: Passagem do banheiro feminino e armário. 90

FIGURA 28: Passagem do banheiro masculino e armário. 90

FIGURA 29: Autoclaves de barreira. 
FIGURA 30: Luminária de embutir vedada.

FIGURA 31: Fechamento das alvenarias.

FIGURA 32: Instalação de vidros fixos.

FIGURA 33: Protetores nas alvenarias.

FIGURA 34: Protetores contra insetos.

FIGURA 35: Instalação de timer.

FIGURA 36: Circulação.

FIGURA 37: Portas com visores.

FIGURA 38: Revestimento de azulejos nos tanques.

FIGURA 39: Fechamento de canaleta no piso.

FIGURA 40: Visores com vidro duplo.

FIGURA 41: Entrada para sala de equipamento.

FIGURA 42: Grelha no forro.

FIGURA 43: Grelha na alvenaria.

FIGURA 44: Mini-isolador, da Alesco Ind. e Com.

FIGURA 45: Racks ventilados instalados no Biotério do IPEN.

FIGURA 46: Estantes ventiladas instaladas no Biotério do IPEN.

FIGURA 47: Planta da segunda etapa da reforma.

FIGURA 48: Futura entrada para salas de criação.

FIGURA 49: Local a ser fechado com blocos de vidro.

FIGURA 50: Jardim a ser isolado.

FIGURA 51: Exemplo de fechadura com controle de acesso rápido.

FIGURA 52: Planta com fluxo a ser implantado.

FIGURA 53: Futura entrada da área de criação.

FIGURA 54: Futura entrada da área de experimentação.

FIGURA 55: Futuro fechamento do jardim.

FIGURA 56: Local para paramentação com roupa estéril. 


\section{LISTA DE TABELAS}

\section{Página}

TABELA 1: Principais zoonoses. $\quad 11$

TABELA 2: Espaço recomendado para roedores de laboratório comumente 50 usados e alojados em grupos.

TABELA 3: Condições ambientais.

TABELA 4: Temperaturas recomendadas para animais usados comumente 53 em laboratório.

TABELA 5: Intervalo de freqüência e faixa de sensibilidade auditiva de algumas espécies.

TABELA 6: Resumo dos Requisitos Conforme o Nível de Biossegurança Animal.

TABELA 7: Relação de Materiais Considerando o Nível de Biossegurança Animal.

TABELA 8: Lista de materiais propostos a serem utilizados na reforma. 


\section{INTRODUÇÃO}

A produção e o fornecimento de animais de laboratório de alta qualidade são de importância fundamental para a realização de pesquisas científicas de vanguarda, com reprodutibilidade e universalidade. Por sua vez, a qualidade desses animais depende, em grande parte, das instalações disponíveis para a sua produção e alojamento, de forma a garantir o controle sanitário exigido e o seu bem-estar de acordo com os princípios éticos que regem a atividade.

As instalações também têm de preencher outros requisitos, tais como: a funcionalidade dos ambientes, que devem possibilitar o manejo adequado e eficiente dos animais, facilitando a execução das atividades rotineiras; o respeito a princípios ergonômicos, para proporcionar um ambiente seguro e o bem-estar dos operadores. Sua construção, operação e manutenção devem ser realizadas respeitando critérios mínimos do ponto de vista dos custos e da eficácia.

O projeto das instalações é de importância vital para que os requisitos mencionados sejam atingidos. Contudo, o biotério do IPEN já existe há mais de 40 anos e, como em toda instalação, o tempo promoveu o desgaste de materiais e componentes. Além disso, o avanço nos conhecimentos e o aumento dos requisitos de qualidade para os animais produzidos, aliados à disponibilidade de novos materiais e de novas soluções construtivas, exigiram a reavaliação do layout da instalação e manutenções corretivas. 


\section{OBJETIVOS}

\section{II.1 Geral}

Gerar uma proposta de adequação física para o Biotério do IPEN, com implantação de novos procedimentos, de forma a permitir um manejo adequado para a produção de animais padronizados ou até mesmo certificados do ponto de vista sanitário, genético e de ambiente, que serão usados nos testes dos radiofármacos produzidos no IPEN, bem como às pesquisas científicas desenvolvidas no Instituto. Todo o processo visa ainda facilitar a execução das atividades pelos operadores, de acordo com princípios ergonômicos e éticos, seguindo as normas de biossegurança e respeitando as limitações impostas pelas restrições orçamentárias e pelas condições pré-existentes.

Uma vez que o IPEN é uma instituição multidisciplinar, os profissionais das áreas de engenharia e apoio nem sempre dispõem da formação e dos conhecimentos necessários para atender às demandas dos diversos usuários. Dessa forma, um objetivo mais amplo deste trabalho de mestrado seria a capacitação de pessoal qualificado para atendimento das demandas e exigências específicas do Biotério do IPEN.

De maneira geral, os conhecimentos adquiridos neste trabalho poderão ser aplicados na construção, reforma e adequação de outros setores do Instituto, que necessitem introduzir áreas para uso com modelos animais.

\section{II.2 Específicos}

- Eliminar o contato direto com a área externa do prédio;

- Limitar o acesso das pessoas;

- Garantir o bem-estar dos animais e dos operadores;

- Melhorar as instalações e os fluxos de insumos e pessoas;

- Segregar as áreas de criação e experimentação;

- Atender às normas de biossegurança.

- Permitir a criação de novos modelos animais 


\section{ESTADO DA ARTE}

\section{III.1 Histórico da Utilização de Animais de Laboratório}

A utilização de animais de laboratório em investigação biológica teve, inicialmente, estreita relação com a "patologia comparada". Na época, como as autópsias em cadáveres humanos estavam proibidas, os cientistas procuravam nos animais a origem e as características dos processos patológicos que afetavam a espécie humana, fazendo necropsias nesses animais para deduzir semelhanças.

Cientistas como Aristóteles, Galeno, Hipócrates, entre outros, estudaram as semelhanças e diferenças entre os órgãos dos animais e do homem, interpretaram fenômenos biológicos, descobriram o funcionamento de órgãos, estudaram a respiração, a circulação sanguínea, a nutrição e os processos de digestão, utilizando várias espécies de animais. Isso aconteceu alguns anos antes de Cristo e foi o começo do uso de animais de laboratório, que contribuíram sobremaneira para o desenvolvimento da ciência. Posteriormente, com os estudos da bacteriologia, a utilização de animais de laboratório tornou-se cada vez mais necessária. Desde os primeiros trabalhos de Pasteur e Koch, no século XVIII, cobaias, coelhos, ratos, camundongos e hamsters passaram a ser "ferramenta de trabalho" dos pesquisadores, indispensável para identificar os germes causadores das enfermidades contagiosas. As primeiras vacinas contra o carbúnculo bacteriano e contra a raiva não teriam sido produzidas sem a experimentação nesses animais (ANDRADE, 2006).

Aristóteles já conhecia e utilizava camundongos brancos em seus estudos. O camundongo doméstico é o antepassado do camundongo de laboratório (Mus domesticus domesticus), que no século XIX passou a ser empregado em delineamentos experimentais (produção, pesquisa, testes ou ensaios), sendo considerada a espécie eleita de várias áreas da investigação biomédica, como por exemplo, em pesquisas sobre o câncer (SOUZA \& MERUSSE, 1996). 
Em 1934, no Brasil, surgiu o Decreto Federal $n^{\circ} 24.645$, assegurando proteção a todos os animais, embora não houvesse, nesse texto, artigo expresso sobre animais de laboratório. Em 1979, foi editada a Lei Federal nº 6.638 (Diário Oficial da União - 8 de maio de 1979), estabelecendo normas a práticas didáticocientíficas da vivissecção de animais, regulamentando os registros dos biotérios e centros de experimentação, enfatizando que as pesquisas devem obedecer sempre a critérios mínimos do não sofrimento dos animais envolvidos e penalizando os infratores. O Decreto Lei $n^{\circ}$ 64.704, de 17 de junho de 1969, Capítulo II, Art. $2^{\circ}$, itens "c" e "d", estipula ser o exercício da medicina de animais de laboratório uma atividade profissional privativa do médico-veterinário. Isto quer dizer que todo biotério deve possuir um médico veterinário especializado em animais de laboratório (MEZADRI; TOMÁZ; AMARAL, 2004).

Atualmente, a Lei Federal $n^{\circ} 11.794$ (Diário Oficial da União - 8 de outubro de 2008), estabelece procedimentos para o uso científico de animais, cria o Conselho Nacional de Controle de Experimentação Animal - CONCEA e a Comissão de Ética no Uso de Animais - CEUAs, condição indispensável para o credenciamento das instituições com atividades de ensino ou pesquisa com animais, porém, ainda não foi regulamentada. Essa lei revoga a Lei $n^{\circ} 6.638$, de 8 de maio de 1979.

Analisando-se historicamente, verifica-se que até a década de 70, o Brasil apresentava uma situação precária quanto às instalações e cuidados na produção de animais utilizados em trabalhos experimentais. Contudo, esse quadro tem mudado, constituindo grande avanço, devido ao trabalho realizado por algumas instituições oficiais, no sentido de construir biotérios em condições adequadas, com apropriado sistema de climatização e com barreiras físicas contra a propagação de infecções, considerados elementos fundamentais para esse tipo de construção. Algumas dessas instituições já produzem animais "S.P.F." (livres de germes patogênicos específicos) e gnotobióticos (flora conhecida) (ANDRADE, 2006).

Foi inaugurado, em 1979, o Biotério Central da UNICAMP (Universidade Estadual de Campinas), com o objetivo de proporcionar aos pesquisadores das 
diversas áreas das ciências biológicas e biomédicas da Universidade o acesso a animais de experimentação de qualidade. Em 1985, a FAPESP (Fundação de Amparo à Pesquisa do Estado de São Paulo), aprovou o programa Centro MultiInstitucional de Bioterismo (CEMIB), visando contemplar às necessidades de pesquisadores e sociedades científicas da universidade, com readequação do espaço físico dos biotérios, instalação de rotinas de controle de qualidade animal e treinamento de pessoal. Com a instalação do programa e com a ajuda de técnicos, professores e cientistas, o Biotério Central da UNICAMP, passou por reformas estruturais e instalou os programas de controle necessários, com a finalidade de produzir animais livres de patógenos específicos, com procedência genética garantida. Em 1989, foi criada a denominação CEMIB/UNICAMP, que atualmente desempenha um papel importante como Centro de desenvolvimento tecnológico e científico, realizando pesquisa na área de Ciência em Animais de Laboratório, com reconhecimento internacional e único representante do ICLAS (International Council for Laboratory Animal Science) na América Latina.

Segundo ANDRADE (2006):

“Um biotério nada mais é que uma instalação dotada de características próprias, que atende às exigências dos animais onde são criados ou mantidos, proporcionando-Ihes bem-estar e saúde para que possam se desenvolver e reproduzir, bem como para responder satisfatoriamente aos testes neles realizados".

Este mesmo autor afirma que o importante progresso nesta área, alcançado nos últimos 30 anos, exige o treinamento de profissionais de nível superior na especialidade "Animais de Laboratório", bem como a capacitação de técnicos que desenvolvam suas atividades em biotérios de criação e experimentação, visando à segurança de todos os funcionários e principalmente daqueles que atuam diretamente no manejo com os animais.

\section{III.2 Conceitos e Definições dos Animais de Laboratório}

Quando falamos em reagentes biológicos, estamos também nos referindo aos animais utilizados em experimentação. Quando um experimento é realizado, 
o pesquisador procura reagentes da mais pura origem e livres de contaminantes, para garantir a qualidade dos resultados nas pesquisas.

Camundongo (Mus domesticu domesticus), Rato (Rattus norvegicus), Hamster (Mesocricetus auratus), Cobaia (Cavia porcellus) e Coelho (Oryctolagus cuniculus) são espécies convencionais de animais de laboratório, com vantagens e desvantagens (VALERO et al., 1990).

Vantagens dos animais de laboratório:

- Fácil manutenção e observação;

- Torna possível que se trabalhe com número muito grande de indivíduos;

- Possuem ciclos vitais curtos (gestação, lactação, puberdade, etc.);

- Permitem a padronização do ambiente;

- Permitem padronização genética;

- Grande quantidade de informações básicas é disponível.

Desvantagens dos animais de laboratório:

- Vivem em ambiente totalmente artificial;

- Dieta padronizada;

- As doenças são artificialmente induzidas.

\section{III.3 Qualidade Sanitária e Cuidados com os Animais de Laboratório}

Os animais de laboratório são considerados elementos fundamentais da experimentação, portanto, é indispensável a sua padronização para uso em pesquisas, pois diminui o número de animais necessários para atingir a exatidão do experimento (MEZADRI; TOMÁZ; AMARAL, 2004).

Por meio de técnicas especiais de criação e manutenção, podemos ter animais livres de qualquer forma de vida associada. Ao conjunto de formas de vida associadas denominamos microbiota (vírus, bactérias, fungos e parasitas). Quanto mais eficientes forem as barreiras sanitárias do biotério, menores as chances de contaminação dos animais. 
Segundo SOUZA \& MERUSSE (1996) os animais podem ser classificados de acordo com seu padrão sanitário, ou seja, quanto à microbiota a eles associada, em:

Convencional ou holoxênicos: são animais de padrão sanitário convencional, ou seja, que possuem microbiota indefinida, por serem mantidos em ambiente desprovido de barreiras sanitárias rigorosas. A criação desses animais apresenta apenas princípios básicos de higiene onde se realiza a limpeza e a desinfecção do ambiente e do material utilizado.

\section{Livres de patógenos específicos (Specific Pathogen Free - SPF) ou} heteroxênicos: os animais desta categoria sanitária são classificados em "estrelas" segundo a ausência de organismos patogênicos. A classificação de um a cinco estrelas permite o enquadramento dos modelos. Eles são isentos de organismos patogênicos definidos que causam doenças clínicas ou subclínicas ou, ainda, potencialmente patogênicos a uma determinada espécie animal. Esse padrão de saúde dependerá de uma lista individual de exclusão de microrganismo

A criação dos animais é realizada em ambientes protegidos por barreiras sanitárias rigorosas e eficientes ou são alojados em equipamentos que lhes garantam seu padrão microbiológico; os técnicos devem tomar banho; usar uniforme esterilizado toda vez que entrar em áreas onde houver animais bem como, esterilizar por meio de autoclavação, câmara com gás esterilizante ou por solução esterilizante em guichê de passagem de materiais, todos os elementos a serem utilizados, como: peças do vestuário, ração, gaiolas, cama, água, bebedouros e outros.

Gnotobióticos: são animais que possuem microbiota associada definida, sendo criados em ambientes dotados de barreiras sanitárias absolutas. A produção desses animais só é possível por meio de sua manutenção em isoladores.

De acordo com SOUZA \& MERUSSE (1996), a depender da quantidade de microbiotas que esteja associada ao animal, os gnotobióticos podem ser classificados como: 
- Axênico ou "Germfree": são animais totalmente livres de microbiota, isto é, isentos de quaisquer vírus, bactérias, fungos, parasitas internos e externos, protozoários e algas.

- Monoxênico: animal que foi contaminado deliberadamente com apenas um tipo de microbiota.

- Dixênico: animal que foi contaminado deliberadamente com dois tipos de microbiota.

- Polixênico: animal que foi deliberadamente contaminado com vários microbiotas.

- Flora definida: são animais germfree que foram intencionalmente contaminados com microorganismos ou parasitos específicos. São monitorados continuamente para constatar a presença dos organismos selecionados e verificar a ausência de outros (COUTO, 2006).

A Ciência de Animais de Laboratório exerce atualmente um papel de destaque e de fundamental importância para a sociedade, pois a qualidade e a saúde desses animais interferem de modo marcante no resultado de pesquisas, que muitas vezes serão aplicados ao ser humano. Portanto podemos avaliar o significado de falsos resultados em virtude de animais inadequados (VALERO, 1990).

A qualidade começa com a definição do padrão sanitário do animal. $O$ ideal é que os biotérios de criação possuam em suas instalações, barreiras sanitárias e programas de vigilância de saúde que certifiquem que suas colônias são livres de patógenos específicos e quais microorganismos são monitorados (JONAS, 1976; IVIS, 2003 apud MAJEROWICZ, 2005).

\section{3.1 Padrão genético dos animais de laboratório}

A genética é a ciência que estuda os mecanismos da hereditariedade, responsável pela transmissão de características de pais para filhos. Os animais 
de laboratório são "animais genéticos", sendo produtos de uma série de cruzamentos. Cada animal expressa características herdadas do pai e da mãe, podendo também expressar novas características resultantes de mutações na carga genética de um novo indivíduo formado.

Para a formação de um indivíduo deve ocorrer a união dos gametas masculino e feminino formando um zigoto. O novo indivíduo carrega um conjunto completo de cromossomos ou genoma, tendo recebido metade dos cromossomos do pai e a outra metade da mãe. Nos cromossomos estão os genes que determinam as características do indivíduo.

Com o desenvolvimento da genética surgiu o conceito de linhagem pura, ou seja, uma linhagem formada por indivíduos geneticamente idênticos entre si. Para o estabelecimento destas linhagens cruzam-se irmão x irmã por, pelo menos 20 gerações (VALERO et.al, 1990).

Os animais de laboratório podem ser classificados em dois grandes grupos: não-consangüíneos, outbred ou heterogênicos e consangüíneos, inbred ou isogênicos. Aos inbred, foram acrescentados os híbridos, congênicos, mutantes e animais "engenheirados", como, por exemplo, os transgênicos.

Os animais não-consangüíneos ou outbred apresentam na constituição genética uma alta heterozigose (99\%), o que faz que seja mantida em uma mesma colônia uma grande diversidade genética (vários alelos), tornando possível a reprodução de populações naturais.

Um animal consangüíneo ou inbred é o produto de 20 gerações consecutivas do acasalamento entre irmãos, ou pais e filhos. Com esse tipo de acasalamento, consegue-se obter um índice de homozigose de 99\%, tornando tais animais os mais idênticos possíveis que se pode obter (SANTOS, 2006).

Animais transgênicos são aqueles cujo genoma foi modificado pela introdução de sequências de DNA de outro organismo. Muitas vezes tais 
sequências são manipuladas por engenharia genética de tal forma que constituem uma mistura de pedaços de DNA vindo de diversas origens (ABDELHAY, 2006).

As características genéticas são importantes no que se refere à seleção e ao manejo dos animais para uso em colônias de reprodução e em pesquisa biomédica. A variabilidade genética pode ser monitorada por meio de simulações computadorizadas, marcadores bioquímicos, marcadores de DNA, marcadores imunológicos ou análises genéticas quantitativas de variáveis fisiológicas. $O$ caráter homozigoto desses animais aumenta as chances de reprodução e de comparação de alguns dados experimentais (NRC, 2003).

\section{III.3.2 Importância das patologias dos animais de laboratório}

Zoonoses são doenças transmitidas naturalmente dos animais ao homem e seu controle é fundamental nos biotérios, pois algumas doenças podem representar perigo na saúde dos profissionais que trabalham nessa área (TAB. 1).

Agentes microbianos patogênicos presentes nas colônias de animais de laboratório freqüentemente têm sido responsabilizados por causar: alterações de resultados experimentais e erro de interpretação dos mesmos, mortes de animais na colônia, contaminação de material biológico, como soros e vacinas, e doenças transmissíveis ao homem (GILIOLI, 1996).

Basicamente, o manejo de animais oferece aos humanos, dois tipos de risco: de infecção e traumático (por agressão), podendo levar ao risco infeccioso. Os animais podem excretar microorganismos nas fezes, urina, saliva ou aerolizálos, originando, infecções.

Existe ainda a possibilidade de inoculação de patógenos por mordidas ou arranhões, assim como a transmissão direta, por contato com o animal, seu sangue ou tecidos coletados em necropsias e autópsias; e indireta, por inalação de poeira originada das gaiolas e camas dos animais (CARDOSO, 1998). 
TABELA 1 - Principais zoonoses.

\begin{tabular}{|c|c|c|c|c|}
\hline $\begin{array}{c}\text { Nome da } \\
\text { doença }\end{array}$ & Agente & Hospedeiro & Transmissão & Vetores \\
\hline $\begin{array}{l}\text { Coriomeningite } \\
\text { linfocitária }\end{array}$ & LCM & Roedores & $\begin{array}{l}\text { Contato, inalação, } \\
\text { transmissão } \\
\text { congênita e cultura } \\
\text { de tecidos }\end{array}$ & \\
\hline Criptosporidiose & Cryptosporidium sp & Mamíferos & $\begin{array}{l}\text { Inalação e contato } \\
\text { com fezes }\end{array}$ & \\
\hline Dermatomicoses & $\begin{array}{l}\text { Trychophytum spp } \\
\text { Microsporum sp } \\
\text { Dermatophytes spp }\end{array}$ & $\begin{array}{l}\text { Roedores e } \\
\text { lagomorfos }\end{array}$ & Contato direto & \\
\hline Febre hemorrágica & $\begin{array}{l}\text { Vírus da febre } \\
\text { hemorrágica }\end{array}$ & $\begin{array}{l}\text { Roedores } \\
\text { silvestres }\end{array}$ & $\begin{array}{l}\text { Contato e comida } \\
\text { contaminada com } \\
\text { excretas }\end{array}$ & \\
\hline $\begin{array}{l}\text { Febre por } \\
\text { mordidas de rato }\end{array}$ & $\begin{array}{l}\text { S. Moniliformis } \\
\text { Spiriliumminus }\end{array}$ & Roedores & $\begin{array}{l}\text { Mordidas por } \\
\text { roedores e } \\
\text { ingestão }\end{array}$ & \\
\hline Hantavirose & $\begin{array}{l}\text { Vírus da família } \\
\text { Bunyviridae }\end{array}$ & $\begin{array}{l}\text { Ratos } \\
\text { silvestres }\end{array}$ & $\begin{array}{l}\text { Inalação, urina e } \\
\text { fezes }\end{array}$ & \\
\hline Lepstopirose & Lepstopira spp & Roedores & $\begin{array}{l}\text { Contato, urina e } \\
\text { água contaminada. }\end{array}$ & $\begin{array}{l}\text { Artrópodes } \\
\text { sugadores de } \\
\text { sangue }\end{array}$ \\
\hline Toxoplasmose & Toxoplasma gondii & $\begin{array}{l}\text { Todos os } \\
\text { animais } \\
\text { convencionais }\end{array}$ & $\begin{array}{l}\text { Ingestão de } \\
\text { oocistos, inalação e } \\
\text { transmissão fetal }\end{array}$ & \\
\hline Listeriose & Listeria monocytogenes & $\begin{array}{l}\text { Roedores e } \\
\text { lagomorfos }\end{array}$ & $\begin{array}{l}\text { Contato com fezes, } \\
\text { fetos abortados e } \\
\text { restos placentários }\end{array}$ & \\
\hline Peste & P. pestis & Roedores & Contato, inalação & Pulgas \\
\hline Pneumonia & B. bronchiseptica & $\begin{array}{l}\text { Roedores e } \\
\text { lagomorfos }\end{array}$ & Contato e inalação & \\
\hline $\begin{array}{l}\text { Protozoonoses } \\
\text { sanguíneas }\end{array}$ & $\begin{array}{l}\text { Trypanosoma spp } \\
\text { Plasmodium spp } \\
\text { Leishmania spp }\end{array}$ & Roedores & Saliva contaminada & Insetos sugadores \\
\hline Pseudotuberculose & P. pseudo tuberculosis & Roedores & Contato e ingestão & \\
\hline Raiva & Vírus rábico & Mamíferos & Por mordidas & Saliva contaminada \\
\hline Ricketsioses & R. akari & Camundongos & Por picadas & $\begin{array}{l}\text { Allodenmanyssus } \\
\text { sanguineus }\end{array}$ \\
\hline Ricketsioses & R. richesia & $\begin{array}{l}\text { Roedores e } \\
\text { lagomorfos }\end{array}$ & Por picadas & Denmacentor spp \\
\hline Ricketsioses & R. mosseri & $\begin{array}{l}\text { Ratos e } \\
\text { camundongos }\end{array}$ & Por picadas & Pulgas e piolhos \\
\hline Salmonelose & Salmonela spp & $\begin{array}{l}\text { Animais em } \\
\text { geral }\end{array}$ & $\begin{array}{l}\text { Ingestão, inalação } \\
\text { e contato }\end{array}$ & \\
\hline Tularemia & F. tularensis & $\begin{array}{l}\text { Lagomorfos e } \\
\text { roedores } \\
\text { silvestres }\end{array}$ & Contato e ingestão & $\begin{array}{l}\text { Insetos sugadores } \\
\text { e ácaros }\end{array}$ \\
\hline bactéria & vírus & sias & ngos e protozor & Os \\
\hline
\end{tabular}

KIMURA, (2002)), MEZADRI et al., 2004). 
Existem quatro vias que podem funcionar como porta de entrada de agentes infecciosos no organismo:

- Aérea: através de aerossóis, podendo a infecção ser amplamente difundida, pela facilidade que esse veículo oferece ao transporte da doença;

- Cutânea: através das unhas dos animais e homens quando contaminadas, de objetos ou instrumentos perfurocortantes contaminados ou por meio de ferimentos;

- Oral: acontece por falta de higiene pessoal e negligência no cumprimento dos procedimentos operacionais;

- Ocular: a contaminação se dá através da mucosa conjuntiva, via gotículas ou aerossóis de material infectante diretamente nos olhos.

Podemos minimizar ou eliminar o risco de enfermidades transmitidas entre homens e animais com o cumprimento rigoroso dos procedimentos operacionais padronizados, destinados a garantir a segurança para ambos, como por exemplo: a realização de exames médicos periódicos para as pessoas que manipulam animais e o controle sanitário dos animais.

\section{III.3.3 Quarentena}

No recebimento de novos animais, o risco de introdução de uma infecção em colônias de roedores é sempre muito elevado, em razão do "spread". Um único animal infectado pode causar uma doença epidêmica, ocasionando perda de tempo e prejudicando os resultados da pesquisa, uma vez que a eliminação da contaminação de um patógeno no biotério é um processo caro e demorado. Para a realização de determinados projetos ou pesquisas, a introdução de novos animais é imprescindível, sendo necessário minimizar os riscos por meio de exames do padrão de saúde para todos os novos animais ((IVIS, 2003) apud MAJEROWICZ, 2005). 
A origem dos animais é considerada de grande importância na segurança do padrão microbiológico dos animais e no ambiente do biotério. Como a certificação sanitária, apresentada pelo fornecedor, nem sempre é garantia para se obter total segurança, a quarentena é fundamental nas situações em que o padrão microbiológico de novos animais pode ocasionar danos à saúde dos outros residentes e dos indivíduos envolvidos no ambiente do biotério ((REHG\&TOHT, 1998) apud MAJEROWICZ, 2005).

A quarentena é a separação de animais recém-adquiridos daqueles que já se encontram nas instalações até que se determine o estado de saúde e, possivelmente, o perfil microbiológico dos animais recém-adquiridos. Quando se aplica uma quarentena eficiente, reduzem-se consideravelmente as chances de introdução de patógenos numa colônia estável. O período da adaptação dependerá do tipo e do tempo de transporte dos animais, da espécie envolvida e do uso pretendido dos animais (NRC, 2003).

Geralmente, essa separação é feita pelo alojamento das diferentes espécies em salas separadas, cubículos, unidades de fluxo laminar, gaiolas que possuem ar filtrado ou ventilação separada e isoladores. Também é recomendada a separação física dos animais por espécie, para evitar a transmissão interespecífica (que ocorre entre indivíduos de espécies diferentes) de doenças e eliminar a ansiedade e possíveis alterações fisiológicas e comportamentais ocasionadas por conflitos entre as espécies (NRC, 2003).

Os materiais biológicos, principalmente de origem externa, devem ser considerados de grande importância na segurança microbiológica dos animais, técnicos e ambientes em biotérios, devendo ser monitorados, para prevenir a introdução de agentes transmissíveis que possam influenciar na saúde humana, devido aos agentes zoonóticos, de outros animais ou resultados da própria experimentação animal ((SMALL, 1984; FELASA, 1996) apud MAJEROWICZ, 2005). 
Um fator determinante, para que os riscos de contaminação sejam minimizados, é criar barreiras sanitárias eficientes, com tipos de acesso diversos ou independentes, para evitar a introdução de organismos indesejáveis (vírus, fungos, bactérias, parasitos), infecções, para garantir a saúde do animal e o bemestar dos operadores que trabalham no biotério ((FELASA, 1996) apud MAJEROWICZ, 2005).

As dependências destinadas à quarentena podem ser instalações simples, garantindo o perfeito isolamento dos animais, com higienização e desinfecção rápida e eficaz, e também, facilidade para recolhimento e destruição de cadáveres e dejetos.

Um cuidado essencial é a adoção, sempre que possível, da segregação de materiais e do acesso, além de um programa de Recursos Humanos, de tal forma que os técnicos deste setor não atuem em outras áreas da unidade, principalmente nos setores de Fundação e matrizes.

\section{III.3.4 Princípios éticos para o uso dos animais de laboratório}

A ética é a ciência da moral e tem relação com o certo e o errado; é uma atitude cultural, crítica, sobre valores e posições de relevância no momento de atuar. Os conflitos existentes entre as tentativas de resolver situações de vital importância e os princípios éticos de respeito à vida, a abstinência de infligir dor e sofrimento, ocasionam um problema ético do uso de animais para experimentação (RIVERA, 2006).

A senciência em um animal significa que ele tem capacidade de sentir e que ele se importa com o que sente, ou seja, o animal é capaz de sentir dor e querer que ela acabe. Os animais sencientes interpretam as sensações e informações que recebem do ambiente por meio de cognição (razão) e emoções. A senciência é uma reação mais emocional do que cognitiva às sensações, ou seja, o animal tem entre outras coisas, afeição à prole, medo de ser atacado, repulsa ao tédio e aversão ao isolamento. Portanto, devemos reconhecer que, em 
termos éticos, os animais são como seres sensíveis, portadores de valores de alguma importância moral e que devem ser respeitados (NACONECY, 2006).

Por volta de 1860, ocorreu um fato importante para determinar limites éticos quanto à utilização de animais em experimentação, envolvendo a esposa $\mathrm{e}$ a filha do fisiologista Claude Bernard, por ter usado o cão de estimação de sua filha para dar aulas práticas aos seus alunos. Foi criada por sua esposa, na França, em resposta a essa ação, a primeira associação em defesa dos animais de laboratório (MEZADRI; TOMÁZ; AMARAL, 2004).

Os animais para experiência mais usados nos biotérios, como cobaias, ratos, camundongos e coelhos, são animais capazes de sofrer, sentir dor, medo e estresse. Portanto, é fundamental ter uma postura ética, não deixando que esses animais sejam desrespeitados. Deve haver uma preocupação com o seu bemestar, evitando que passem desnecessariamente por estresse e minimizando o sofrimento que possamos causar-Ihes.

Para a utilização de animais com mais ética, Russell \& Burch (1959), dois cientistas ingleses, conseguiram resumir com três palavras o Princípio Humanitário da Experimentação Animal, palavras iniciadas com a letra $\mathrm{R}$ em inglês - Replacement, Reduction e Refinement - conhecido como o Princípio dos três Rs (RIVERA, 2006).

Replacement - traduzido como "Alternativas/Substituição", indica que sempre que possível, no lugar de animais vivos, sejam usados materiais sem sensibilidade, como cultura de tecidos, modelos em computador e outros. Algumas áreas ainda não utilizam este princípio, não tendo sido descoberto um método que substituísse os animais, como, por exemplo, pesquisas que avaliam comportamento, dor, cirurgias experimentais e ação de drogas.

Reduction - traduzido como "Redução", nesse caso, onde o uso de animais é inevitável, indica que devemos utilizar o menor número possível de animais em experimentos ou atividades práticas de ensino, apenas a quantidade necessária para fornecer resultados estatísticos significativos. Atualmente, devido à utilização 
de animais com estado sanitário e genético conhecidos, com o delineamento experimental e a análise estatística antes do início da pesquisa ou testes, o número de animais usados em experimentação diminuiu. Outro fator importante é a participação de pessoas preocupadas com a ética na atividade de pesquisa com uso de animais, que têm contribuído de maneira positiva nessa área, ministrando cursos sobre animais de laboratório, ensinando como usar o menor número possível de animais e fazendo com que o bom senso, o respeito e a ética prevaleçam.

Refinement - traduzido como "Aprimoramento/Refinamento", indica a utilização de materiais e técnicas menos invasivas. Somente pessoas bem treinadas devem manusear animais, pois uma simples injeção pode causar muita dor, caso seja aplicada por pessoa inexperiente. Procedimentos ou protocolos experimentais devem ser empregados para minimizar a dor e o estresse, promovendo o bemestar animal. Fatores que levam as mudanças fisiológicas podem interferir de maneira significativa, nos resultados do experimento.

O Colégio Brasileiro de Experimentação Animal (COBEA), hoje denominado Sociedade Brasileira de Ciência em Animais de Laboratório SBCAL, filiado ao International Council for Laboratory Animal Sciense - ICLAS é uma sociedade civil de caráter científico-cultural, sem fins lucrativos, composta por pesquisadores e técnicos interessados em experimentação animal que criou, em 1991, os Princípios Éticos na Experimentação Animal, postulando 12 artigos que passaram a conduzir a conduta dos pesquisadores na prática do uso de animais. Alguns objetivos destes princípios são (CRISSIUMA; ALMEIDA, 2006):

- Planejar e executar procedimentos baseados na sua importância para a saúde humana e animal, a aquisição de conhecimentos ou o bem da sociedade;

- Estabelecer o propósito do experimento;

- Usar espécie, qualidade e número de animais apropriados;

- Prevenir ou evitar o desconforto, a angústia e a dor conforme os princípios da boa ciência; 
- Usar sedação, analgesia ou anestesia adequada nos procedimentos que possam causar dor ou angústia;

- Proporcionar manejo adequado para os animais, dirigido e executado por pessoas experientes;

- Realização de procedimentos em animais vivos efetuadas por pessoas experientes e qualificadas.

Segundo RIVERA (1996): "É na educação e consciência de cada indivíduo que trabalha com animais que deve estar incutido o princípio de minimizar a utilização da dor, o sofrimento e o estresse dos animais" (MEZADRI et al., 2004).

É fundamental, que na implantação de um biotério, haja preocupação em atender e seguir os artigos dos Princípios Éticos na Experimentação Animal, para que, na busca do conhecimento, não haja desrespeito aos animais, que os procedimentos que possam causar dor ou angústia possam ser desenvolvidos de maneira adequada, que o alojamento seja apropriado para o seu bem-estar e que recebam proteção e tratamento humanitário por parte dos pesquisadores, funcionários e operadores do biotério. Por outro lado, cabe lembrar, que a experimentação animal ainda é insubstituível nas pesquisas médicas e veterinárias, proporcionando um avanço nas novas descobertas, gerando conhecimento e produzindo tecnologias para o bem-estar e saúde da sociedade (JC, 2007).

A preocupação com o bem-estar animal e com a proteção das pessoas que desenvolvem trabalhos científicos utilizando animais fez com que surgissem leis referentes à experimentação animal e a criação de Comitês de Ética em Pesquisa Animal. Os Comitês de Ética são considerados como um dos melhores sistemas de orientação e de controle sobre cuidado e uso de animais de laboratório. Eles auxiliam a comunidade científica a colocar restrições ao uso indiscriminado de animais em ensino, pesquisa e testes, pois leva em consideração não só a relevância do desenvolvimento da ciência, mas também considera como relevante o bem-estar dos animais utilizados. 
Outro papel importante destes comitês é o de conscientizar as pessoas envolvidas sobre o conteúdo ético que envolve a pesquisa com animais e a ponderar antes de iniciar seus trabalhos. Um Comitê de Ética deve auxiliar os pesquisadores e outras pessoas a desfazerem suas dúvidas e a conhecerem seus deveres para com os animais, elaborar normas, estabelecer freqüência de reuniões, atas, registros e outros procedimentos que forem considerados necessários. Também desempenham papel importante ajudando a educar e fazendo com que cada indivíduo adquira consciência de que trabalha com seres com sensibilidade e procure ter imbuído o princípio de consideração para todo e qualquer ser vivo (RIVERA, 2006).

\section{III.3.5 Estresse e bem-estar dos animais de laboratórios}

Em 1872, o cientista inglês Charles Darwin estabeleceu que diferentes tipos de estímulos externos provocariam uma resposta orgânica similar. Em 1929, Cannon fez esta colocação de forma mais científica, e caracterizou o estresse como uma resposta fisiológica produzida pelo aumento da atividade do sistema nervoso simpático. Essa alteração seria a mesma para excitação, fome, dor e medo (LUNA, 2006).

Estresse é o conjunto de reações do organismo a agressões de ordem física, psíquica, infecciosa e outras capazes de perturbar a homeostase, ou seja, o equilíbrio fisiológico normal do corpo. Fatores que implicam em estresse agem como variáveis sobre o animal utilizado pelo pesquisador, dando margem a questionamentos quanto à confiabilidade dos resultados da sua pesquisa (MEZADRI; TOMÁZ; AMARAL, 2004).

A natureza do estresse em animais de experimentação é, primariamente, emocional ou psicológica, onde muitas situações, que parecem comuns para o homem, são estressantes para os animais de experimentação. RIVERA (2006) relata que o estresse psicológico pode ser causado por várias condições, tais como: 
- novidades (modificações ambientais, presença de pessoas que habitualmente não fazem parte do ambiente do animal);

- estímulos indutores do medo (ruídos, contenção física);

- fatores sociais (superpopulação nos alojamentos, animais novos inseridos no microambiente e isolamento);

- incapacidade de realizar padrões normais de comportamento (restrições físicas induzidas, modificação de luminosidade, dificuldade de acesso à comida e à água);

- causas de dor, desconforto e doença;

- antecipação de dor e desconforto;

- manejos inadequados que levem à frustração ou ao conflito.

O controle e a previsão são termos importantes em estresse. Poder controlar, ou não, a situação de estresse, depende dos mecanismos dos quais o animal dispõe para lidar com o desafio, e da atitude que cada indivíduo tem sobre a situação. Quando a situação for considerada de perigo para a homeostase, são ativados mecanismos para controlar ou conviver com a mesma (RIVERA, 2006).

Segundo Quimby (1991), "distress é um estado emocional onde o animal fica impossibilitado de se adaptar adquirindo comportamento considerado alterado para sua espécie" (FEIJÓ, 2005). A idéia de distress está muito ligada à evolução do conceito de estresse. Os diferentes fatores estressantes poderiam induzir formas benéficas e/ou danosas de estresse (eustress e distress, respectivamente). A incapacidade para superar a vivência de experiências estressantes desgasta o indivíduo, levando a uma ruptura do bem-estar individual, o que constituiria o distress (SPARRENBERGER; SANTOS; LIMA, 2003).

A evolução da ciência e os constantes questionamentos sobre o uso de animais de experimentação científica mudaram as relações entre o ser humano e os animais, transformando o bem-estar animal em uma importante área de estudo, pois pode influenciar o resultado de um experimento. $O$ primeiro passo para conseguir um grau elevado de bem-estar para os animais é por meio da educação, treinamento das pessoas, conscientização da necessidade de tratá-los 
com dignidade e atitudes de respeito. Vários fatores, físicos, químicos ou microbiológicos podem iniciar um desequilíbrio fisiológico nos animais e conseqüentemente aumentar ou diminuir o bem-estar, principalmente pela situação de confinamento e impossibilidade de resolver situações indesejáveis (FIG. 1). É necessário um ambiente adequado para manutenção de animais de laboratório, pois essas espécies são sensíveis a fatores internos e externos (FRAJBLAT, 2008).

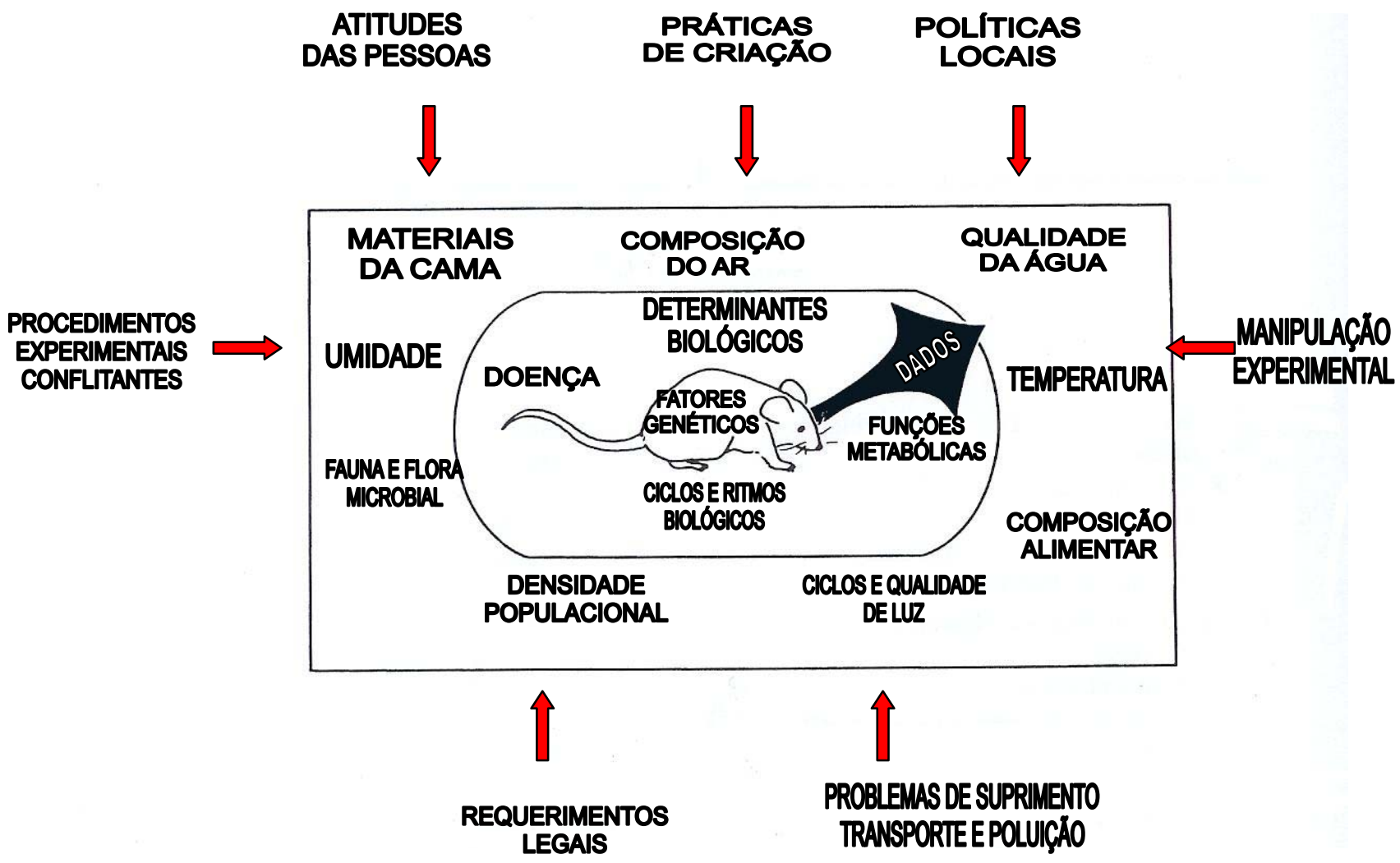

FIGURA 1 - Fatores ambientais e de gerenciamento que afetam a homeostase animal (RUYS, 1991).

Pode-se definir o estado de bem-estar de um determinado animal considerando-se três situações, distintas, mas que se completam (COSTA; PINTO, 2006):

- Estado psicológico do animal - O bem-estar é definido em função dos sentimentos e emoções dos animais, conseqüentemente, animais com medo, frustração e ansiedade enfrentariam problemas de bem-estar; 
- Funcionamento biológico do animal - Devem-se manter em equilíbrio as funções orgânicas dos animais, com condições de crescer e se reproduzir normalmente, livre de doenças, injúrias e sem sinais de desnutrição, além de não apresentarem comportamentos e respostas fisiológicas anormais;

- Vida natural - Os animais deveriam ser mantidos em ambientes semelhantes ao seu habitat, com liberdade para desenvolver suas características e capacidades naturais.

A Declaração de Política de Proteção, Bem-Estar e Etologia dos Animais, elaborada pela Associação Mundial de Veterinária, em maio de 1989, tem um item importante que trata da experimentação animal e confirma os princípios da Sociedade Brasileira de Ciência em Animais de Laboratório - SBCAL. As experimentações que utilizam animais são, em alguns casos, inevitáveis, portanto, o número de animais utilizados deve ser mínimo, e todo e qualquer esforço deverá ser feito no sentido de descobrir e utilizar alternativas à experimentação, além do constante empenho para criar condições favoráveis em alojamento (MEZADRI; TOMÁZ; AMARAL, 2004).

$\mathrm{Na}$ área do alojamento, o espaço suficiente para a realização de movimentos corporais normais, o livre acesso à água e alimento, são requisitos fundamentais para as necessidades básicas do animal. $O$ estresse decorrente por excesso de animais confinados ou 0 isolamento pode causar alterações fisiológicas e comportamentais, que com certeza, irão interferir na resposta ao experimento (FRAJBLAT; AMARAL; RIVERA, 2008).

Segundo Dr. Charles Hume (UFAW: Universities Federation for Animals Welfare): "o que o bem-estar animal precisa é de pessoas com conhecimento, cabeça fria e coração quente, sensíveis ao sofrimento animal e procurando meios práticos de aliviá-los". Cabe salientar que o bem-estar dos animais de laboratório é fundamental não apenas para os animais, mas para garantir a credibilidade dos resultados das pesquisas, uma vez que animais em condições físicas e psicológicas inadequadas podem provocar alterações nesses resultados (RIVERA, 1990). 
O desenvolvimento da ciência a favor do homem não pode nem deve servir de base para o uso indiscriminado e o desrespeito com os animais. É preciso uma postura ética frente à necessidade do desenvolvimento da ciência, adotando medidas que diminuam o sofrimento dos animais e beneficiem seu bem-estar. A confiabilidade do resultado da pesquisa depende do bem-estar vivido pelo animal durante sua realização, da compreensão e sensibilidade do pesquisador para o entendimento de seus sofrimentos e necessidades, e do bom senso nas tomadas de decisão e atitudes (FRAJBLAT; AMARAL; RIVERA, 2008)

\section{III.4 Biossegurança}

O profissional de saúde está freqüentemente exposto a riscos biológicos e de produtos químicos. O imprevisível e diversificado comportamento das doenças infecciosas emergentes e re-emergentes tem causado a discussão das condições de biossegurança nas Instituições de pesquisa, ensino, desenvolvimento tecnológico e de prestação de serviços. O manejo e a avaliação de riscos são fundamentais para a definição de critérios e ações, e visam a reduzir os riscos que podem colocar em perigo a saúde do homem, dos animais, do meio ambiente ou a qualidade dos trabalhos desenvolvidos.

As infecções adquiridas em um laboratório têm sido descritas por meio da história da microbiologia. Os relatórios de microbiologia publicados na virada do século descreveram casos de tifo, cólera, mormo, brucelose e tétano associados a laboratórios. Meyer e Eddie (1941) publicaram uma pesquisa de 74 casos de brucelose, associados a laboratório, ocorridos nos Estados Unidos e concluíram que "a manipulação de culturas ou espécies e a inalação da poeira contendo a bactéria Brucella são altamente perigosas para os trabalhadores de um laboratório". Sulkin e Pike (1949) constataram 222 infecções virais, sendo 21 delas fatais, em pesquisas sobre infecções associadas a laboratórios, sendo que em um terço dos casos, a provável fonte de infecção estava associada ao manuseio de animais e tecidos infectados (BRASIL, 2004). 
A biossegurança no Brasil estava formatada legalmente para os processos envolvendo organismos geneticamente modificados (OGM), de acordo com a Lei de Biossegurança - $\mathrm{n}^{\circ} 8.974$, de 5 de janeiro de 1995, regulamentada pelo Decreto $n^{\circ} 1752$, marcando mudanças significativas nessa área, principalmente com a criação da Comissão Técnica Nacional de Biossegurança (CTNBio). Esta Comissão estabeleceu Normas e Instruções Normativas para todos os níveis de atuação, como hospitalar, ambulatorial, laboratórios, nas indústrias e áreas voltadas pára a pesquisa, que cita no seu art. $1^{\circ}$ (COSTA, 2000).

Essa lei foi revogada e hoje a lei que trata a biossegurança no Brasil é a Lei $N^{\circ}$ 11.105, de 24 de março de 2005, cria o Conselho Nacional de Biossegurança (CNBS), reestrutura a Comissão Técnica Nacional de Biossegurança (CTNBio) e dispõe sobre a Política Nacional de Biossegurança (PNB) (BRASIL, 2005).

"Esta lei estabelece normas de segurança e mecanismos de fiscalização sobre a construção, cultivo, produção, manipulação, transporte, transferência, importação, exportação, armazenamento, pesquisa, comercialização, consumo, liberação no meio ambiente e descarte de organismos geneticamente modificados (OGM), visando a proteger a vida e a saúde do homem, dos animais e das plantas, bem como o meio ambiente."

$\mathrm{Na}$ década de 70, o foco de atenção voltava-se para a saúde do trabalhador frente aos riscos biológicos no ambiente ocupacional. Conforme a Organização Mundial de Saúde (WHO, 1993) "as práticas preventivas para o trabalho em contenção em nível laboratorial, com agentes patogênicos para o homem". A própria (WHO,1993), na década de 80, incorporou a essa definição os chamados riscos periféricos presentes em ambientes laboratoriais que trabalhavam com agentes patogênicos para o homem, como os riscos químicos, físicos, radioativos e ergonômicos. Nos anos 90, a definição de biossegurança sofreu mudanças significativas (COSTA, 2000). A Portaria $n^{\circ} 228$, de 28 de abril de 1998, do Ministério do Exército (Valle, 1998) diz que: 
"Biossegurança é o conjunto de ações voltadas para a prevenção, minimização ou eliminação de riscos inerentes às atividades de pesquisa, produção, ensino, desenvolvimento tecnológico e de prestação de serviços, visando à saúde do homem, dos animais, a preservação do meio ambiente ou a qualidade dos trabalhos desenvolvidos".

Nos laboratórios de pesquisa e criação, os riscos biológicos são inúmeros para aqueles que realizam tal atividade. É fundamental que os profissionais que atuam nessa área, adotem procedimentos rígidos de Normas de Biossegurança, tendo consciência dos perigos existentes e conhecimento dos riscos aos quais estão expostos.

O desenvolvimento tecnológico, o progresso científico e o rigor das legislações vêm contribuindo de forma sistemática, para a redução dos acidentes laboratoriais. Mesmo sabendo que o risco zero é uma meta utópica, temos que buscar métodos que reduzam e previnam os acidentes, sendo importante (COSTA, 2000):

- Desenvolver no ambiente de trabalho a cultura da biossegurança;

- Avaliar a biossegurança, no contexto global da instituição, como ocorre com os processos da qualidade;

- Aplicar, de forma planejada, as ferramentas da qualidade para a avaliação e correção do sistema de biossegurança.

Os perigos podem ser minimizados ou eliminados com o estrito cumprimento de procedimentos operacionais padronizados destinados a garantir a segurança, contribuindo para um meio de trabalho mais seguro e saudável para a equipe de laboratório, seus colaboradores e a comunidade ao redor. 


\section{III.4.1 Barreira sanitária e de contenção}

Em Biotérios, o Sistema de Barreiras é complexo e se inicia na concepção da unidade. Para a instalação de um sistema bem sucedido, as barreiras devem ser consideradas inicialmente com as seguintes necessidades:

- Conhecimento das finalidades dos modelos animais que serão mantidos/produzidos.

- Fornecimento, relacionado ao número de animais, espécie, linhagem, sexo, freqüência e periodicidade.

Em seguida, deve ser considerado o desenho arquitetônico, com a distribuição das áreas, fluxos de materiais e procedimentos, compatibilização das atividades e finalmente os detalhes de materiais empregados e equipamentos. Também é indispensável que se considere a formação e capacitação de RH como parte do sistema de barreiras.

A finalidade das barreiras sanitárias e de contenção é impedir que agentes indesejáveis tenham acesso às áreas de criação animal ou de experimentação animal e que agentes patogênicos venham a se disseminar no ambiente de trabalho ou para o ambiente externo do prédio, assegurando a qualidade dos dados da pesquisa científica e o bem-estar dos profissionais que atuam nessa área. Com o objetivo de minimizar, ou impedir, a introdução de agentes indesejáveis ao biotério, devemos ter pelo menos as seguintes condições:

- O menor número de acessos, impedindo com isso a entrada de animais e insetos, eventuais portadores de doenças.

- Sistema de condicionamento de ar adequado às exigências das espécies animais, assegurando a filtração do ar e evitando a contaminação de áreas vizinhas.

- Desinfecção freqüente das superfícies, principalmente dos pisos.

- Esterilização ou desinfecção e estocagem adequada dos materiais e outros insumos vindos do exterior. 
- Utilização de sistemas sifonados, se possível com fechamento, enquanto a drenagem de efluentes não estiver em uso

A palavra contenção é usada para descrever os métodos de segurança utilizados na manipulação de materiais infecciosos em um meio laboratorial onde estão sendo manejados ou mantidos. A contenção tem como objetivo, reduzir ou eliminar a exposição da equipe de um laboratório, de outras pessoas e do meio ambiente em geral aos agentes potencialmente perigosos (BRASIL, 2004). As barreiras de contenção nos biotérios são imprescindíveis, já que o risco de contaminação é considerado freqüente, em função das atividades desenvolvidas.

A contenção primária consiste da proteção individual e do laboratório diante de um agente infeccioso e se efetiva pela aplicação de técnicas laboratoriais e com o uso de Equipamentos de Proteção Individual (EPI) e/ou Equipamentos de Proteção Coletiva (EPC). Os EPI são dispositivos de uso pessoal, destinados a proteção da saúde e integridade física do trabalhador. $\mathrm{O}$ uso dos EPI no Brasil é regulamentado pela Norma Regulamentadora NR-6 da Portaria 3214 de 1978, do Ministério do Trabalho e Emprego. Os EPC auxiliam na segurança do trabalhador dos serviços de saúde e laboratórios, na proteção ambiental e na pesquisa desenvolvida. Já a contenção secundária refere-se à utilização de edificações e instalações laboratoriais adequadas, proteção das áreas externas ao laboratório de uma contaminação do agente em uso, sendo conferida pelas instalações, sistemas de utilidades prediais e métodos operacionais. As instalações, itens de segurança individual e coletivo, possibilitam eliminar ou diminuir os riscos associados a um determinado agente de risco (MAJEROWICZ, 2008).

Alguns dos principais equipamentos de segurança, individual e/ou coletivo, utilizados nos biotérios para eliminar ou diminuir exposições aos agentes de riscos são (MEZADRI et al., 2004; MOLINARO et al., 2008; FIOCRUZ, 1994; BARBOZA, 2001; SILVA, 2009):

- Equipamentos de proteção individual (EPI) - têm como objetivo amenizar ou eliminar riscos de infecção como: jalecos - protegem a 
parte superior e inferior do corpo, reduz a transmissão de contaminação das roupas e protege a pele da exposição ao derrame de material infectado; luvas - evitam a transmissão de microorganismos presentes nas mãos e protege o trabalhador de queimaduras químicas, calor ou frio extremo, mordidas, cortes e arranhões provocados por animais; óculos de segurança e máscara facial - para proteção contra salpicos, borrifos, gotas de sangue, material infectante e risco de impacto de fragmentos sólidos; máscaras ou respiradores - para proteger às mucosas nasais e bucais; toucas ou gorros - evitam acidentes e contaminações por microorganismos e poeiras em suspensão e protetores auriculares - usados para trabalhos em locais onde o nível de ruído for superior ao estabelecido.

- Autoclave - utilizado na esterilização de materiais e insumos. Deve ter porta dupla, com intertravamento das mesmas, impedindo a comunicação entre as áreas "séptica "e "asséptica". Esse equipamento utiliza o método de calor úmido (vapor) e pressão para esterilização. Gaiolas plásticas, tampas de gaiolas, bicos, "cama”, uniformes e rações são alguns materiais normalmente autoclaváveis.

- Estufa de esterilização - o método de esterilização é por calor seco, que oxida as proteínas. O calor sem pressão tem menor poder de penetração, portanto, é menos eficaz que a autoclave.

- Filtros - tem a finalidade de reter materiais ou substâncias indesejáveis. Os filtros de ar retiram as impurezas do ar ambiente e, dependendo da sua porosidade podem reter microorganismos em suspensão no ar. Geralmente, esses filtros fazem parte do sistema de ventilação.

- Tanque de imersão - barreira química onde as áreas sépticas e assépticas têm comunicação, portanto, o tanque deve ser construído de maneira que o nível de solução desinfetante impeça a comunicação direta entre os dois ambientes.

- Pass through - também chamadas trampas ou caixas de passagem. Tem a finalidade de limitar a movimentação de pessoas no interior das áreas limpas ou também para separar as operações sujas. Possui duas 
portas com intertravamento que permite a abertura de uma porta por vez, evitando com isso, o contato entre dois ambientes.

- Air-lock - pequeno ambiente com pressão positiva ou negativa, com a finalidade de impedir a entrada ou a saída de ar de um ambiente para outro.

- Cabine de Segurança Biológica (CSB) - Os aerossóis são uma fonte importante de infecção, devemos evitar ao máximo a sua formação e dispersão. A CSB é utilizada para proteção do trabalhador e do meio ambiente de exposição aos aerossóis que possam ser gerados durante a manipulação de agentes infecciosos, tais como: manuseio de fluídos ou tecidos, ovos de animais infectados ou a necropsia de animais infectados.

- Isoladores - permite a realização de ensaios exclusivos, segurança ao ambiente e as pessoas que trabalham com animais. Os isoladores garantem a manutenção do padrão sanitário e genético das linhagens, atuando como repositório.

- Caixa descartável para perfurocortante - seringas, agulhas e bisturis.

- Sinalização laboratorial - conjunto de símbolos com cores e formas diferenciadas indicando sinalização de aviso, interdição, obrigação, segurança, prevenção de incêndio, símbolo de Risco Biológico, Risco Químico, Risco Radioativo e outros.

O termo risco quer dizer a probabilidade que um dano, um ferimento ou uma doença ocorra. A avaliação do risco se concentra na prevenção de infecções relacionadas aos laboratórios, é um exercício essencial e produtivo, auxiliando na designação dos níveis de biossegurança (instalações, equipamentos e práticas) que irão reduzir, para um risco mínimo, a exposição de trabalhadores e do meio ambiente a um agente perigoso (BRASIL, 2004).

Desde 1997, o Brasil, possui uma classificação dos "agentes etológicos humanos e animais com base no risco apresentado" (Instrução $n^{\circ} 7$, da CTNBio, de 09/06/97), que foi atualizada pela Comissão de Biossegurança em Saúde do Ministério da Saúde ((MINISTÉRIO DA SAÚDE, 2004) CARDOSO apud MOLINARO et al., 2008). 
Segundo essa classificação, os agentes biológicos são divididos em quatro classes de risco, apresentadas a seguir:

- Classe de risco 1 (baixo risco individual e para a coletividade): estão incluídos os agentes conhecidos por não causarem doenças em pessoas ou animais adultos sadios. Exemplo: lactobacillus

- Classe de risco 2 (moderado risco individual e limitado risco para a comunidade): nesse caso, inclui os agentes de risco moderado, associados a uma patologia humana ou animal, de gravidade variável, não representando riscos sérios para os profissionais do laboratório, para a comunidade, para os animais ou para o meio ambiente.

- Classe de risco 3 (alto risco individual e moderado risco para a comunidade): inclui os agentes que possuem um potencial de transmissão por via respiratória e que causam patologias, humanas ou animais, sérias e potencialmente letais. Podem ser tratados por medicamentos ou medidas terapêuticas, representando risco moderado para a comunidade e para o meio ambiente.

- Classe de risco $4>$ (alto risco individual e alto risco para a comunidade): agentes que podem ser transmitidos por via respiratória estão incluídos nesse caso. Não há qualquer medida profilática ou terapêutica eficaz contra infecções ocasionadas por esses agentes, até o momento. Causam doenças humanas e animais de alta gravidade, capazes de se disseminar na comunidade e no meio ambiente. Principalmente os vírus estão incluídos nessa classe.

\section{III.4.2 Biossegurança em biotérios}

Para se trabalhar com segurança é necessário que sejam observadas e respeitadas às regras e os procedimentos de trabalho formulados para excluir práticas perigosas e prevenir riscos desnecessários. A possibilidade de adquirir infecções em biotérios é grande, pois os animais de laboratório representam um 
risco para as pessoas que os manejam, podendo produzir aerossóis, morder, arranhar e mesmo que não estejam experimentalmente infectados, podem estar transportando agentes patogênicos, inclusive zoonóticos.

Grande parte dos odores provenientes das salas de animais, produzidos pela decomposição bacteriana dos excrementos, é agressiva para os seres humanos. No entanto, não se devem usar produtos que os mascarem, pois podem ser nocivos aos animais. Procedimentos de limpeza e ventilação adequada podem controlar esses odores.

O contaminante ambiental dos biotérios mais comum e mais sério é a amônia $\left(\mathrm{NH}_{3}\right)$, formado pela ação das bactérias (urease positivas) sobre os excrementos. Diversos fatores influenciam na concentração da amônia, como: ventilação, umidade relativa, desenho das gaiolas, número e sexo dos animais nas gaiolas, estado sanitário dos animais, alimentação etc.

É comum usar anestésicos voláteis, nas salas de cirurgia e de inoculação de animais de laboratório, embora não seja recomendado pelos padrões atuais, o éter ainda é muito utilizado. Além de produzir sintomas como cansaço, dor de cabeça, e irritabilidade, esse composto, pode apresentar peróxidos altamente explosivos, que já foram responsáveis por graves acidentes em laboratórios onde se realizam experiências com animais. Quando são usados outros anestésicos voláteis e que constituem riscos potenciais para a saúde, devem ser introduzidas medidas preventivas nas salas de cirurgia, minimizando a exposição a estes compostos (ANDRADE, 1996).

Em relação às medidas específicas de segurança para experimentação animal com agentes perigosos, deve ser dada atenção aos procedimentos sobre cuidados e alojamento de animais, armazenamento de agentes de risco e prevenção contra perigos causados por esses agentes, dosagem e administração de medicamentos, manuseio de tecidos e fluídos corporais, eliminação de excretas e carcaças e proteção pessoal. É exigido o emprego de equipamento de segurança específico bem como o seu manejo adequado, além de práticas seguras como o emprego de mini-isoladores e pressão negativa. Em resumo, 
para uma segurança eficiente, é necessário pessoal treinado e que cumpra rigorosamente a aplicação das normas de proteção contra riscos (CARDOSO, 1998).

Caso ocorram erros advindos da má utilização de materiais, técnicas incorretas, negligência ou falta de conhecimento, os profissionais estarão expostos a riscos freqüentes de infecção. Como cada laboratório pode ter uma combinação de riscos própria, deve ser feita uma avaliação para que as medidas de biossegurança necessárias sejam claramente identificadas. O responsável do laboratório e a comissão interna de biossegurança são responsáveis pela avaliação de riscos e pela aplicação adequada do nível de biossegurança recomendado (BRASIL-FUNASA, 2004).

Existem quatro níveis de biossegurança (NB), determinados para as atividades de doenças infecciosas utilizando pequenos animais de laboratório. As recomendações para os níveis de biossegurança para agentes específicos são feitas com base no risco potencial do agente, da função ou da atividade do laboratório. A experiência tem demonstrado a importância das precauções tomadas com as práticas, os procedimentos e as instalações dos níveis de biossegurança de 1 a 4 .

Tais ações são descritas para as manipulações de agentes etiológicos em montagem de laboratórios e dependências para animais, e que a adesão a essas normas contribui para um meio de trabalho mais seguro, saudável para os funcionários do laboratório, pesquisadores e a comunidade (BRASIL, 2004). Os critérios, recomendações e regras importantes para os níveis de biossegurança nos Laboratórios de Experimentação Animal estão esquematizados conforme detalhe (FIG.2) (MOLINARO et al., 2008; OMS, 2004; GRIST, 1996; BRASIL DIRETRIZES, 2004): 


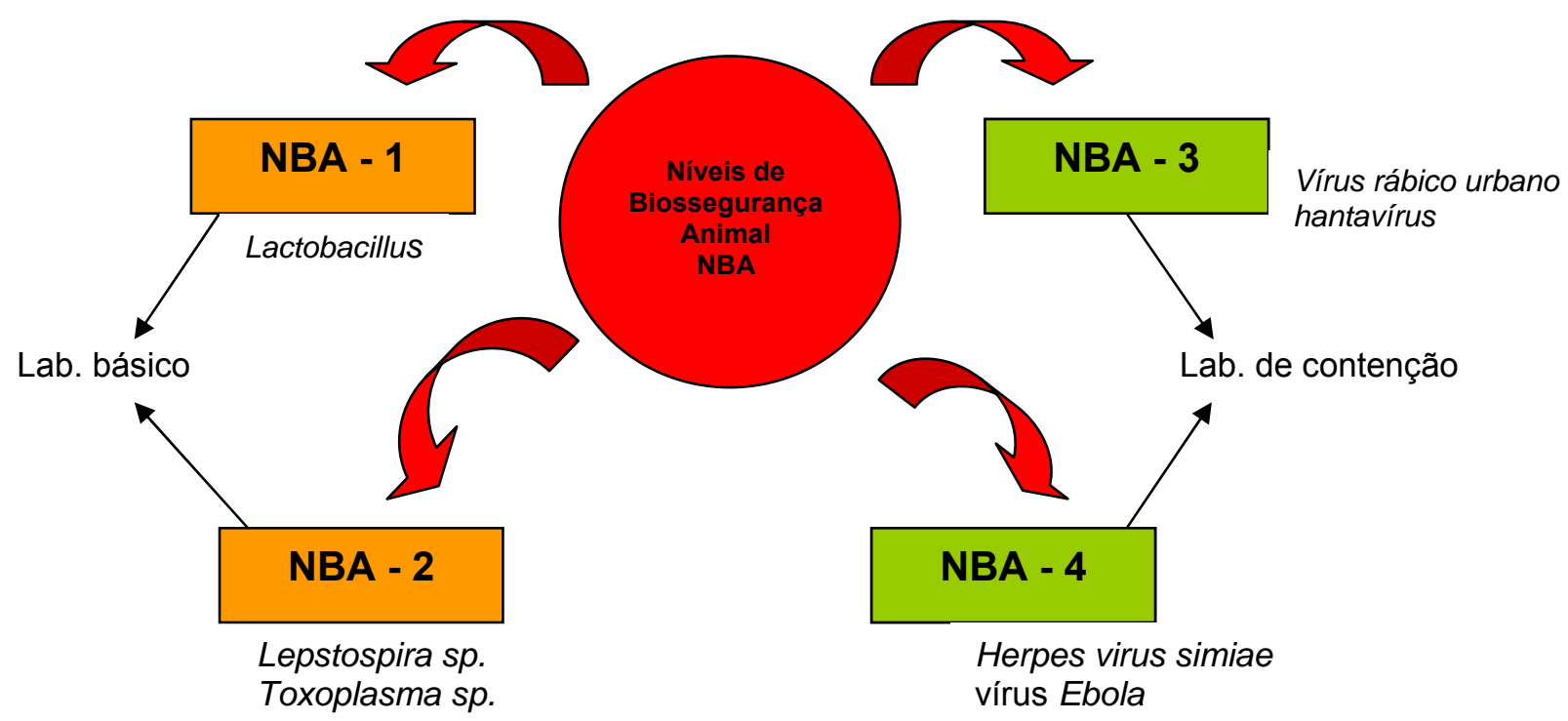

FIGURA 2 - Esquema dos quatro níveis de Biossegurança Animal (CARDOSO, 2008).

\section{Laboratório de Experimentação Animal - NBA 1}

Esse laboratório é considerado básico por manipular agentes biológicos da classe de risco 1. É recomendado para o trabalho que envolva agentes bem caracterizados, que não sejam conhecidos por provocarem doenças em humanos em geral e que apresentem um risco potencial mínimo para a equipe laboratorial e para o meio ambiente. É obrigatória a utilização de boas práticas laboratoriais, de alguns tipos de equipamentos de proteção individual e de requisitos mínimos de infra-estrutura.

Recomenda-se:

- Manter o laboratório limpo, organizado e isento de materiais que não são utilizados durante o trabalho.

- Desinfectar as superfícies de trabalho ao final do expediente ou após qualquer derramamento de material.

- Separar dos animais por espécie.

- Capacitar a equipe em relação às medidas de segurança e emergência. 
- Proibir ações como beber, comer, fumar, aplicar cosméticos, armazenar alimentos para consumo nas áreas de trabalho.

- Não usar calçados que deixem os artelhos à vista.

- Lavar as mãos após cada manuseio de material ou animal e antes de sair do laboratório.

- Afixar nas portas de acesso ao laboratório, o símbolo internacional de risco biológico, para não permitir a entrada de pessoas estranhas às atividades desenvolvidas pelo laboratório.

- Um programa de controle de roedores e insetos.

- Proibir a presença, dentro do laboratório, de animais que não sejam necessários ao trabalho.

- Usar luvas adequadas em todo o tipo de atividade que possa resultar em contato acidental direto com sangue, tecidos, fluidos ou animais infectados.

- Usar óculos de segurança e protetores de face (visores), contra os salpicos ou contra o impacto de objetos, por exemplo, no momento do preparo das caixas.

- Fechar as portas do laboratório durante o trabalho.

- Colocar nas caixas ou gaiolas de animais em experimentação, fichas de identificação do animal, tipo e duração do ensaio realizado, identificação do laboratório usuário responsável pelo ensaio e especificidades do ensaio quanto à segurança para o manejo dos animais.

- Descartar agulhas e vidrarias quebradas em recipientes com paredes rígidas, adequadamente identificadas.

- Usar jalecos, aventais e ou uniformes durante o trabalho na área dos laboratórios, não sendo permitido sua utilização fora das dependências do laboratório de experimentação animal como áreas de escritório, refeitório, biblioteca e salas de estar.

- Prever um kit de primeiros socorros na área de apoio ao laboratório.

- Um programa de vigilância médica adequado.

- Lavar gaiolas e caixas manualmente ou em máquina para lavagem mecânica. 
- Incinerar as carcaças dos animais. O lixo procedente das salas dos animais devem ser descontaminados, de preferência autoclavados, antes do descarte.

- Separar as áreas do edifício abertas ao público das dependências do laboratório de experimentação animal.

- Assegurar que as portas para passagem de equipamentos possuam dimensões com largura mínima de 1,10m.

- Evitar o acúmulo de poeira nas salas, minimizando áreas de superfície horizontal, como tubulações, luminárias de sobrepor, dutos de ar e outros.

- Instalar uma pia para lavagem das mãos, localizada próximo à porta.

- Selar janelas existentes ou instalar telas de proteção contra insetos.

- Cuidar para que as superfícies das paredes, pisos e tetos sejam lisos, não porosos, sem reentrâncias, impermeáveis à água e resistentes a produtos químicos e desinfetantes. O encontro das alvenarias e alvenarias com pisos deve ser com cantos arredondados. Os pisos não devem ser escorregadios.

- Nivelar pisos e tetos.

- Garantir espaço suficiente entre as bancadas, cabines e equipamentos de modo a permitir fácil acesso para a realização da limpeza.

- Cuidar para que a iluminação seja apropriada para as atividades, evitando reflexos e brilhos que prejudiquem a visão.

- Colocar mobília firme e resistente, com superfícies impermeáveis à água, lisas, sem emenda ou ranhura e resistente à ação de desinfetantes, ácidos, álcalis, solventes orgânicos e ao calor moderado.

- Facilitar a limpeza, colocando as estantes dos animais afastadas, no mínimo $20 \mathrm{~cm}$, das alvenarias.

- Planejar instalações destinadas para a guarda de roupas, objetos pessoais e refeitório, fora da área de trabalho. 
- Fluxo de ar para o interior do ambiente, no caso de ventilação mecânica. $\mathrm{O}$ ar exaurido deverá ser jogado para o lado de fora do prédio, sem recircular por outras salas.

- Usar água de boa qualidade e cuidar para que não falte.

- Prever local para o armazenamento de produtos químicos, fora da área do laboratório.

- Prever local específico, externo, coberto e ventilado para armazenamento de cilindros de gases, sendo mantidos na posição vertical e com dispositivos de segurança para evitar quedas ou tombamentos.

- Prever sistema de segurança contra incêndio e saída de emergência.

- Planejar, construir e manter as instalações de maneira a facilitar a limpeza e a manutenção.

\section{Laboratório de Experimentação Animal - NBA 2}

O nível de biossegurança 2 envolve práticas para o trabalho com agentes associados a doenças humanas. Este nível é indicado tanto para riscos advindos da ingestão quanto para exposições da membrana mucosa e cutânea. Deverão ser considerados todos os requisitos aplicáveis ao laboratório de experimentação animal NBA 1, acrescidos das normas gerais de procedimentos e práticas e instalações do laboratório.

Recomenda-se:

- Limitar o acesso às pessoas autorizadas. Quando o trabalho estiver sendo realizado, as pessoas deverão ser avisadas em relação aos eventuais perigos e riscos em potencial.

- Usar portas com fechamento automático e abertura para o interior das salas.

- Manter portas do laboratório fechadas durante o trabalho e no final das atividades as portas devem ser trancadas. 
- Preparar manual de segurança ou de procedimento onde constem os perigos eventuais ou já conhecidos, onde sejam especificadas as técnicas e rotinas capazes de reduzir ou eliminar tais riscos. A leitura e a obediência às normas e aos procedimentos padronizados devem ser exigidas.

- Proibir a entrada de crianças.

- Afixar aviso de risco biológico, na entrada da sala dos animais, sempre que houver agentes infecciosos presentes, com indicação do(s) agente(s) infeccioso(s), o nome e telefone da pessoa responsável pelo laboratório, além de indicar as recomendações especiais necessárias à manipulação dos mesmos.

- Utilizar luvas adequadas em qualquer tipo de atividade que possa resultar em contato acidental direto com sangue, tecidos fluídos ou animais infectados.

- Proibir a presença de alimentos de uso humano dentro das salas dos animais ou sala de procedimentos.

- Guardar as roupas utilizadas para proteção dentro do laboratório, em armário separado dos trajes pessoais.

- Conduzir procedimentos que apresentem um alto potencial de produção de aerossóis, sempre em cabines de segurança biológica e utilizando equipamentos de proteção individuais (EPl's), como por exemplo, máscaras contra gases, protetores faciais, dentre outros. Esses procedimentos incluem manuseio de fluídos ou tecidos, necropsia de animais infectados, líquidos de animais ou ovos infectados, inoculação intranasal de animais e manipulação de grandes volumes de material infeccioso.

- Remover com cuidado todo o material proveniente das camas de animais, de modo a diminuir a criação de aerossóis.

- Garantir à equipe do laboratório a imunização ou teste quanto à imunidade para os agentes manipulados ou potencialmente presentes no laboratório.

- Proibir a presença de pessoas susceptíveis às infecções, tais como as imunocomprometidas ou imunodeprimidas. 
- Providenciar um sistema de gerador, a fim de garantir a manutenção dos equipamentos indispensáveis, como, cabines de segurança biológica, freezer, dentre outros e garantir a ventilação das salas de manutenção de animais.

- Colocar portas com sistema de abertura sem a utilização das mãos, com visores e confeccionadas com material resistente ao fogo.

- Cuidar para que caso haja sistema de drenagem no piso, os ralos contenham água e/ou um desinfetante adequado, sejam sifonados e a tampa apresente sistema tipo abre e fecha.

- Guardar objetos pessoais em local específico.

- Colocar as cabines de segurança biológica longe das passagens de circulação e fora das correntes de ar provenientes de portas, janelas e sistemas de ventilação. Deve haver espaço de aproximadamente 0,30m atrás e em cada lado da CSB para facilitar o acesso e para a realização da limpeza e manutenção.

- Utilizar câmaras de segurança biológica (Classes 1e 2) ou caixas isolantes com fornecimento de ar e exaustores HEPA para trabalhos que impliquem eventualmente a produção de aerossóis.

- Transportar o material destinado a autoclaves ou incineração em recipientes fechados e de forma segura.

\section{Laboratório de Experimentação Animal - NBA 3}

Chamados de laboratório de contenção, NBA 3, estes laboratórios de experimentação animal, são locais que se destinam aos ensaios com animais, onde são manipulados agentes biológicos pertencentes à classe de risco 3 . Envolve as práticas adequadas para o trabalho com animais infectados por agentes nativos ou exóticos que apresentam potencial elevado de transmissão por aerossóis e risco de provocar doenças sérias ou fatais. Esse nível de contenção exige todos os requisitos aplicáveis ao laboratório de experimentação animal NBA 1 e NBA 2, acrescidos das normas gerais de procedimentos e práticas e instalações do laboratório. 
Recomenda-se:

- Limitar o acesso às salas dos animais ao menor número de pessoas possível. As pessoas autorizadas deverão ser avisadas em relação ao risco em potencial.

- Tomar banho na saída do laboratório

- Trabalhar usando a regra de duas pessoas, o que quer dizer que jamais uma pessoa deverá ficar sozinha dentro do laboratório.

- Afixar nas portas, o sinal de risco biológico, com identificação dos microorganismos manipulados e o nome do responsável pelo controle de acesso ao laboratório.

- Usar roupas de proteção, máscaras, luvas, gorros e sapatilhas. É obrigatório o uso de máscaras onde houver animais infectados.

- Autoclavar os EPl's usados antes de serem lavados ou descartados.

- Proibir o uso das roupas obrigatórias no laboratório em outro local e desinfetá-las antes de serem entregues à lavanderia.

- Fixar e vedar totalmente as janelas.

- Eliminar o ar de exaustão através de filtros especiais de elevado grau de eficácia (HEPA).

- Cuidar para que o acesso dos animais seja feito através de guichê ou câmara de transferência.

- Acessar a área através de uma ante-sala (air-lock) ou vestíbulo pressurizado.

- Colocar portas com sistema de intertravamento e revestimento metálico à prova de roedores.

- Proibir recirculação no sistema de ventilação.

- Colocar cabines de segurança biológica (Classe I ou II) com dutos para o exterior do prédio, com filtro HEPA para a exaustão do ar.

- Planejar a localização da área de escritório fora da área de contenção do laboratório.

- Colocar disjuntores e quadros de comando fora da área de contenção dos laboratórios para a devida manutenção quando necessário. 
- Colocar CSBs em todos os laboratórios.

- Prever um sistema de comunicação, ligando as áreas de contenção às áreas de suporte do laboratório e de apoio técnico da edificação.

- Colocar esquadrias de material de fácil manutenção e limpeza.

- Colocar visores vedados as salas e circulações e nas portas entre circulações.

- Instalar autoclave de porta dupla, na área de biocontenção, para a descontaminação de todo o material utilizado nesta área e saída de resíduos.

- Revestir o piso com materiais contínuos, sem juntas, tais como resinas monolíticas ou similares.

- Instalar lavatório para lavagem das mãos, com acionamento automático, ou acionado com o cotovelo ou pé, localizado próximo à porta de saída de cada laboratório.

- Usar câmara pressurizada ou outro sistema de barreira equivalente para a entrada de materiais de consumo e amostras biológicas (humanas e animais).

- Colocar um sistema de ar independente, com ventilação unidirecional, garantindo que o fluxo de ar seja sempre direcionado das áreas de menor risco potencial para as áreas de maior risco de contaminação.

- Proibir a circulação do ar de exaustão para qualquer outra área da edificação, devendo ser filtrado por meio de filtro HEPA, antes de ser eliminado para o exterior do laboratório, longe de áreas ocupadas e de entrada de ar.

- Manter os sifões em retenção cheios de um desinfetante ativo.

- Fechar hermeticamente o perímetro do laboratório, de modo a permitir descontaminação química ou gasosa.

\section{Laboratório de Experimentação Animal - NBA 4}

O nível de biossegurança animal 4 , chamados de laboratório de contenção máxima, NBA 4, envolve as práticas adequadas para o trabalho com agentes 
perigosos ou exóticos que exponha o indivíduo a um alto risco de infecções que podem ser fatais, além de apresentarem um potencial elevado de transmissão por aerossóis ou de agentes relacionados com um risco de transmissão desconhecido. Esse nível de contenção exige todos os requisitos aplicáveis ao laboratório de experimentação animal NBA 1, NBA 2, NBA3, acrescidos das normas gerais de procedimentos e práticas e instalações do laboratório.

Recomenda-se:

- Equipar a área de entrada com cartão magnético, leitor de íris ou digitais ou outro sistema de segurança com controle automatizado. O acesso deverá ser rigorosamente controlado.

- Usar ante-sala para a entrada e saída de pessoas

- Exigir que as pessoas troquem todas as roupas ao entrarem no laboratório. Ao saírem às pessoas devem tomar um banho.

- Controlar o sistema de ventilação/exaustão para garantir pressão negativa.

- Direcionar o fluxo de ar para o interior do laboratório.

- Colocar um sistema de exaustão do ar provido de dois filtros HEPA.

- Acessar os materiais através de antecâmara de passagem.

- Esterilizar e incinerar os resíduos que forem produzidos nessa área.

- Cuidar para que a autoclave para esterilização de lixo e materiais seja do tipo de passagem, ou seja, com duas portas.

- Prever um sistema de comunicação, com circuito interno de imagem e/ou outro mecanismo de comunicação de emergência entre as áreas de contenção e as áreas de suporte do laboratório e de apoio técnico da edificação.

- Colocar um sistema eficiente de contenção primária, constando de equipamentos como câmaras de segurança biológica da classe III e macacões ventilados com pressão positiva. Neste último caso exigese um chuveiro especial para desinfecção química das pessoas que deixam o vestiário. 
A Comissão Técnica Nacional de Biossegurança (CTNBio), no uso de suas atribuições legais e regulamentares, através da Resolução Normativa $\mathbf{N}^{\circ} \mathbf{2}$, de 27 de novembro de 2006 (Dispõe sobre a classificação de riscos de Organismos Geneticamente Modificados (OGM) e os níveis de biossegurança a serem aplicados nas atividades e projetos com OGM e seus derivados em contenção) revoga as Instruções Normativas No 06 de 28 de fevereiro de 1997, No 7 de 6 de junho de 1997 (Normas para o trabalho em contenção com organismos geneticamente modificados - OGMs), No 12 de 27 de maio de 1998 (Normas para trabalho em contenção com animais geneticamente modificados) e $\mathbf{N}^{0} 15$ de 8 de julho de 1998. No capítulo VIII, a Resolução Normativa $N^{\circ} 2$, define os aspectos de instalações, equipamentos, bem como os procedimentos e práticas a atender os trabalhos em contenção (BRASIL, 2006).

Capítulo VIII

Das Instalações Físicas e Procedimentos em Contenção para Atividades e Projetos com Animais Geneticamente Modificados.

Art. 22 As instalações de contenção para atividades e projetos com animais geneticamente modificados incluem biotério, insetário, tanque de aqüicultura, curral, aviário, infectório, entre outros.

Art. 23 As atividades e projetos em contenção envolvendo animais geneticamente modificados da classe de risco 1 deverão atender às normas de biossegurança exigidas para o NB-1, acrescidas de:

I - as instalações para manutenção e manipulação dos animais geneticamente modificados devem estar fisicamente separadas do resto do laboratório e ter acesso controlado;

II - a entrada das instalações deve ser mantida trancada, sendo o acesso restrito às pessoas credenciadas pela CIBio da Instituição;

III - a construção das instalações deverá levar em conta o tipo de animal geneticamente modificado a á levar em conta o tipo de animal geneticamente modificado a ser mantido e manipulado, mas sempre tomando-se os cuidados necessários para impedir o escape; 
IV - todas as áreas que permitam ventilação (inclusive entrada e saída de ar condicionado) deverão conter barreiras físicas para impedir a passagem de insetos e outros animais;

V - ralos ou outros dispositivos similares, se existentes, deverão ter barreiras para evitar a possibilidade de escape ou entrada de material contaminado;

VI - animais de diferentes espécies e não envolvidos no mesmo experimento deverão estar alojados em áreas físicas separadas;

VII - recomenda-se a instalação de cortinas de ar com fluxo de cima para baixo nas portas de acesso;

VIII - tanques de aqüicultura devem ter a renovação de água em sistema separado, sendo toda a água de descarte passada por tanque de esgotamento com desinfecção, antes de ser lançada na rede pluvial;

IX - currais para inspeção e colheita de amostras deverão conter infraestrutura adequada ao manejo dos animais, assim como piquetes com cerca dupla, para evitar o trânsito entre áreas, pedilúvio e, quando possível, sistema de drenagem passando por tanque de desinfecção;

$X$ - recomenda-se que a entrada de serragem, ração ou qualquer outro alimento ou material a ser utilizado com os animais ocorra após autoclavagem ou irradiação;

$\mathrm{XI}$ - todo material contaminado deverá ser apropriadamente acondicionado para desinfecção ou inativação, que poderá ocorrer fora das instalações;

XII - devem ser estabelecidas normas de procedimentos amplamente divulgadas às pessoas com acesso autorizado;

XIII - cópias das normas de procedimentos, inclusive daqueles referentes a situações de emergência, devem ser mantidas no interior das instalações;

XIV - no caso de manutenção de um banco de embriões geneticamente modificados criopreservados, este deve localizar-se nas instalações credenciadas pela CTNBio.

Art. 24 As atividades e projetos em contenção envolvendo animais geneticamente modificados da classe de risco 2 deverão atender às normas de biossegurança exigidas para o NB-2 e as especificações do artigo 23 desta Resolução Normativa, acrescidas de: 
I - é necessário que haja uma ante-sala entre a área de livre circulação e a área onde os animais estão alojados;

II - a ante-sala deve estar separada por sistema de dupla porta com intertravamento;

III - todas as entradas e saídas de ventilação devem possuir barreiras físicas que bloqueiem a passagem de insetos e outros animais entre as salas e a área externa;

IV - as janelas devem ter vidros fixos e hermeticamente fechados e, quando necessário, serem duplas;

$\mathrm{V}$ - as instalações devem ter luzes de emergência e serem ligadas a geradores, se possível;

VI - é necessária a troca de vestimenta antes da passagem da ante-sala para a sala de animais. Se possível, deve ser utilizada vestimenta descartável no interior da sala de animais;

VII - as vestimentas devem, após rigorosa inspeção para verificar a presença de insetos, ser acondicionadas em recipiente próprio fechado e autoclavado;

VIII - serragem, ração ou qualquer outro alimento ou material a ser utilizado com os animais devem ser submetido à autoclavagem ou irradiação;

IX - a saída do material deve ser efetuada através de câmaras de passagem de dupla porta para esterilização ou inativação;

X - em biotérios, a água a ser ingerida pelos animais deve ser filtrada, acidificada ou autoclavada.

XI - em biotérios, o fluxo de ar deve sofrer cerca de 20 renovações por hora;

XII - recomenda-se que haja controle sanitário, parasitológico, microbiológico, de micoplasmas e virológico dos animais;

XIII - controle genético dos animais deve ser realizado, se possível, a cada nova geração;

XIV - infectórios com animais geneticamente modificados devem localizarse em áreas especialmente isoladas e devidamente credenciadas pela CTNBio.

Art. 25 As atividades e projetos em contenção envolvendo animais geneticamente modificados da classe de risco 3 deverão atender às normas de 
biossegurança exigidas para o NB-3 e as especificações dos artigos 23 e 24 desta Resolução Normativa, acrescidas de:

I - as instalações deverão conter, no mínimo, as seguintes áreas distintas; Ante-sala, Sala de Materiais, Sala para Animais e Sala de Experimentação;

II - a ante-sala deverá possuir três divisões. Na primeira divisão, deverá haver armários individuais para o usuário guardar as roupas. Na divisão central, deverá haver chuveiros acionados por sistema independente do uso das mãos. $\mathrm{Na}$ terceira divisão, deverá haver armários fechados para guardar roupas esterilizadas a serem utilizadas pelos usuários e sacos para acondicionar a roupa já utilizada nas instalações, que deverá ser autoclavada antes de ser descartada.

III - o ar insuflado deve ser esterilizado. A saída de ar também deve conter filtros esterilizantes para purificação do ar antes de ser lançado para o meio externo;

IV - as salas dos animais e de experimentação devem, necessariamente, conter pressão de ar negativa em relação às demais salas;

V - as instalações devem possuir sistema de controle automático para detectar alterações na pressão atmosférica e capaz de acionar alarme;

$\mathrm{VI}$ - os animais devem estar alojados, quando pertinente, em sistema de microisoladores ou em sistemas equivalentes;

VII - quando houver torneiras, estas devem permitir acionamento sem o uso das mãos;

VIII - todo material a ser descartado deverá ser previamente descontaminado dentro das instalações. Isto deverá ocorrer pelo uso de autoclave de dupla porta;

IX - os animais mortos e os dejetos deverão ser incinerados.

Art. 26 Normas específicas para atividades e projetos com animais geneticamente modificados da classe de risco 4 serão editadas pela CTNBio quando necessário.

Outra questão importante a ser abordada com relação à segurança, são os cuidados que se devem ter no manejo de resíduos do biotério. Os resíduos em instituições de saúde, onde incluem, os de laboratórios favorecem um ambiente 
para o aparecimento de vetores como insetos e roedores, podendo causar perigo a saúde humana e ao meio ambiente quando forem tratados, armazenados e transportados indevidamente (CAMPANER, SOUZA, 2002).

Os resíduos de serviços de saúde são regulamentados pela Associação Brasileira de Normas Técnicas (ABNT), de acordo com a NBR - 12807/1993 (Resíduos de serviços de saúde - Terminologia), NBR - 12808/1993 (Resíduos de serviços de saúde - Classificação), NBR - 12809/1993 (Manuseio de resíduos de serviços de saúde - Procedimento), NBR 12810/1993 (Coleta de resíduos de serviços de saúde - Procedimento) e NBR 14652/2001 (Coletor - transportador rodoviário de resíduos sólidos de serviços de saúde) (ABNT, 1993).

De acordo com a Resolução da Diretoria Colegiada, da Agência Nacional de Vigilância Sanitária/ANVISA - RDC $N^{\circ} 306$, de 7 de dezembro de 2004, que dispõe sobre o regulamento técnico para o gerenciamento de resíduos de serviços de saúde (RSS), sendo constituído por um conjunto de procedimentos de gestão, tem como objetivo diminuir a produção de resíduos e proporcionar aos resíduos gerados, um direcionamento seguro, de maneira eficaz, visando proteger os trabalhadores, preservar a saúde pública, os recursos naturais e o meio ambiente. Essa resolução revoga a Resolução ANVISA - RDC N $\mathbf{N}^{\circ}$ 33, de 25 de fevereiro de 2003.

Deve ser adotado por todo laboratório gerador de RSS, um Plano de Gerenciamento de Resíduos de Serviços de Saúde - PGRSS, baseado nas características dos resíduos gerados. O PGRSS a ser elaborado deve ser compatível com as normas federais, estaduais, municipais e também estar de acordo com os procedimentos institucionais de Biossegurança, com relação à coleta, transporte e disposição final dos resíduos gerados (FIOCRUZRESÍDUOS).

É necessário também conhecer os produtos e materiais manejados no laboratório e os riscos que podem representar danos à saúde das pessoas e ao meio ambiente. Ferreira (1996) e Cardoso (1998) estabelecem alguns cuidados 
necessários à segurança com relação à manipulação de resíduos nos Biotérios, como (BARBOZA, 2001):

- Esterilizar em autoclaves ou incinerar, antes do descarte, animais e maravalhas;

- Posicionar e indicar adequadamente os avisos claros e visíveis nos recipientes para descarte de resíduos;

- Utilizar material descartável de forma restrita e racional;

- Escolher e utilizar adequadamente os produtos de laboratório;

- Reduzir a criação de resíduos no laboratório;

- Utilizar métodos eficientes de reciclagem dos resíduos, visando à segurança do meio ambiente;

- Esterilizar os resíduos sólidos durante o trabalho, utilizando os métodos de autoclavação ou esterilização química;

- Observar que antes de serem lançados na rede de esgoto, os resíduos líquidos podem ser autoclavados ou sofrerem desinfecção química;

- Prever a separação de materiais para reciclagem antes do descarte no recipiente de acondicionamento geral;

- Acondicionar os resíduos de maneira segura e eficaz. Durante o transporte, não poderá haver ruptura do acondicionamento, para evitar o risco de disseminação;

- Manipular com atenção os resíduos químicos, no que diz respeito a situações provocadas por reações quando da mistura com outros produtos;

- Estocar resíduos com radioatividade de meia vida curta conforme padrões estabelecidos pela Norma CNEN-NE-6.05, até o decaimento da radioatividade para níveis em que não sejam mais considerados radioativos;

- Manter resíduos comuns e os perigosos separadamente, de forma eficiente e segura. Caso esta separação não tenha sido realizada, considera-se todo o resíduo como perigoso. 
A aplicação de medidas de controle rígido do destino final dos resíduos gerados é hoje uma questão ética, pois coloca em risco a saúde dos profissionais, dos técnicos e da população em geral ((FERREIRA, 1996) apud BARBOZA, 2001).

\section{III.5 Aspectos Relevantes do Ambiente Físico}

Os animais devem ser alojados em instalações construídas ou destinadas para esse fim e não simplesmente ser acomodados em laboratórios. As condições de alojamento e das instalações dos animais são fundamentais ao bem-estar dos animais, à qualidade das pesquisas, nos procedimentos em que se utilizam animais e, também, à saúde e segurança das pessoas neles envolvidas. É importante que os animais cresçam, se desenvolvam e se reproduzam em perfeito estado de saúde e bem-estar, minimizando as variações que possam afetar os resultados das pesquisas. Vários fatores devem ser examinados na elaboração de um planejamento sobre ambiente, condições de alojamento e manejo de animais, tais como (NRC, 2003).

- Espécie, linhagem e raça do animal;

- Projeto e condições de construção do alojamento;

- Presença de materiais perigosos ou causadores de doenças;

- Permanência do período de contenção do animal;

- Capacidade dos animais de poder formar grupos com indivíduos da mesma espécie;

- Objetivos do projeto e a definição experimental (produção, reprodução pesquisa, testes e ensino);

- Intensidade da manipulação animal e grau de invasão dos procedimentos realizados. 
Os animais devem ser alojados convenientemente com a intenção de maximizar os comportamentos específicos da espécie e minimizar os comportamentos individuais de estresse. Os locais onde se mantêm animais devem ser próprios à espécie, ao seu histórico, aos objetivos de seu uso e com as condições ambientais mantidas em níveis sem variações, pois o padrão sanitário dos animais é assegurado com a manutenção de condições ambientais estáveis (COUTO, 2006; NRC, 2003).

Os biotérios devem ser projetados visando atender às recomendações para a criação ou manutenção de animais e para minimizar os efeitos do meio ambiente nas variáveis do animal, com instalações planejadas, bem construídas e com funcionamento adequado e eficiente, garantindo a qualidade das pesquisas, o bem-estar do animal e a segurança das pessoas (WHO, 2001; CPCSEA, 2003; RICHMOND, 2000; IVIS, 2003; NRC, 2003 apud MAJEROWICZ, 2005).

Os principais fatores ambientais limitantes para criação e manutenção de animais de laboratório são a temperatura, a umidade relativa, a ventilação, a iluminação e o ruído. Em termos de resposta biológica, todo experimento animal é a composição de efeitos genéticos e ambientais.

Muitos fatores físicos, químicos e microbiológicos do ambiente, acrescidos aos fatores genéticos, podem de alguma forma, influenciar a resposta do animal ao estímulo experimental. Meio ambiente e espaços mal planejados podem propiciar situações dramáticas como a super aglomeração que leva à asfixia ou ao canibalismo.

O ambiente artificial altera, por vezes, aspectos comportamentais essenciais. Price (1976) observou tal transformação em espécies que praticam a territorialidade, mas que em cativeiro, passam a estabelecer hierarquias sociais, desde que os indivíduos menos fortes não têm como evitar os indivíduos dominantes. 


\section{III.5.1 Micro e macro ambiente}

O ambiente onde o animal se encontra é separado em macro e microambiente, sendo a gaiola o divisor entre os dois. Tudo o que está do lado externo da gaiola constitui o macro ambiente e tudo o que está em seu interior constitui o microambiente (SANTOS, 2006). Ambientes mais seguros e estáveis, livres de doenças, econômicos e cientificamente melhor aceitos, são determinantes como padrões mínimos sobre macro e microambiente, pois proporcionam o bem-estar animal e segurança para os técnicos (MEZADRI et al., 2004).

O microambiente é o espaço físico imediatamente próximo ao animal, quer dizer, a gaiola ou o recinto primário, com temperatura própria, umidade relativa, composição de gases e partículas do ar. Os recintos primários aceitáveis possibilitam à realização das necessidades fisiológicas e comportamentais normais dos animais, a interação social, a ventilação adequada, o acesso à comida e à água, a simples manutenção e limpeza dos bebedouros e comedouros, facilitando a higiene e proporcionando conforto físico aos animais.

A gaiola com fundo sólido e cama é o tipo de alojamento recomendado para roedores. O animal deve ter espaço suficiente para realizar movimentos corporais normais, ter acesso a comida e água, e espaço suficiente para exercícios com cama limpa (NRC, 2003). Atualmente, as gaiolas são confeccionadas em diversos tipos de plásticos, com dimensões padronizadas.

A "cama" que é utilizada no fundo das gaiolas, ou em bandejas, deve ter alta capacidade de absorção de umidade, sem desidratar ou machucar os recémnatos, sem poeira, estar livre de agentes químicos ou patogênicos, não ser abrasiva, serem de baixo custo e de fácil obtenção. O material usado para as camas dos animais é um fator que pode influenciar os dados experimentais e o bem-estar animal. Com relação à quantidade de animais por caixa, recomendamse os seguintes parâmetros, conforme resumo (TAB. 2). 
TABELA 2 - Espaço recomendado para roedores de laboratório comumente usados e alojados em grupos (NRC, 2003).

\begin{tabular}{|c|c|c|c|}
\hline Animais & Peso (massa), $g$ & Área do piso/animal, $\mathrm{pol}^{2}$ & Altura, pol \\
\hline \multirow[t]{4}{*}{ Camundongos } & $<10$ & 6 & 5 \\
\hline & Até 15 & 8 & 5 \\
\hline & Até 25 & 12 & 5 \\
\hline & $>25$ & $\geq 15$ & 5 \\
\hline \multirow[t]{6}{*}{ Ratos } & $<100$ & 17 & 7 \\
\hline & Até 200 & 23 & 7 \\
\hline & Até 300 & 29 & 7 \\
\hline & Até 400 & 40 & 7 \\
\hline & Até 500 & 60 & 7 \\
\hline & $>500$ & $\geq 70$ & 7 \\
\hline \multirow[t]{4}{*}{ Hamsters } & $<60$ & 10 & 6 \\
\hline & Até 80 & 13 & 6 \\
\hline & Até 100 & 16 & 6 \\
\hline & $>100$ & $\geq 19$ & 6 \\
\hline \multirow[t]{2}{*}{ Cobaias } & $\leq 350$ & 60 & 7 \\
\hline & $>350$ & $\geq 101$ & 7 \\
\hline
\end{tabular}

A maravalha de pínus (raspas de madeira) é o material mais usado para a cama, devendo ser autoclavado ou irradiado antes de ser usado, pois constitui uma importante fonte de contaminação para os animais (SANTOS, 2006). Para evitar contaminação e garantir a qualidade, as camas devem ser colocadas em estrados, estantes ou carrinhos, sendo transportadas e armazenadas, sem manter contato com o chão (NRC, 2003).

Outro fator importante para os animais de laboratório é o odor, uma vez que o reconhecimento e a identificação dos indivíduos se fazem pelo cheiro inato de cada espécie, pois, por meio dos feromônios, machos e fêmeas se encontram para a reprodução e demarcam os seus territórios (SANTOS, 2006).

Nas instalações onde os animais são alojados, não devem ser utilizados agentes com a finalidade de inibir os odores produzidos pelos animais, pois expõem os animais a compostos voláteis que podem alterar processos fisiológicos e metabólicos (NRC, 2003). Devemos eliminar os odores que causam irritação, como a amônia, e os alheios à espécie, através de boa ventilação, renovação do ar, adoção de boas práticas de higiene e pela sanitização dos materiais e equipamentos (SANTOS, 2006). 
Os responsáveis pelas colônias de animais devem ser criteriosos na aquisição, no transporte, no armazenamento e na manipulação do alimento, evitando a introdução de doenças, parasitas, vetores potenciais de doenças (por exemplo, insetos e outras pragas) e contaminantes químicos nesses locais (NRC, 2003). A ração oferecida ao animal deve ser autoclavada ou irradiada para evitar contaminações.

Devem ser armazenadas distantes do chão, em estrados, prateleiras ou carrinhos e os locais, onde são preparadas as dietas e seus ingredientes, devem ser mantidos limpos e fechados, para evitar a entrada de pragas. Os animais devem ter acesso normal à água potável, devendo ser microbiologicamente pura (esterilizada), uma vez que se constitui importante fonte de contaminação. A troca de água deve ser freqüente e os bicos por onde o animal bebe devem ser em aço inoxidável e autoclavados antes do contato com os animais (SANTOS, 2006). A escolha dos métodos de tratamento de água deve ser cuidadosa, pois muitas formas de tratamento podem causar alterações fisiológicas, mudanças na microflora ou efeitos nos resultados experimentais (NRC, 2003).

O macro ambiente é o ambiente físico secundário, por exemplo, sala para a colônia de animais, áreas de apoio, áreas de higienização e esterilização, salas de estoque de materiais limpos e insumos, corredores de acesso, etc. $\mathrm{Na}$ definição do projeto de arquitetura de um biotério, é fundamental que as instalações destinadas aos animais sejam separadas fisicamente dos laboratórios de controle ou experimentação e áreas administrativas, e também possuam estrutura adequada que impeça o acesso de agentes infecciosos e vetores, como insetos e roedores silvestres, definindo ao mínimo possível a circulação de animais e pessoal (SANTOS, 2006).

\section{III.5.2 Temperatura e umidade}

A maioria das espécies de animais de laboratório é homeoterma, quer dizer, regula a temperatura corpórea dentro de uma estreita faixa variando sua taxa metabólica (mecanismos de compensação do organismo para se adaptar às condições do ambiente) (VALERO et al., 1990). 
Para mantermos a higidez animal, é necessário que nos preocupemos com a temperatura e a umidade relativa do ambiente. A temperatura é mantida resfriando-se ou aquecendo-se o ar que entra nas salas de criação, por meio de um elaborado sistema de condicionamento de ar. Para pequenos roedores a temperatura de conforto é de $21^{\circ} \mathrm{C}$ a $24^{\circ} \mathrm{C}$. Cobaias e coelhos se adaptam melhor a temperaturas de $18^{\circ} \mathrm{C}$ A $20^{\circ} \mathrm{C}$. A gaiola serve de divisor dos macro e microambientes, sabendo-se que no seu interior a temperatura pode aumentar de $3^{\circ} \mathrm{C}$ a $5^{\circ} \mathrm{C}$, bem como a umidade é sempre mais elevada. Alterações bruscas de temperatura podem provocar estresse no animal, ocasionando queda de resistência e maior sensibilidade às infecções. Queda na reprodução e até sua parada total, podem ser provocadas pela temperatura alta e afecções respiratórias podem ser provocadas por temperaturas baixas.

Outro fator importante para o bem-estar animal é a umidade relativa. Devido à liberação contínua de vapor d'água, através da respiração e pela evaporação da urina, a umidade dentro das salas tende sempre a aumentar, sendo necessário um sistema que retire com eficiência o excesso de água do ambiente.

Esses procedimentos devem ser realizados durante a troca de ar da sala, com controle, para que a retirada de vapor não seja excessiva, para não deixar o ambiente muito seco, o que provoca problemas respiratórios com ressecamento de mucosas, pele e surgimento de feridas nos animais. Por outro lado, a umidade muito alta, favorece problemas respiratórios. A umidade considerada ideal para roedores e lagomorfos é de $45 \%$ a $55 \%$ (TAB. 3) (SANTOS, 2006).

TABELA 3 - Condições ambientais (NRC, 2003).

Animal

Umidade (\%)

Camundongo, rato, hamster, coelho

$55 \pm 10$ 
A temperatura e umidade relativa estão associadas aos níveis de metabolismo e comportamento animal. Para cada espécie animal existe uma faixa requerida de temperatura e umidade ambiental, na qual a temperatura corporal pode ser mantida constante através de mecanismos termorreguladores (TAB. 4). Para estabelecer as condições ambientais de temperatura e umidade deverá ser considerada a transferência de calor por irradiação do animal para o ambiente, a perda de calor livre ou forçado devido ao movimento do ar e a perda de calor por condução desde o corpo do animal aos materiais que entram em contato com ele. Além disto, para ajuste das condições térmicas, deverão ser considerados ainda aqueles fatores que foram impostos aos animais para fins de sua adaptação, tais como tamanho e material da gaiola, a presença ou ausência de material de cama, densidade populacional e outros. Há de se ressaltar, que os animais podem se adaptar a extremos por meio de mecanismos comportamentais, fisiológicos e morfológicos, mas tal adaptação requer tempo e pode alterar os resultados do protocolo, ou, de outro modo, afetar o desempenho dos animais (NRC, 2003).

TABELA 4 - Temperaturas recomendadas para animais usados comumente em laboratório (NRC, 2003).

\begin{tabular}{lcc}
\hline \multirow{2}{*}{ Animal } & \multicolumn{2}{c}{ Temperatura } \\
& ${ }^{\circ} \mathrm{C}$ & ${ }^{\circ} \mathrm{F}$ \\
\hline Camundongo, rato, hamster, gerbo, cobaia & $18-26$ & $64-79$ \\
Coelho & $16-22$ & $61-72$ \\
Gato, cão, primata não-humano & $18-29$ & $64-84$ \\
Animais de fazenda e aves & $16-27$ & $61-81$ \\
\hline
\end{tabular}

As variações diárias de temperatura, no caso de animais alojados em espaços confinados, devem ser mínimas de modo a evitar, pelo menos, grandes e contínuas demandas dos processos metabólicos e comportamentais empregados para compensar as mudanças de temperatura do ambiente. O controle da umidade relativa também é necessário, mas não de modo tão rigoroso e preciso quanto à temperatura. A umidade relativa é, então, a maior responsável pela 
rapidez de evaporação e dispersão de gotículas que, em suspensão, influenciam na sobrevivência de microorganismos (MAJEROWICZ, 2005).

\section{III.5.3 Ventilação}

O sistema de ventilação adequadamente instalado e controlado serve para evitar a propagação de odores e agentes patógenos transportados pelo ar. A atmosfera na qual os animais vivem deve oferecer condições que permitam a atividade do animal sem obstáculo. A função principal do sistema de ventilação é fornecer oxigênio, diluir gases e partículas contaminantes, remover alterações térmicas causadas pela respiração, iluminação e equipamentos, além de remover os produtos do metabolismo em geral, como por exemplo: odores desagradáveis e a poeira desprendida da maravalha, podendo prejudicar a saúde dos animais (VALERO et al., 1990).

Para controlar a temperatura, a umidade e diluir os possíveis poluentes químicos (resíduos de desinfetantes usados na higienização das salas), é fundamental um sistema de ventilação que produza trocas regulares do ar na sala de animais (SANTOS, 2006). Fornecimento de suprimento de oxigênio adequado; remoção das massas de ar quente, produzidas pela respiração animal, por luzes e equipamentos; diluição de contaminantes gasosos; ajuste do conteúdo de umidade do ar da sala; e, quando necessário, criação de diferenciais de pressão estática entre espaços adjacentes, são considerados objetivos da ventilação. Por muitos anos vem se adotando a prática de 10 a 15 trocas de ar fresco por hora para recintos secundários (CARDOSO, 1998). A circulação do ar necessita de um sistema que seja capaz de retirar do ar partículas de patógenos. O objetivo da filtração é reter partículas de poeira e microorganismos, responsáveis pela contaminação e poluição do ambiente. A filtração considerada ótima está em 99,97\% de retenção de partículas acima de 0,5mm (SANTOS, 2006).

O alojamento em gaiolas com ventilação forçada, que utiliza ar filtrado da sala, e outros tipos de recintos primários especiais, com suprimentos de ar independentes (isto é, ar não extraído da sala), podem efetivamente suprir as necessidades de ventilação dos animais, sem a necessidade de ventilar os 
recintos secundários. Entretanto, um recinto secundário deve ser suficientemente ventilado para controlar o volume de calor liberado dos recintos primários (NRC, 2003).

O fluxo de ar de áreas sujas para áreas limpas deve ser banido e as pressões de ar deverão ser sempre maiores nas áreas limpas ou estéreis, nas quais é requerida menor contaminação ou maior assepsia. Nas salas de experimentação animal, as pressões de ar devem ser sempre menores que nos corredores de acesso, para que seja evitada a contaminação ambiental por microorganismos patogênicos. Os gradientes de pressão, além do diferencial de pressão, deverão também ser assegurados. Por exemplo: os gradientes de pressões em áreas estéreis ou limpas para as áreas sujas devem ser: depósito de suprimentos esterilizados e corredor limpo: tripla positiva; salas de animais devem possuir pressão dupla positiva; corredor sujo pressão positiva simples e o exterior, pressão normal (TORU URANO et al., 1995).

\section{III.5.4 Iluminação}

A intensidade, a claridade e o fotoperíodo são características que podem influir sobre os animais de laboratório. A iluminação deve promover uma boa visibilidade e uma luz uniforme, sem reflexos.

O ciclo reprodutivo de muitas espécies é controlado pela duração do dia (ritmo circadiano), uma vez que o estímulo da luz produz variação nos níveis hormonais. Variações sazonais são minimizadas com a manutenção constante, geralmente de 12 horas de luz e 12 horas de escuridão. Períodos prolongados de iluminação ou de escuridão interferem no ciclo reprodutivo dos animais (VALERO et al., 1990).

Um dos fatores que mais influenciam o ritmo biológico do animal de laboratório é sem dúvida o fotoperíodo (ciclo de luz/escuridão), atuando no seu comportamento e na reprodução. Sendo a maioria dos roedores animais noturnos, a luz fria causa menos irritação do que a luz incandescente e a iluminação natural é desaconselhável, pois não pode ser controlada. Períodos de 
luz de 12-14 horas/24 horas parecem ser os mais adequados à reprodução dos animais e a sua manutenção (SANTOS, 2006).

O fotoperíodo é um regulador crítico do comportamento reprodutivo em muitas espécies de animais, podendo alterar o aumento de peso corporal e a ingestão de alimentos. Recomenda-se minimizar ou evitar a exposição acidental à luz durante o período escuro do ciclo (NRC, 2003). Na definição das condições ambientais de luz, deverão ser considerados a duração do fotoperíodo (horas/luz $X$ horas/escuro), a intensidade expressa em Lux (lumens/m2) e o comprimento de onda, expressa em Angstrom. A luz visível estimula fotorreceptores e é responsável pela fotoperiodicidade, que regula os ritmos circadianos, ciclos reprodutivos, atividade locomotora, consumo de água e alimentos, temperatura corpórea, toxicidade e efetividade de drogas, níveis séricos de lipídeos e de outros elementos. O fotoperíodo deverá ser controlado. A luz é um fator sincronizador que origina o sistema circadiano, que é uma adaptação filogenética quase sincrônica com a rotação da Terra. A duração do fotoperíodo é um assunto ainda em discussão. Temos ainda alguns fatores interferentes, tais como a localização das caixas nas estantes e o material usado na confecção das caixas, dentre outros. É um engano achar que a iluminação obtida através das janelas ou vidraças é natural. A luz obtida desta forma apresenta um espectro mais vermelho, para o qual os animais de laboratórios são insensíveis, e menos violeta, que, além de elevar a carga térmica do recinto, aumenta o custo dos equipamentos de climatização (WEIHE, 1976).

Já a intensidade de luz é outro fator ligado à iluminação. Podemos verificar que, diferentemente do homem, a maior parte das espécies de laboratório não pode distinguir cores, mas em compensação, eles estão adaptados para ver melhor que o homem, com pouca iluminação. É recomendado que a intensidade de luz dentro da caixa, não ultrapasse 60 lux (medida da intensidade de luz, em unidades). Na sala de animais de laboratório, os níveis de intensidade variam muito. Pode-se utilizar a seguinte referência: 350 a 400 lux um metro acima do chão, diretamente debaixo da fonte de luz (VALERO et al., 1990). 
A luz deve abranger toda a área de manutenção dos animais, proporcionar iluminação suficiente para o seu bem-estar, permitindo boas práticas de cuidado; fornecer inspeção adequada dos animais, até mesmo, com as gaiolas colocadas nas prateleiras mais baixas e oferecer condições seguras de trabalho para as pessoas (NRC, 2003).

\section{III.5.5 Ruído}

É fundamental que sejam abolidos ruídos intermitentes, pois estes aumentam significativamente a reabsorção fetal e os índices de canibalismo. Sons constantes e estáveis dentro da caixa tolerados pelos animais não são prejudiciais.

O som é uma das variáveis mais importantes do meio ambiente em biotérios. Nestes ambientes os ruídos originam-se de diversos fatores, tais como vocalização de pessoas e dos próprios animais, operações de limpeza e de alimentação, funcionamento de equipamentos, bater de portas, dentre outros. Avaliam-se os ruídos pela intensidade, que é medida em decibéis ( $d B)$ e, pela freqüência (agudeza do som), que é medida em Hertz $(\mathrm{Hz})$. As freqüências inaudíveis ao homem são chamadas de infra-som (baixas) (sons graves) e ultrasom (altas) (sons agudos). A maioria dos animais, incluindo os animais de laboratório, ouve sons de freqüências superiores àquelas audíveis pelo homem (FLETCHER; MC SHEELY, 1976). Tanto o homem quanto os animais apresentam, dentro de suas faixas de freqüências de audição, as chamadas faixas de sensibilidade, ou seja, um ou mais intervalos de freqüência nos quais é maior a percepção da intensidade do som. Quando o ruído atinge níveis acima do tolerado, principalmente em roedores, provoca estresse, que pode ser observado pelas mudanças no comportamento, podendo levar a convulsões e até a morte.

Geralmente, em salas habitadas por roedores, é encontrado nível de 50 dB. O nível de ruído aceitável é de até 85 decibéis (SANTOS, 2006). No entanto, níveis de ruído duradouro de $94 \mathrm{~dB}$ ou mais, são prejudiciais ao ouvido humano. Sabe-se pouco sobre os níveis de ruído que causam dano permanente aos animais (VALERO et al., 1990). 
Mudanças em padrões de exposição sonora produzem efeitos distintos em animais diferentes (Armário et al., 1985, Clough, 1982), pessoas que trabalham com animais devem tentar evitar, produção de ruído desnecessário. Os ruídos excessivos ou intermitentes podem ser diminuídos com o treinamento de pessoal e com equipamentos capazes de absorver choques (NRC, 2003).

Podemos observar as diferenças de sensibilidade auditiva entre as distintas espécies, inclusive no homem (TAB. 5). A faixa de sensibilidade humana é muito mais baixa quando comparada com a do rato, confirmando assim a grande sensibilidade desses animais em relação a ruídos.

TABELA 5 - Intervalo de freqüência e faixa de sensibilidade auditiva de algumas espécies.

\begin{tabular}{ccc}
\hline Espécies & $\begin{array}{c}\text { Faixa auditiva } \\
(\mathbf{d B})\end{array}$ & $\begin{array}{c}\text { Faixa de } \\
\text { Sensibilidade (dB) }\end{array}$ \\
\hline Camundongo & 0,75 a 85 & 10 a 65 \\
\hline Hamster & 0,35 a 60 & 1 a 10 \\
\hline Rato & 0,1 a 65 & 35 a 40 \\
\hline Cobaia & 0,1 a 35 & 0,2 a 1 \\
\hline Coelho & 0,1 a 40 & 0,7 a 5 \\
\hline Homem & 0,02 a 20 & 0,7 a 8
\end{tabular}

Fonte: ((MERUSSE; LAPICHIK, 1996) apud MEZADRI et al., 2004).

Instalações eficazes para a criação e o manejo de animais de pesquisa são essenciais para o bem estar do animal, devendo proporcionar um ambiente adequado, para que eles cresçam, se reproduzam e mantenham boa saúde, o que é fundamental para a qualidade dos dados de pesquisa e para os programas de pesquisa e ensino nos quais os animais são utilizados. 


\section{III.6 Arquitetura em biotérios}

Nos itens anteriores, cuidou-se para que fossem enfatizados os diversos fatores que influenciam a qualidade do animal de laboratório. Contudo, o enfoque deste trabalho são os aspectos arquitetônicos presentes em uma instalação dedicada à criação de animais de laboratório.

Como os animais reagem às variações ambientais, seu comportamento e fisiologia mudam, os quais, por sua vez, podem causar variações significativas nos resultados da pesquisa. Por estas razões, instalações para criação de animais de laboratório devem ser projetadas, mantidas e operadas de forma a reduzir tanto quanto possível a ativação destes mecanismos de resposta do animal. Um primeiro requisito é que, para reduzir essas variações comportamentais e fisiológicas ambientalmente induzidas, as instalações para animais dedicados à pesquisa devem ser separadas de quaisquer outras instalações para acomodação animal e outros tipos de pesquisa.

Além dos requisitos para um controle ambiental acurado, as instalações de animais de laboratório deveriam ser projetadas para maximizar a facilidade de gerenciamento. Padrões de fluxo de tráfego deveriam maximizar o acesso conveniente para aqueles autorizados a usar a instalação e para movimento eficiente dos animais, suprimentos e rejeitos entre a instalação e pontos de recebimento e remoção, bem como no interior de todos os componentes da instalação. Características de projeto e acabamentos superficiais deveriam proporcionar a efetiva sanitização de todas as áreas da instalação, proporcionando um ambiente de trabalho seguro.

Exemplificando, embora as superfícies do piso devam permitir efetiva sanitização, elas não devem ser escorregadias quando úmidas; do mesmo modo, interruptores elétricos e dispositivos devem ter um projeto apropriado para prevenir riscos de choque para o pessoal, utilizando produtos de limpeza líquidos nas paredes e teto. Se forem utilizados projetos com corredor duplo, os padrões de fluxo de tráfego devem ser bem estabelecidos para prevenir a contaminação cruzada e estimular a cooperação do usuário (RUYS, 1991). 
Portanto, a estabilidade do ambiente é de importância fundamental para reduzir tanto quanto possível mudanças fisiológicas e comportamentais dos animais, evitando comprometimento dos dados experimentais. Dessa forma, o enfoque desse trabalho é identificar e modificar, do ponto de vista arquitetônico, os fatores ambientais inadequados existentes no Biotério do IPEN.

A biossegurança, como foi descrita anteriormente, é de extrema relevancia na edificação de ambientes destinados a área de saúde. Em relação aos biotérios, o ambiente a ser construído deve atender aos níveis adequados de biossegurança para proporcionar boas condições de trabalho, devendo ser adotado como princípio básico a aplicação de medidas de prevenção e controle de riscos para a saúde das pessoas, dos animais e para o meio ambiente.

Nos biotérios, onde o risco biológico é previsto, faz-se necessária a instalação de barreiras de contenção como antecâmaras e autoclaves de duas portas, para resguardar a integridade dos funcionários, da comunidade e do meio ambiente contra agentes infecciosos que possam ser liberados acidentalmente, e também garantir a qualidade dos resultados da pesquisa. Portanto, na execução do projeto de arquitetura e engenharia é fundamental que essas barreiras de contenção sejam consideradas, pois servem para separar as áreas contaminadas das outras dependências e limitar a ação dos agentes potencialmente perigosos e riscos de contaminação.

De maneira geral, para que um projeto seja executado com qualidade é necessário que os princípios de segurança sejam incorporados nas instalações físicas e também que sejam analisados os detalhes das tarefas a serem realizadas no ambiente de trabalho e com isso, definidos o layout adequado ao desempenho das técnicas, os acessos, os fluxos e outras instalações necessárias à operação segura do laboratório (PESSOA et al., 2008).

Pessoa (2004) adverte que devem ser considerados alguns pontos, quando se enfoca a biossegurança sob o ponto de vista de projetos de espaços para pesquisa biomédica, tais como: 
- Análise, antes da elaboração das plantas de arquitetura, do microorganismo que será manipulado no laboratório/biotério, no que diz respeito à classe de risco que este oferece para que possa ser determinado o nível de biossegurança.

- Elaboração do mapeamento de risco, com a finalidade de assegurar que os locais onde se manipulam microorganismos de risco mais elevado, estejam localizados em áreas protegidas e em pavimentos baixos.

- Verificação e quantificação, antes do dimensionamento dos laboratórios biomédicos e biotérios de experimentação, do número de pessoas que irão trabalhar e quais os tipos de animais que serão utilizados nas pesquisas.

- Dimensionamento dos espaços de maneira funcional e prática proporcionando melhor controle de contaminação e evitando que a manutenção destas áreas controladas seja excessivamente cara.

- Estudo dos fluxos de acesso, de maneira a favorecer a saída de pessoas em situações de emergência.

- Consulta a técnicos, pesquisadores e profissionais da área, a fim de se elaborar levantamento de dados para garantir que o fluxo de trabalho seja rigorosamente obedecido, que a execução das tarefas aconteça nos locais adequados, que os equipamentos como Cabine de Segurança Biológica - CSB, autoclaves, etc. sejam devidamente instalados e que os sistemas de infra-estrutura atendam a todas as necessidades, como por exemplo, equipamentos que não podem ser desligados estejam ligados à rede elétrica de emergência e à emergência do gerador.

Todos os cuidados específicos adotados na fase inicial do projeto é que irão evitar grande parte dos problemas detectados na execução, uso e manutenção das edificações, pois nas áreas que contém risco biológico os 
patógenos estão presentes nas amostras e conseqüentemente no ambiente de trabalho, podendo causar danos à saúde das pessoas envolvidas nessa área. É fundamental que um projeto arquitetônico nessa área combine as condições adequadas de sobrevivência dos animais, de segurança e as necessidades de conforto ambiental conveniente aos trabalhadores. Para alcançar essas condições arquitetônicas é importante adotar como princípio a busca constante da qualidade e da evolução tecnológica.

Para contribuir no controle de contaminação, as instalações do biotério de experimentação devem estar localizadas no prédio em área separada das demais. É necessário que o biotério esteja isolado de outros laboratórios e que o fluxo interno obedeça a um sentido unidirecional em função da seqüencia de atividades. Outro item importante para contribuição de um adequado funcionamento do biotério é a instalação da quantidade mínima de acessos ou aberturas externas, no entanto recomenda-se entradas independentes para acesso de pessoal, de animais e de serviços como equipamentos, ração, maravalha, etc.

A estrutura física funcional de um biotério pode ser resumida em três áreas distintas, sendo uma administrativa, uma de animais/vestiários e outra de infraestrutura. A área administrativa deve controlar a entrada do biotério, devendo estar localizada na área que antecede às salas dos animais. Na recepção, limitase a entrada de pessoas estranhas ao local, impedindo que seja levada contaminação externa para os animais e também evitando que as pessoas se contaminem e possam espalhar o microorganismo pelo meio ambiente. Nesse local também é feita a programação com antecedência do uso da sala de experimentação para serem utilizadas pelos técnicos e pesquisadores. Nessa área também se encontram as salas do bioterista responsável pelo biotério, a sala dos técnicos e a do veterinário.

A copa é um local destinado para as pessoas que trabalham na área e também para evitar que as refeições sejam feitas em local inadequado, como por exemplo, na área dos laboratórios. Com a finalidade de atender a área administrativa, os banheiros devem ser instalados independentes dos vestiários. 
A área do almoxarifado será destinada ao armazenamento de materiais referentes à administração. Na área de animais/vestiários as pessoas se preparam para entrar e/ou sair do biotério, é uma área transitória. É o local de assepsia dos técnicos e pesquisadores antes de entrarem e de uma descontaminação prévia antes de saírem, é a principal barreira física para as pessoas. A circulação com controle de contaminação é a área que antecede a sala de animais denominada de circulação de distribuição, ou seja, não contaminada. É uma área estéril onde são recebidas as pessoas, alimentos e utensílios após serem realizados os procedimentos de esterilização e higienização prévias. A circulação de recolhimento, ou seja, não descontaminada se encontra após a sala dos animais. É onde se recolhe todos os dejetos, cruzam objetos e pessoas que saem da sala de animais sem uma prévia desinfecção.

A sala de animais é o local destinado à acomodação dos animais de experimentação, onde é necessária a manutenção diária dos mesmos. Nessa área os animais são separados tanto por espécie como por tipo de patógeno. A temperatura, umidade, renovação e filtragem do ar são controladas nessas salas de modo que os animais sejam mantidos em ambiente adequado. A sala de procedimentos é o local onde são feitos os procedimentos de pesquisa com os animais. Nesse ambiente deve-se prever a instalação de equipamento de proteção coletiva (EPC) como, por exemplo, a Cabine de Segurança Biológica CSB.

$\mathrm{Na}$ área administrativa de infra-estrutura é onde estão reunidas as atividades referentes aos serviços de recebimento de animais, armazenamento, produtos e equipamentos, higienização, esterilização e descontaminação. A descontaminação é feita entre a circulação de recolhimento e a sala de higienização através de barreiras sanitárias, que ajudam na descontaminação dos utensílios através de autoclaves, guichê de passagem e tanque de imersão. $O$ depósito de materiais é o local onde se estocam gaiolas, mamadeiras, detergentes e outros materiais para uso e reposição. O depósito de resíduos, é o ambiente onde devem ser embalados adequadamente os excrementos, carcaças, tecidos e outros rejeitos provenientes das atividades de experimentação animal, conservados em refrigeradores/congeladores para posterior descontaminação e 
para o fim ao qual se destina. Deve-se prever uma sala para estoque de ração e estoque de maravalha. O laboratório de controle de qualidade é o ambiente destinado a verificar e monitorar o estado sanitário ou a saúde animal. A recepção/quarentena é a área destinada ao recebimento e acomodação dos animais procedentes de outros biotérios. O local das antecâmaras para passagem de equipamentos é importante, pois os equipamentos quando precisam de manutenção precisam passar por processo de descontaminação química antes de sair do biotério.

Cabe ressaltar que no biotério de experimentação, o fluxo de trabalho deve ser rigorosamente obedecido e o sistema de ar condicionado deve ter um tratamento especial, de maneira a deixar a área não descontaminada estanque em relação às outras (PESSOA et al., 2008). Com relação aos requisitos conforme o nível de biossegurança animal, recomenda-se os seguintes parâmetros, conforme resumo (TAB. 6). 
TABELA 6 - Resumo dos Requisitos Conforme o Nível de Biossegurança animal.

\begin{tabular}{|c|c|c|c|c|}
\hline Requisitos & NBA1 & NBA2 & NBA3 & NBA4 \\
\hline Isolamento do Biotério & - & - & $\mathrm{R}$ & O \\
\hline Indicação com símbolo de risco biológico & $\mathrm{O}$ & $\mathrm{O}$ & $\mathrm{O}$ & $\mathrm{O}$ \\
\hline Biotério isolado de passagens públicas & O & $\mathrm{O}$ & $\mathrm{O}$ & $\mathrm{O}$ \\
\hline $\begin{array}{l}\text { Lavatório próximo à entrada/saída da sala de animais } \\
\text { para lavagem de mãos }\end{array}$ & O & $\mathrm{O}$ & $\mathrm{O}^{*}$ & - \\
\hline $\begin{array}{l}\text { Lavatório próximo à entrada/saída da sala de } \\
\text { procedimentos para lavagem de mãos }\end{array}$ & O & O & O & - \\
\hline Torneira com acionamento sem o uso das mãos & - & $\mathrm{R}$ & $\mathrm{O}$ & - \\
\hline Janelas vedadas & $\mathrm{R}$ & $\mathrm{O}$ & - & - \\
\hline $\begin{array}{l}\text { Portas de entrada e saída das salas de animais com } \\
\text { intertravamento }\end{array}$ & $\mathrm{R}$ & $\mathrm{O}$ & $\mathrm{O}$ & O \\
\hline $\begin{array}{l}\text { Paredes, tetos, portas e pisos lisos, impermeáveis e } \\
\text { resistentes à desinfeç̧ão }\end{array}$ & $\mathrm{O}$ & $\mathrm{O}$ & $\mathrm{O}$ & O \\
\hline $\begin{array}{l}\text { Autoclave } \\
\text { - no biotério } \\
\text { - de duas portas }\end{array}$ & $\begin{array}{l}R \\
-\end{array}$ & $\begin{array}{l}\mathrm{O} \\
\mathrm{R}\end{array}$ & $\begin{array}{l}\mathrm{O} \\
\mathrm{O}\end{array}$ & $\begin{array}{l}\mathrm{O} \\
\mathrm{O}\end{array}$ \\
\hline $\begin{array}{l}\text { Ventilação mecânica, sem recirculação do ar para } \\
\text { outras áreas }\end{array}$ & O & O & O & $\mathrm{O}$ \\
\hline $\begin{array}{l}\text { Filtro HEPA (ar particulado de alta resistência) nas } \\
\text { saídas de ar }\end{array}$ & - & - & $\mathrm{O}^{*}$ & $\mathrm{O}$ \\
\hline Pressão negativa na sala de animais & $\mathrm{R}$ & $\mathrm{R}$ & O & $\mathrm{O}$ \\
\hline $\begin{array}{l}\text { Antecâmara de acesso ao biotério } \\
\text { - com lavatório e local para jalecos } \\
\text { - dotada de portas com intertravamento } \\
\text { - pressurizada com chuveiro e vestiário } \\
\text { - para equipamentos }\end{array}$ & $\begin{array}{l}R \\
- \\
- \\
R\end{array}$ & $\begin{array}{l}0 \\
- \\
- \\
0\end{array}$ & $\begin{array}{l}\mathrm{O} \\
\mathrm{O} \\
\mathrm{R}^{*} \\
\mathrm{O}\end{array}$ & $\begin{array}{l}- \\
0 \\
0 \\
0\end{array}$ \\
\hline $\begin{array}{l}\text { Separação física dos corredores de acesso às salas de } \\
\text { animais }\end{array}$ & - & $\mathrm{R}$ & O & $\mathrm{O}$ \\
\hline Tratamento de efluentes & - & - & $\mathrm{O}$ & $\mathrm{O}$ \\
\hline $\begin{array}{l}\text { Vedação de frestas nas paredes, tetos, pisos e demais } \\
\text { superfícies }\end{array}$ & - & $\mathrm{R}$ & $\mathrm{O}$ & $\mathrm{O}$ \\
\hline Cabine de Segurança Biológica (CSB) & - & $\mathrm{R}$ & $\mathrm{O}$ & $\mathrm{O}$ \\
\hline $\begin{array}{l}\text { Local destinado ao processo de descontaminação } \\
\text { higienização-preparo-esterilização }\end{array}$ & $\mathrm{R}$ & $\mathrm{O}$ & O & O \\
\hline
\end{tabular}

$\mathrm{R}=$ Recomendável. $\mathrm{O}=$ Obrigatório. Filtro HEPA: retém partículas $\geq 0,3 \mu \mathrm{m}$ [21]. * $\mathrm{A}$ avaliação de risco deve preceder a determinação dos níveis de biossegurança e medidas de contenção a serem adotadas, considerando, além da espécie animal, o risco potencial do agente, as atividades do biotério e as condicionantes locais. (Fonte: Vieira et alii, 2005) (PESSOA et al., 2008; OMS, 2004) apud Molinaro et al. 


\section{III.6.1 Materiais de construção utilizados em biotérios}

Os materiais e revestimentos utilizados em biotérios devem ser especificados levando-se em consideração os requisitos de biossegurança. É necessário fazer uma pesquisa sobre o desempenho do material antes da escolha, para certificar que a construção consiga um padrão aceitável de qualidade, pois o material escolhido vai ajudar a controlar a assepsia, facilitar a limpeza e a manutenção dos ambientes, principalmente nas áreas destinadas aos animais e que envolvem riscos.

Em relação às paredes, devem ser lisas, impermeáveis, sem reentrâncias, rachaduras e fendas. Todos os encontros entre as paredes e das paredes com o piso e com o teto devem ser com cantos arredondados e nivelados, para que não haja desníveis que dificulte a limpeza e sirva de acúmulo de sujidades. A pintura deve ser resistente a produtos químicos e também a lavagem com pressão e a calor moderado, em cores claras e foscas. É aconselhável adotar medidas de proteção contra impactos e possíveis danos decorrentes de batidas de carrinhos e equipamentos sob rodízios.

No que diz respeito ao piso, devem ser nivelados, contínuos, sem reentrâncias, lisos, porém não escorregadios, impermeáveis, não porosos e resistentes a agentes químicos (detergentes, desinfetantes, ácidos, etc.), para facilitar a higienização e a desinfecção. $O$ piso deve ser calculado de forma a resistir ao peso dos equipamentos e materiais, para não apresentar deformações ou rachaduras. Se houver quinas salientes nas alvenarias e piso, deverão ser protegidas com cantoneiras de material resistente a impactos.

Os tetos devem ser planos, devidamente vedados, impermeáveis, não porosos, com vedação contínua e sem reentrâncias, revestidos de materiais laváveis, resistentes a gases, produtos químicos e à lavagem com água sob pressão e ao calor moderado. As luminárias devem ser vedadas na sua parte inferior e instaladas no mesmo nível do teto, evitando reentrâncias e superfícies irregulares para evitar o acúmulo de sujidades. 
As portas de acesso aos ambientes laboratoriais, lavagem, esterilização e almoxarifado devem ter largura mínima de 1,10m e as portas de acesso das outras áreas do laboratório devem ter largura mínima de 0,80m. Deve ser de material lavável, resistente a agentes químicos, sem porosidade, que não desprendam partículas, que estejam adequadamente instaladas para seu perfeito fechamento e ajustadas no vão para evitar frestas.

Para facilitar a visualização dos ambientes como salas e circulações é recomendável que sejam instalados visores faceando a superfície das portas, sendo bem vedados para evitar frestas e reentrâncias. O sentido de abertura das portas deve levar em conta os fluxos nas áreas laboratoriais no intuito de evitar acidentes e as maçanetas a serem utilizadas devem ser do tipo alavanca para permitir a abertura sem a utilização das mãos.

As janelas que puderem ser abertas deverão ser providas de tela contra a entrada de insetos. Nas salas de animais não é aconselhável à instalação de janelas, pois impossibilitam o controle do fotoperíodo e o controle da temperatura em instalações com ar condicionado. Caso existam janelas em outras áreas do biotério, é recomendável que não sejam abertas, que não tenham bordas ou superfícies horizontais para não acumular sujidades e dificultar a limpeza.

As bancadas devem ter altura de 0,90m para trabalhos que exijam posição de pé e altura de $0,75 \mathrm{~m}$ nas bancadas para trabalhos que exijam posição sentada e profundidade mínima de 0,70m nos dois casos. As superfícies das bancadas devem ser revestidas com materiais impermeáveis, lisos, sem emendas ou ranhuras para facilitar a limpeza e desinfecção. As cubas devem ter profundidade mínima de $0,25 \mathrm{~m}$. Normalmente, os biotérios utilizam bancadas e cubas em aço inoxidável.

O acesso às instalações prediais para efeito de manutenção deve estar localizado fora da área de criação ou experimentação animal, para que os técnicos não necessitem entrar nessas áreas. Quando as tubulações atravessarem paredes, pisos ou tetos de ambientes de contenção, os orifícios deverão ser vedados com produtos adequados. A drenagem de efluentes deve 
ser provida de sistema que impossibilite o refluxo de água, gases e a entrada de insetos e outros animais (PESSOA et al., 2008; FUNASA, 2004; OMS, 2004). Considerando o nível de biossegurança animal é apresentada a relação de materiais, conforme resumo (TAB. 7).

TABELA 7 - Relação de Materiais Considerando o Nível de Biossegurança Animal.

\begin{tabular}{|c|c|c|}
\hline Tipo & Discriminação & NBA \\
\hline \multirow[t]{3}{*}{ Estrutura das paredes/painéis } & Tijolo cerâmico & $1,2,3$ \\
\hline & Concreto celular & \\
\hline & Gesso acartonado & \\
\hline \multirow{3}{*}{$\begin{array}{l}\text { Revestimento } \\
\text { paredes/painéis }\end{array}$} & Pintura PVC & $1,2,3$ \\
\hline & Pintura acrílica & \\
\hline & Pintura epoxídica & 3 \\
\hline \multirow[t]{3}{*}{ Estrutura do teto } & Gesso acartonado & $1,2,3$ \\
\hline & Laje de concreto & \\
\hline & Laje pré-moldada & \\
\hline \multirow[t]{3}{*}{ Revestimento - teto } & Pintura acrílica & 1,2 \\
\hline & Pintura PVC & \\
\hline & Pintura epóxi & 3 \\
\hline \multirow[t]{4}{*}{ Revestimento - porta } & Pintura a óleo & $1,2,3$ \\
\hline & Laminado melamínico (fórmica) & \\
\hline & Alumínio & \\
\hline & Aço inoxidável & 3 \\
\hline \multirow{2}{*}{ Estrutura - janela } & Madeira com pintura a óleo & 1,2 \\
\hline & Alumínio anodizado ou natural & \\
\hline \multirow[t]{5}{*}{ Estrutura - visores } & Alumínio anodizado ou natural & 1,2 \\
\hline & Vidro simples & \\
\hline & Alumínio anodizado ou natural & 3 \\
\hline & Vidro duplo com vedação das & \\
\hline & frestas com silicone & \\
\hline
\end{tabular}

Fonte: pesquisa direta (PESSOA et al., 2008). 
Todas as considerações, normas e leis expostas acima serviram de base para o desenvolvimento do projeto de adequação do Biotério do IPEN, compatível com a arquitetura pré-existente e de acordo com os recursos orçamentários disponíveis, de modo a contemplar as exigências mínimas para a criação e manutenção de animais de laboratório com qualidade genética e sanitária controladas. 


\section{MATERIAIS E MÉTODOS}

Este trabalho consiste em três atividades principais:

- avaliação do estado da instalação, do ponto de vista arquitetônico;

- revisão dos seus diversos aspectos construtivos, de acordo com os princípios e recomendações existentes na literatura;

- elaboração de uma proposta de adequação para o biotério do IPEN.

Todo o estudo baseou-se na análise crítica e pormenorizada do biotério do IPEN, com objetivo de gerar uma proposta de adequação das instalações e procedimentos. Para tanto, confrontaram-se as informações coletadas a respeito da situação existente com aquelas obtidas da bibliografia. Também foram realizadas visitas a outros laboratórios semelhantes, além de intercâmbio de informações com os responsáveis/operadores dessas instalações. Finalmente, foi realizada uma busca de materiais e equipamentos alternativos junto aos respectivos fornecedores.

Desse modo, inicialmente, foi realizada uma revisão bibliográfica das principais normas aplicáveis e nas recomendações construtivas obtidas de organismos vinculados à criação de animais para pesquisa. Levaram-se em consideração as necessidades para garantir o bem-estar e manutenção dos animais com qualidade sanitária, bem como as condições adequadas de trabalho aos operadores. Foram alvo de consideração os seguintes aspectos:

- Bem-estar dos animais;

- Bem-estar dos operadores;

- Mapas de sinalização de fluxo na instalação;

- Melhoria das instalações, prevendo salas de treinamento e de descanso;

- Iluminação natural x lluminação artificial;

- Isolamento acústico;

- Modernização das salas de recepção e expedição dos animais; 
- Sala de armazenamento de ração;

- Adequação de sala de biossegurança e salas de experimentação;

- Seleção dos materiais mais adequados para revestimentos de pisos, paredes e portas;

- Sistema de ventilação;

- Vedação e estanqueidade dos ambientes;

- Análise da viabilidade de implantação de barreira de biossegurança para impedir contaminações.

\section{IV.1 Situação atual das instalações do Biotério do IPEN/CNEN-SP}

O projeto das instalações do Biotério do Instituto de Pesquisas Energéticas e Nucleares (IPEN), elaborado no ano de 1964, foi planejado com o objetivo de ser uma unidade de produção e manutenção de animais. Contudo, naquela época não havia as recomendações atuais no que diz respeito ao controle sanitário, genético e ambiental. Assim, o desenho original da unidade apresenta uma distribuição de área inadequada, que impossibilita a completa segregação de animais pós-ensaio, colônias de produção e estoque, bem como animais portadores de alterações em seu "background" genético.

\section{IV.1.1 Descrição das atuais instalações}

A instalação do biotério ocupa uma área de $840 \mathrm{~m}^{2}$, com um pavimento, onde estão distribuídas as áreas de produção e estoque de modelos animais originários da própria instituição, bem como a manutenção de animais oriundos de outras Instituições Nacionais e do exterior. Muitos dos modelos produzidos no IPEN são únicos no Brasil e constituem-se, portanto, em um importante patrimônio que deve ser preservado (NASCIMENTO, 2005).

\section{IV.1.2 Localização e usuários}

Localizada no Centro de Biotecnologia do IPEN, essa instalação também atende aos usuários da Diretoria de Radiofármacos do Instituto, fornecendo ratos 
e camundongos para os testes biológicos dos lotes dos radiofármacos produzidos, antes de serem enviados aos hospitais de todo o Brasil e também na utilização de animais para pesquisas de novos radiofármacos. Outros Centros do IPEN, bem como Instituições parceiras também utilizam diferentes espécies e linhagens criadas e/ou mantidas no Biotério do IPEN para desenvolvimento de pesquisas.

\section{IV.1.3 Principais problemas identificados nas instalações}

A experiência adquirida em Centros de Pesquisa dos países desenvolvidos e a experiência acumulada no próprio IPEN devem ser analisadas com vistas a corrigir as falhas no desenvolvimento arquitetônico das unidades, nos equipamentos instalados e nos procedimentos operacionais utilizados na manutenção dos animais (PASSOS, 2001).

Por ocasião da execução do projeto inicial do Biotério do IPEN, não foram levadas em consideração, de maneira mais rígida, as normas e os conceitos de biossegurança como barreiras sanitárias, restrição de acesso ao biotério, separação das áreas de criação e experimentação e fluxos.

No que diz respeito a infra-estrutura física, não foi dada a devida atenção à escolha dos materiais de construção, que hoje não são aceitos do ponto de vista sanitário, pois implicam em riscos à saúde dos profissionais que atuam nessa área, além de comprometer os animais, o meio ambiente e também a qualidade dos trabalhos desenvolvidos.

Este quadro propicia o surgimento de colônias de patógenos, uma vez que não é possível estabelecer satisfatoriamente rotinas de desinfecção, comprometendo a qualidade sanitária da instalação (NASCIMENTO, 2005). Atualmente, o Biotério do IPEN encontra-se com os revestimentos desgastados pelo uso e também com soluções de projeto que estão fora das normas adequadas ao bom funcionamento da instalação. 


\section{IV.1.4 Problemas identificados nas salas de criação}

Nas Salas de Criação de Animais as paredes são revestidas de azulejo (FIG.3), o que impede a higienização devido ao acúmulo de poeira nas juntas.

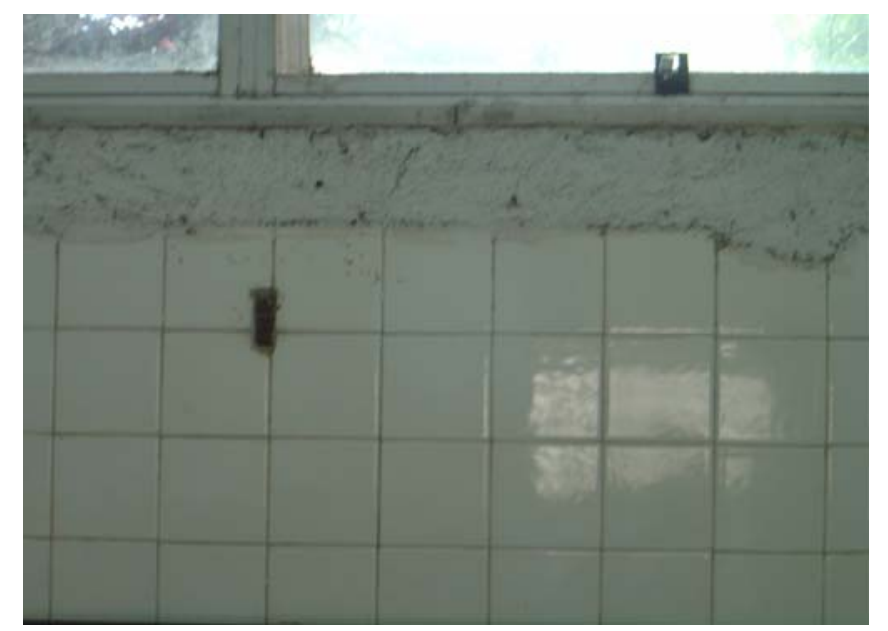

FIGURA 3 - Salas revestidas com azulejos no Biotério do IPEN.

As gaiolas ficam apoiadas em prateleiras feitas em concreto (FIG.4), instaladas em três níveis, no sentido longitudinal da sala. Essa solução não atende mais, aos novos conceitos de Biotério, devido ao fato do revestimento não ser adequado, pois propicia o acúmulo de sujeiras, dificultando também a higienização das salas.

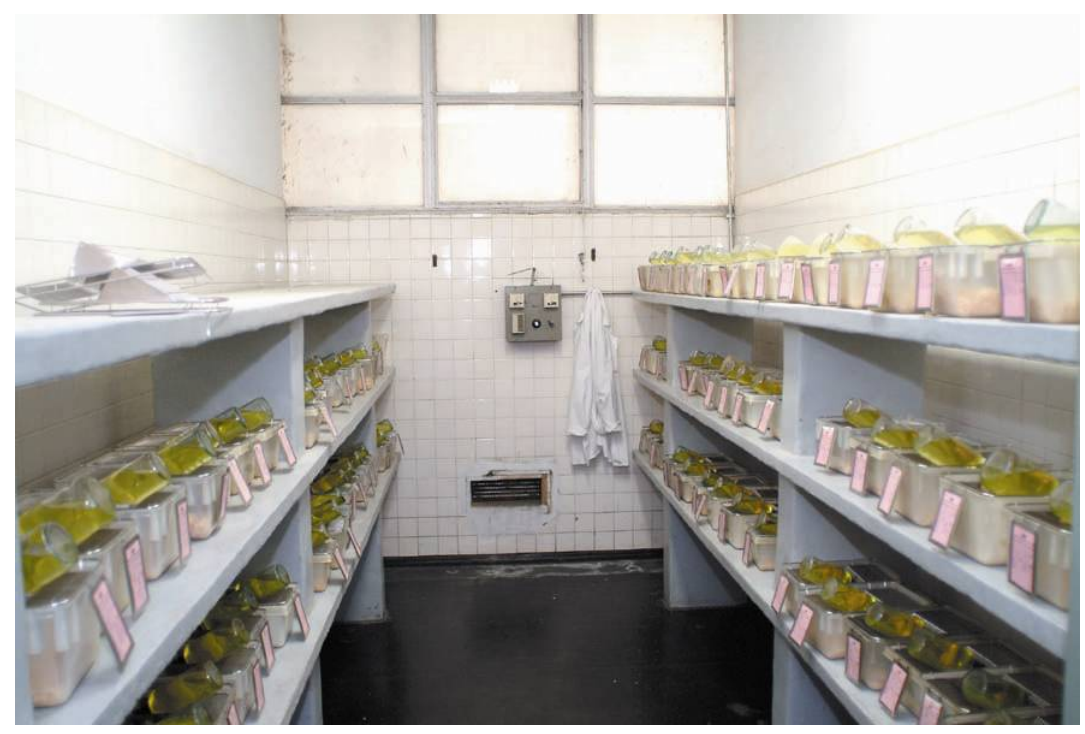

FIGURA 4 - Prateleiras existentes no Biotério do IPEN. 
Por serem prateleiras fixas, não há como resolver o problema do ar, que por não circular por sobre as gaiolas, não permite a adequada renovação do mesmo em seu interior, levando ao aparecimento de infecções pulmonares nos animais, em função das elevadas taxas de amônia. Adicionalmente, este tipo de prateleira limita o espaço na área da sala, não permitindo o aumento do número de animais produzidos (PASSOS, 2001). As janelas têm vidros comuns, o que significa a possibilidade de violação (FIG.5).

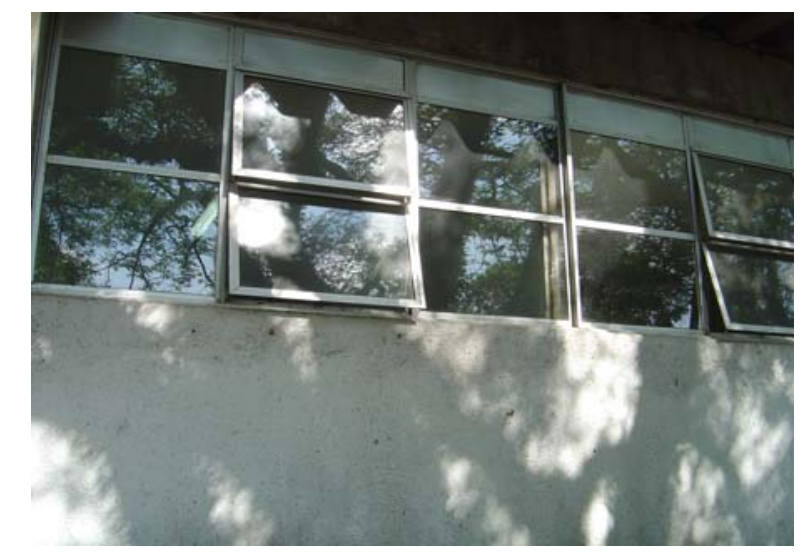

FIGURA 5 - Janelas com abertura para o exterior.

As portas em madeira com visor (FIG.6) estão bastante deterioradas devido aos cupins, com rachaduras, impossibilitando seu perfeito funcionamento e liberando partículas que contaminam a área e dificultam a higienização. Os visores das portas também não estão adequados, pois formam reentrâncias que acumulam poeira.

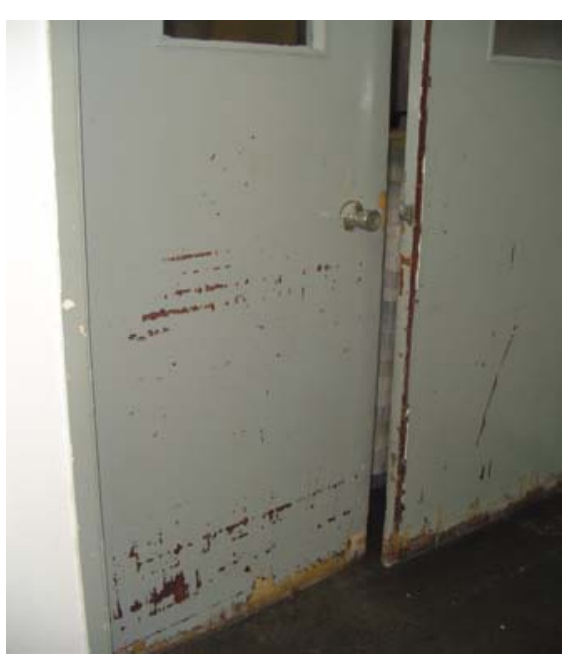

FIGURA 6 - Portas deterioradas. 
As luminárias de sobrepor (FIG.7) existentes nas salas dos animais, não são eficazes, pois as lâmpadas ficam expostas, sem proteção e propiciam o acúmulo de poeira, prejudicando a limpeza e atuando como mais um fator contaminante da área.

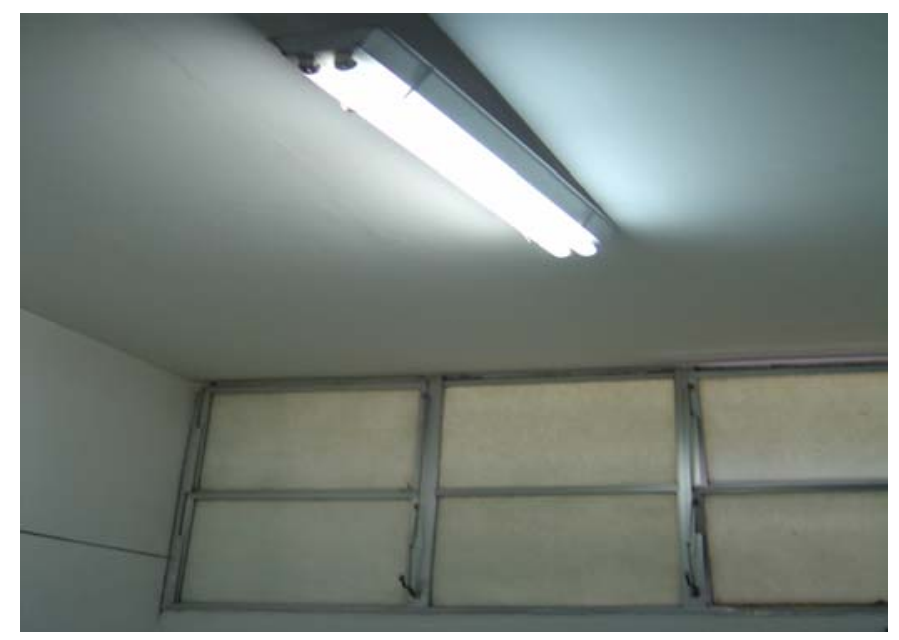

FIGURA 7 - Luminária de sobrepor existente.

O piso na área do biotério foi executado em granilite e atualmente encontra-se desgastado e com alguns remendos. Os encontros das alvenarias também não possuem cantos arredondados.

O teto existente foi executado em placas de gesso e se encontra com trincas, rachaduras e manchas, devido a vazamento de água, consistindo-se em foco de entrada de insetos e outras sujidades, o que torna mais difícil o controle da contaminação.

\section{IV.1.5 Problemas identificados nos acessos e áreas de circulação}

O acesso principal ao biotério (FIG.8) é feito por uma única porta, ligada diretamente ao exterior, expondo os animais, as pessoas e as atividades às condições do meio ambiente e contaminações, permitindo a entrada de insetos, poeira e contribuindo para uma difícil padronização sanitária das colônias. 


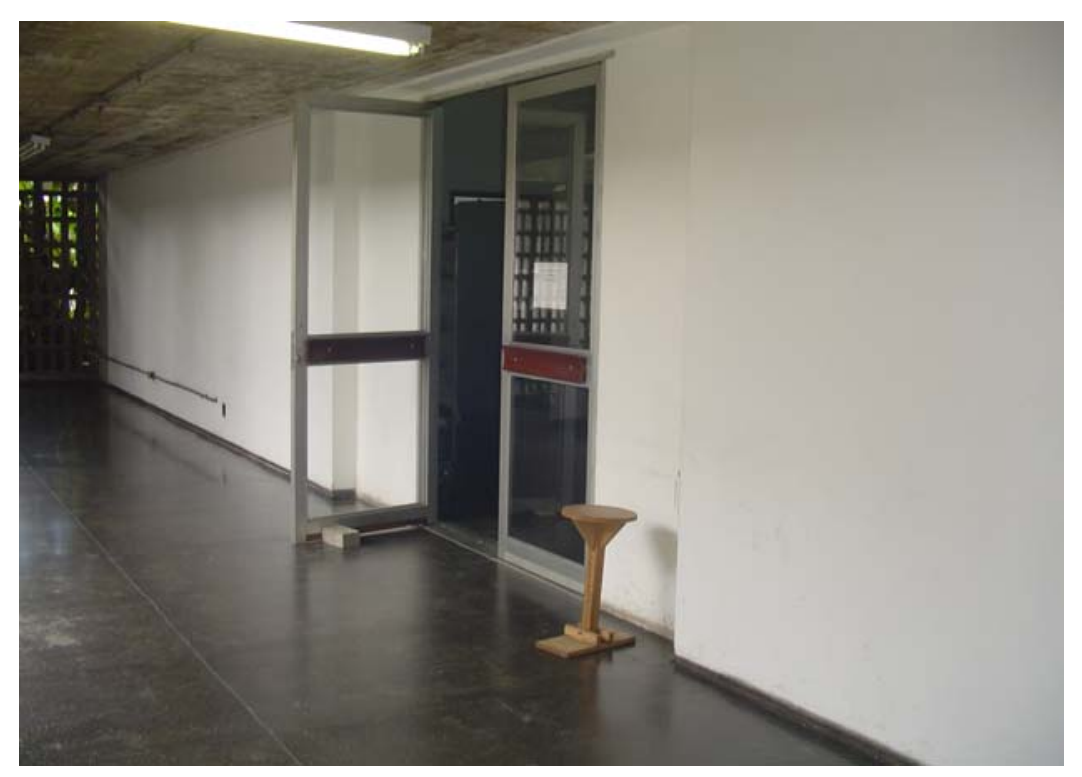

FIGURA 8 - Entrada principal do Biotério do IPEN.

Em toda a extensão das circulações, foi executado fechamento com elemento vazado em concreto (FIG.9), permitindo o contato direto com o exterior, a entrada de insetos, vento, poeira, o que dificulta a limpeza e impede que o ambiente seja higienizado.

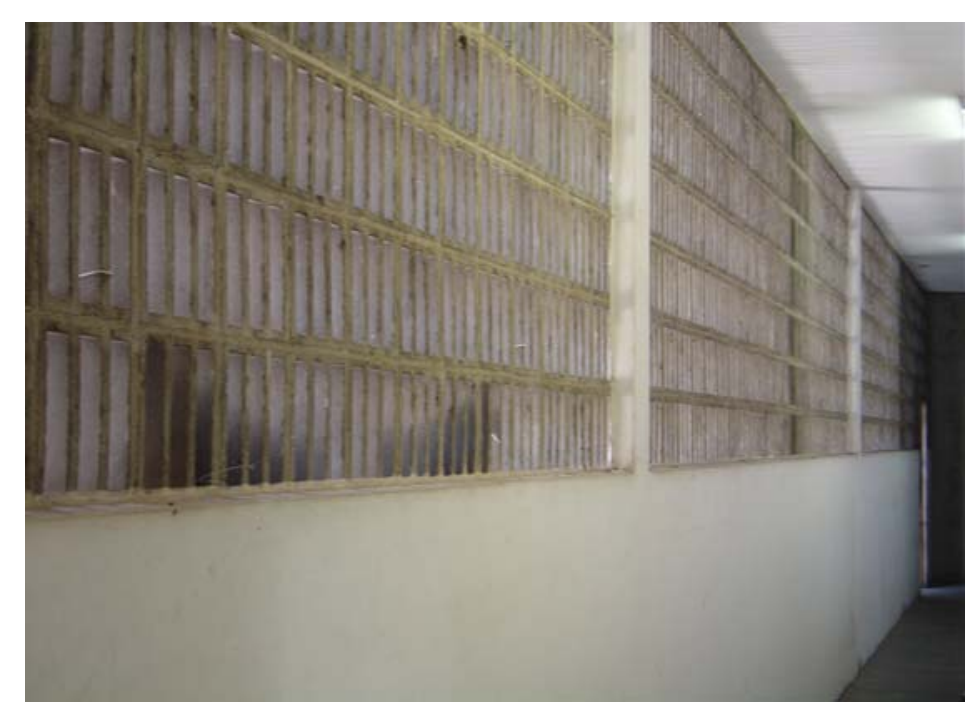

FIGURA 9 - Elemento vazado nas circulações do prédio 
Constam também, nessas circulações, ralos com grelhas (FIG.10) e aberturas na parte inferior das alvenarias (FIG.11), que contribuem para a exposição da área.

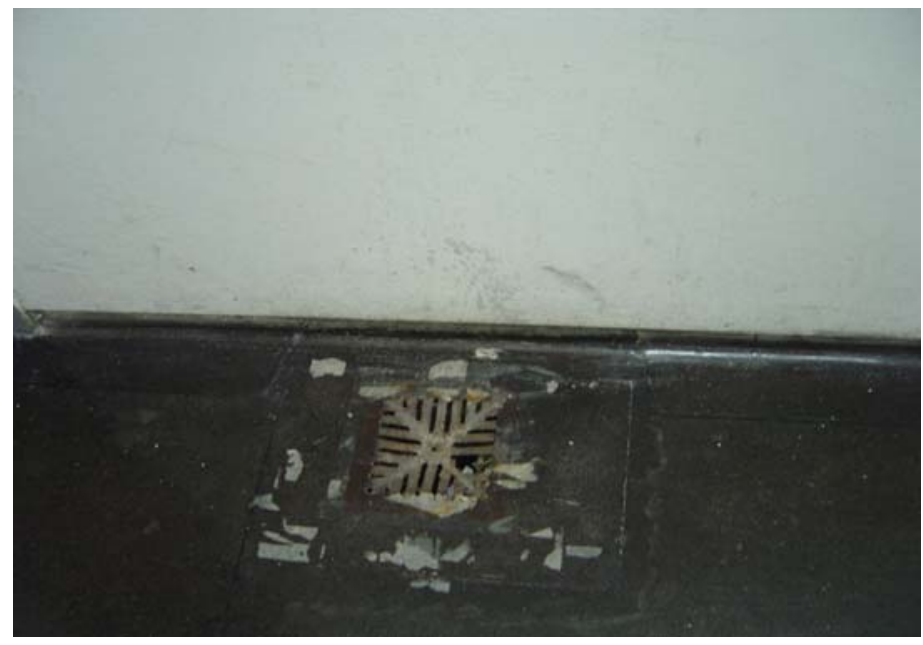

FIGURA 10 - Ralo com grelha existente no piso da circulação.

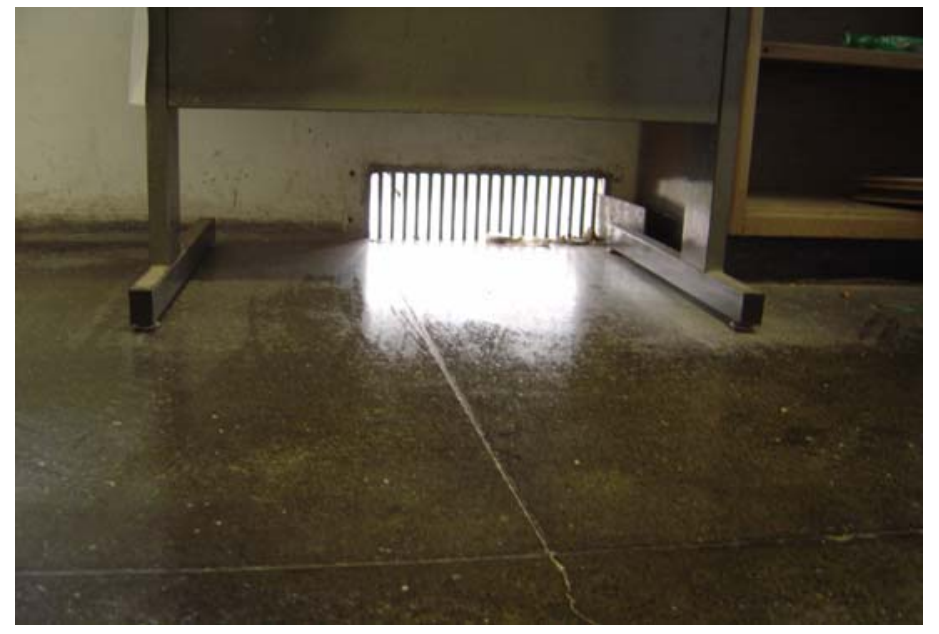

FIGURA 11 - Abertura na alvenaria.

Embora seja recomendado, não há vedação das janelas nas salas de experimentação (BRASIL, 2004). Devido à inexistência de um sistema de ar, é necessária uma atenção especial, pois existem diversos poluentes que devem ser removidos, sendo a amônia o mais importante, podendo interferir nos experimentos e também comprometer a qualidade de vida dos técnicos da área (PASSOS, 2001). 


\section{IV.1.6 Problemas identificados nas áreas de apoio}

Ao passarmos na porta de entrada do Biotério, a primeira sala que se via era destinada aos funcionários e na sala contígua estava a copa (FIG.12). Devido à proximidade com as áreas de trabalho, concluiu-se que ela estava instalada em local totalmente inadequado, segundo as práticas padrão descritas no Manual Técnico e Normas de Biossegurança em Laboratórios Biomédicos e de Microbiologia, temos que, para todos os níveis de biossegurança (BRASIL, 2004):

"Não é permitido comer, beber, fumar, manusear lentes de contato, aplicar cosméticos ou armazenar alimentos para consumo nas áreas de trabalho. As pessoas que usam lentes de contato em laboratórios deverão usar também óculos de proteção ou protetores faciais. Os alimentos deverão ser guardados fora das áreas de trabalho em armários ou geladeiras específicos para tal fim."

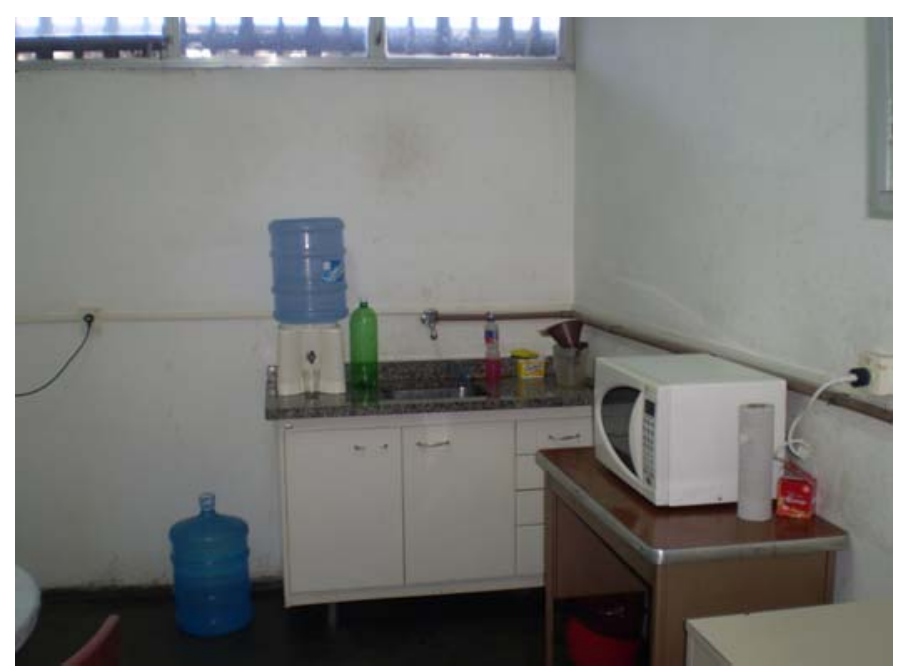

FIGURA 12 - Copa existente na área do Biotério do IPEN.

Na sala do Almoxarifado, sala que faz divisa com a copa, observavam-se frestas nas paredes, e no piso, além da instalação de janelas, sem proteção de tela contra insetos, que favoreciam contato direto com a área externa.

Em seguida, tínhamos a Sala de Estocagem de Maravalha (FIG.13) e na seqüência encontrava-se a Sala de Estocagem de Ração (FIG.14), ambas com janelas, o que não é recomendável (BRASIL, 2004). Somava-se a estes fatores a 
presença de cupins que inviabilizam a manutenção de um padrão sanitário eficiente.

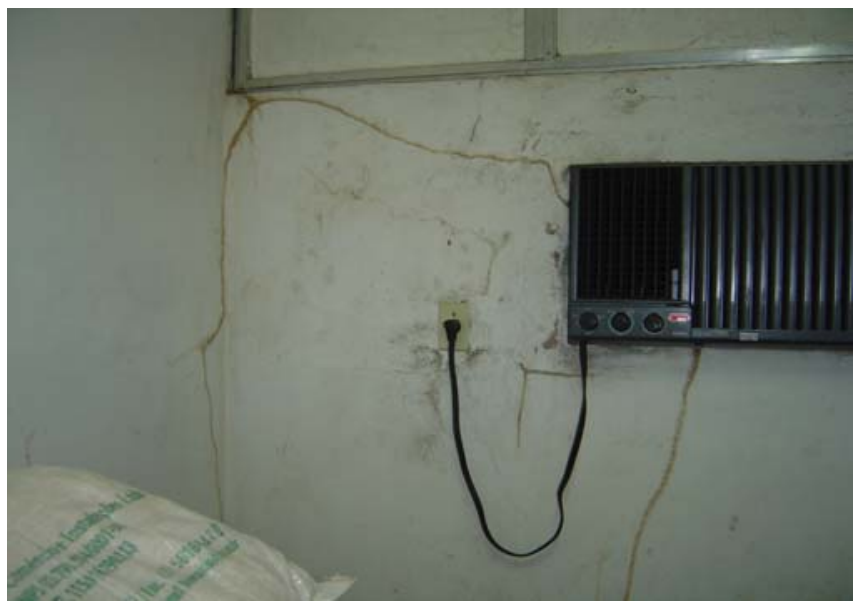

FIGURA 13 - Sala de Estocagem de Maravalha.

Cabe relatar que a estocagem de ração e maravalha não pode ter contato direto com o chão, pois devido a umidade, perderia sua capacidade de absorção, permitindo o crescimento de microorganismos. Devem ser colocadas em estantes, estrados ou carrinhos, para garantir sua qualidade e evitar contaminação.

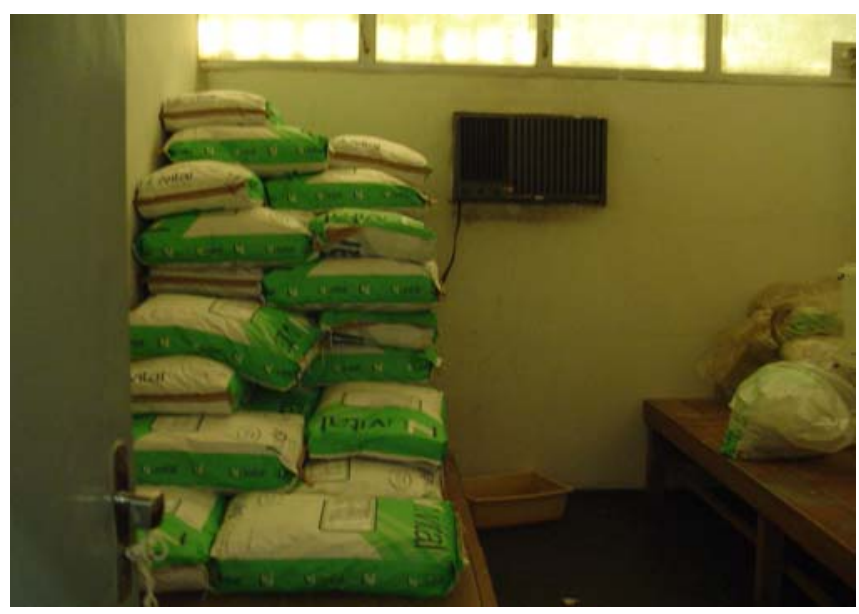

FIGURA 14 - Sala de Estocagem de Ração.

A Sala de Lavagem de Materiais compreende a área onde estão concentradas as atividades de higienização e esterilização dos materiais utilizados na manutenção das colônias dos animais. Na entrada da sala, existe 
uma canaleta com grelha em ferro na largura do vão da porta (FIG.15), o que ocasionou várias situações incompatíveis, como entupimento, refluxo de água, entrada de insetos, além de representar um ponto de contaminação constante na sala.

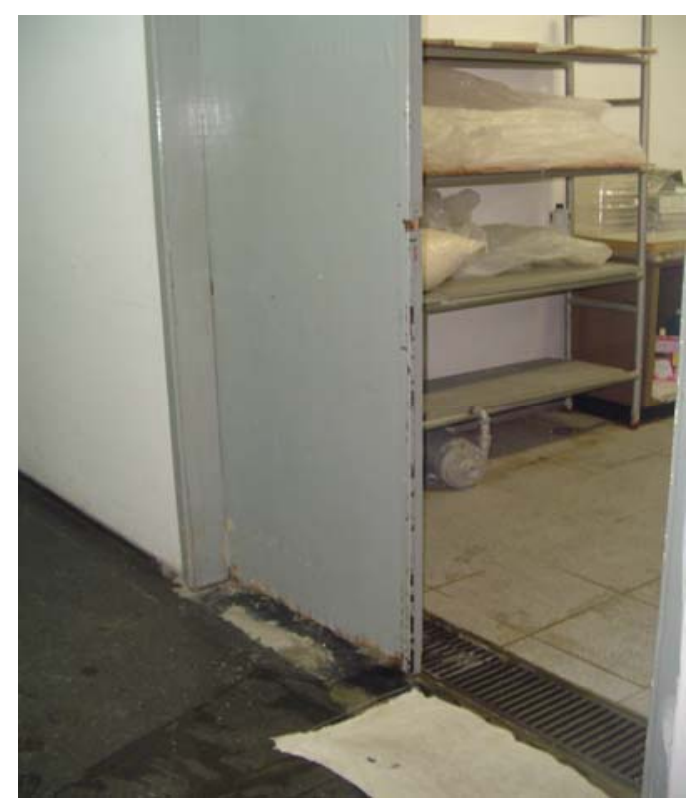

FIGURA 15 - Canaleta com grelha no piso.

Os tanques existentes na sala de lavagem, executados em concreto (FIG.16), apresentam atualmente inúmeras rachaduras, que impedem a perfeita desinfecção, comprometendo a qualidade da higienização dos materiais feita na sala.

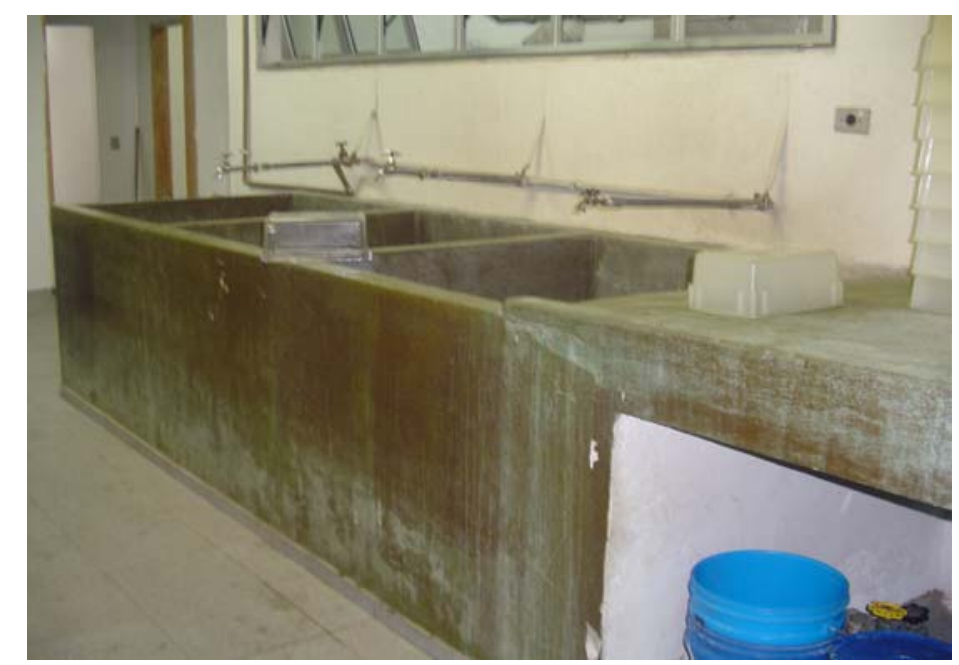

FIGURA 16 - Tanques existentes na Sala de Lavagem. 


\section{IV.2 Procedimentos atuais adotados nas instalações do Biotério do IPEN/CNEN-SP}

\section{IV.2.1 Procedimentos de acesso}

Durante o levantamento sobre as inadequações do Biotério, observou-se que existia um único acesso para funcionários, pesquisadores, animais, materiais e serviços. Além disso, não havia o controle de fluxo de pessoas nessa área, o que é fundamental para um bom funcionamento dessa instalação. Tal situação comprometia o correto funcionamento do Biotério, no que diz respeito aos conceitos de biossegurança, como descontaminação ambiental, desinfecção, eliminação de dejetos em condições de segurança, pois expunham os funcionários, os animais, os técnicos e as atividades de pesquisa a situações de risco.

O acesso para as Salas de Criação necessitava revisão, pois não havia local específico para higienização e paramentação dos bioteristas. Os biotérios devem possuir vestiários adequados, sendo recomendado trocar de roupa, tomar banho, paramentar-se com roupas esterilizadas, como macacão, avental, máscara, touca, luva, e a partir deste ambiente, acessar a área limpa ou asséptica.

A função das instalações com barreiras de contenção é excluir ou minimizar o risco de acidentes, uma vez que, nos biotérios, a contaminação é um fator importante em função das atividades que são desenvolvidas nessa área.

\section{IV.2.2 Procedimentos de limpeza e desinfecção}

A criação de animais implica, dentre outras atividades, em trocas das gaiolas ou mini-isoladores onde são mantidos. Para tanto, após a troca, os miniisoladores "sujos com a maravalha no fundo" (FIG.17) eram colocados sobre carrinhos, e levados para a sala de lavagem por um corredor (FIG.18). Neste corredor circulava também pesquisadores e funcionários do Biotério, o que não era recomendado, pois os carrinhos com os mini-isoladores "sujos com a 
maravalha" colocam em risco as pessoas, comprometiam a passagem da circulação e contaminavam a área. Contudo, o problema mais grave, do ponto de vista sanitário era o transporte do material limpo pelo mesmo corredor, dificultando a higienização e comprometendo as atividades de criação e experimentação animal.

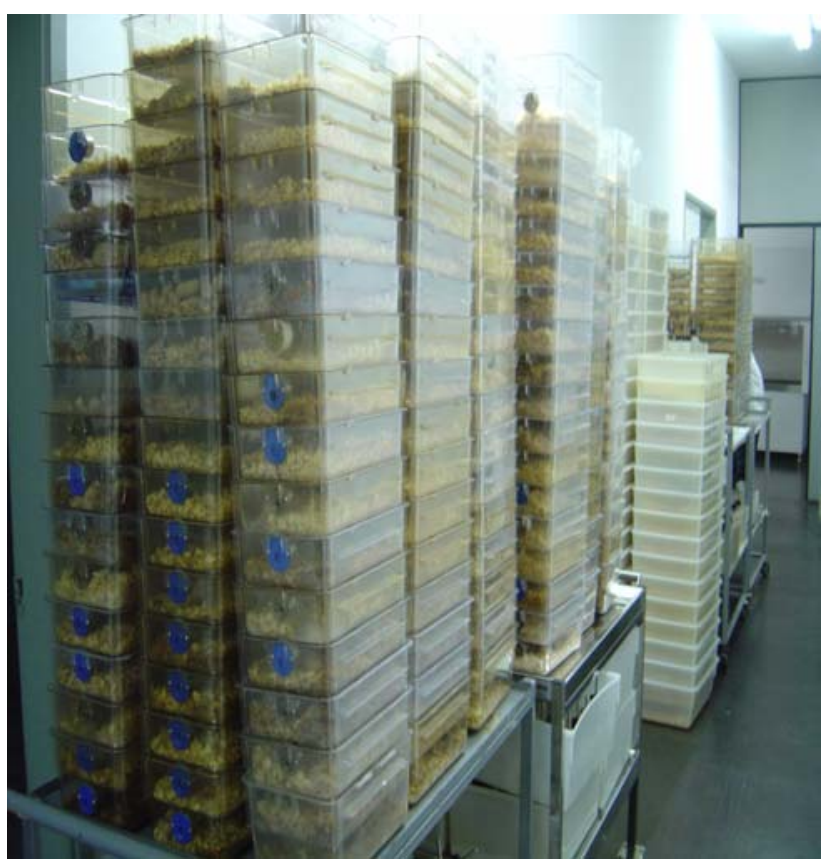

FIGURA 17 - Mini-isoladores "sujos"

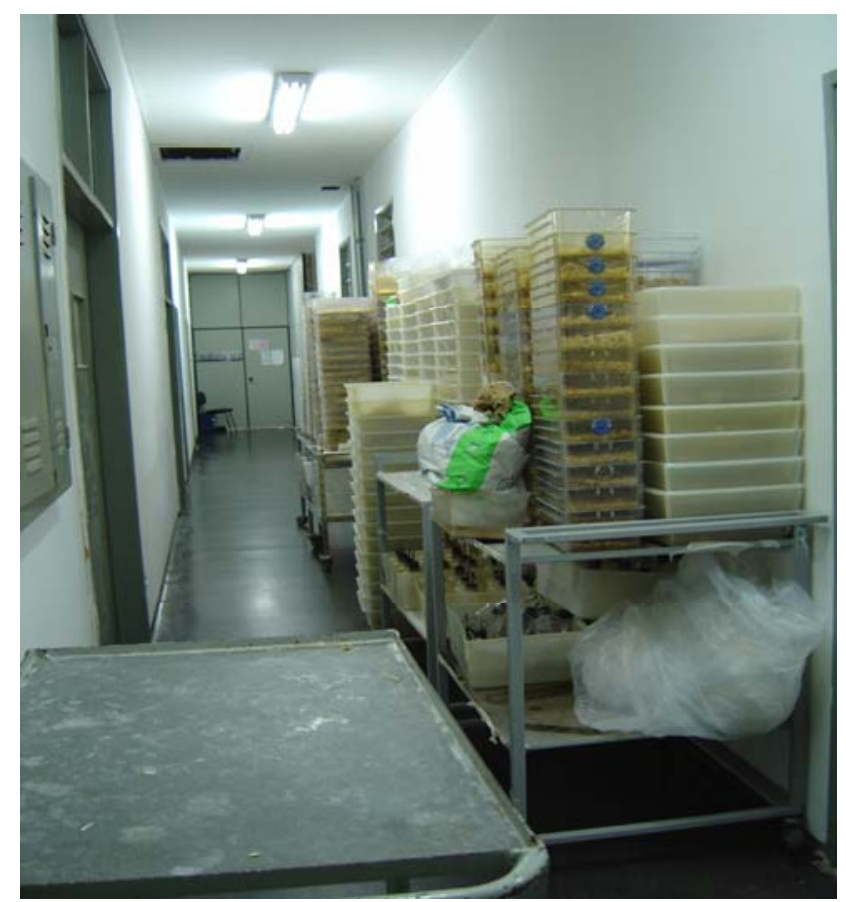

FIGURA 18 - Corredor 
$\mathrm{Na}$ sala de lavagem era efetuada a raspagem dos fundos dos miniisoladores, que em seguida ficavam imersos em solução para desinfecção, para então ser feita a lavagem, o enxágüe, a secagem e a embalagem em sacos plásticos para serem autoclavados, em uma das duas autoclaves existentes na sala. Depois de esterilizados, os materiais eram encaminhados pelo mesmo corredor, até uma ante-sala e posteriormente distribuído para as Salas de Criação.

\section{IV.2.3 Procedimentos de fluxo}

O fluxo na área do biotério não é adequado e não atende aos princípios de biossegurança, pois o local não está isolado com barreiras sanitárias eficazes, criando fluxo nos dois sentidos de funcionários, materiais, insumos e animais, o que inviabiliza a desinfecção do ambiente.

Também não existia um vestiário masculino próximo, para entrada direta na área de criação de animais. Os funcionários do sexo masculino que trabalham nessa área utilizavam o vestiário localizado distante da área de criação e com acesso pela circulação "suja" ou séptica, comprometendo significativamente a higienização. Ao final das atividades, os funcionários saíam da área, caminhavam pela mesma circulação, até o vestiário, retiravam a roupa utilizada nas atividades, tomavam banho e vestiam suas roupas pessoais. 


\section{RESULTADOS}

\section{V.1 Projeto da primeira etapa da adequação e reforma das instalações do Biotério do IPEN/CNEN-SP}

O projeto da reforma das instalações do Biotério do IPEN (FIG.19) está sendo realizado em etapas, conforme descrito a seguir. Para a primeira etapa da reforma (FIG.20) foram propostas diversas alterações. Contudo, devido às restrições orçamentárias decorrentes dos escassos recursos disponíveis, a complementação da reforma foi limitada, contemplando apenas alguns itens considerados prioritários, como as salas de criação.

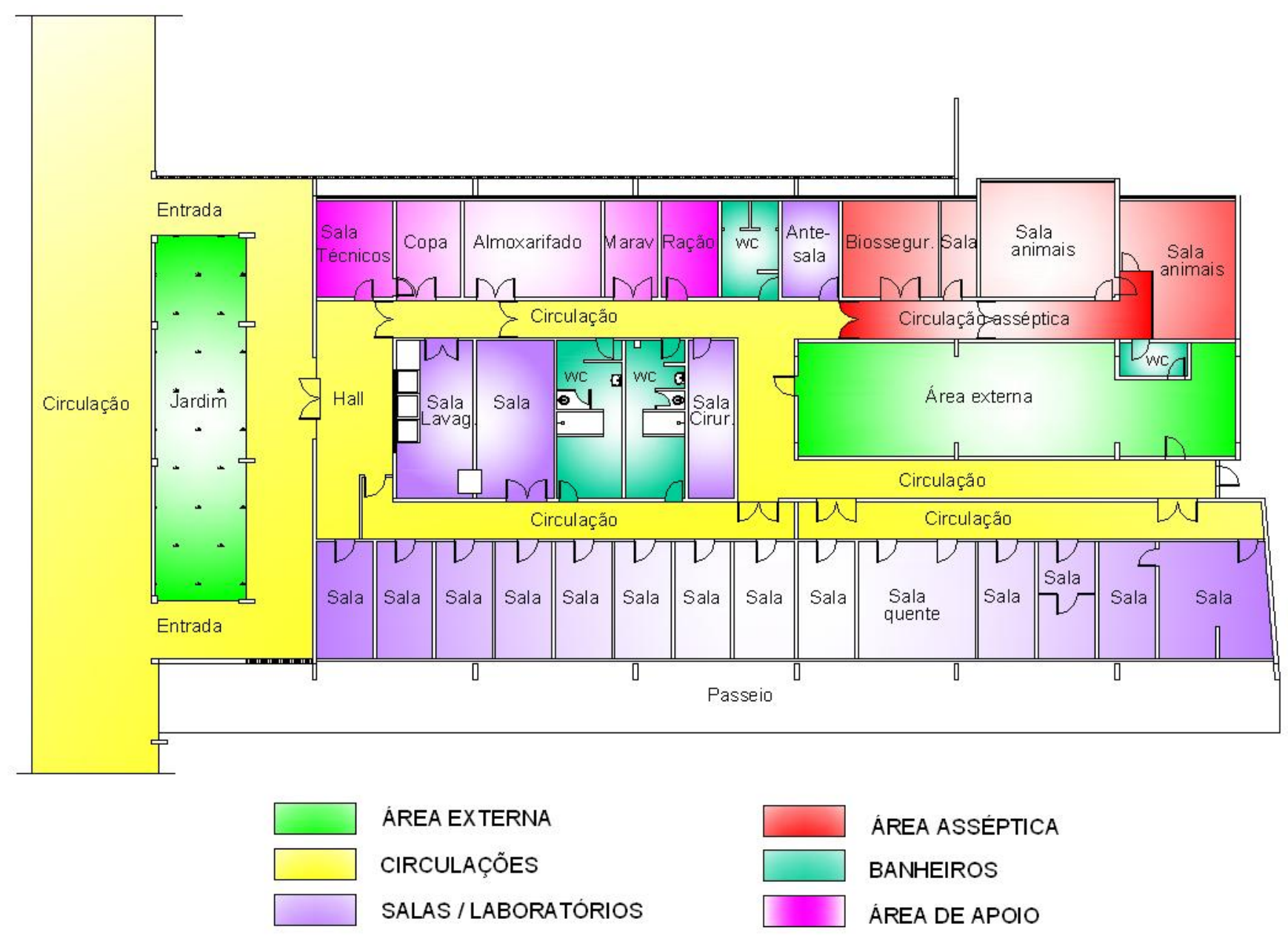

FIGURA 19 - Planta do Biotério do IPEN 


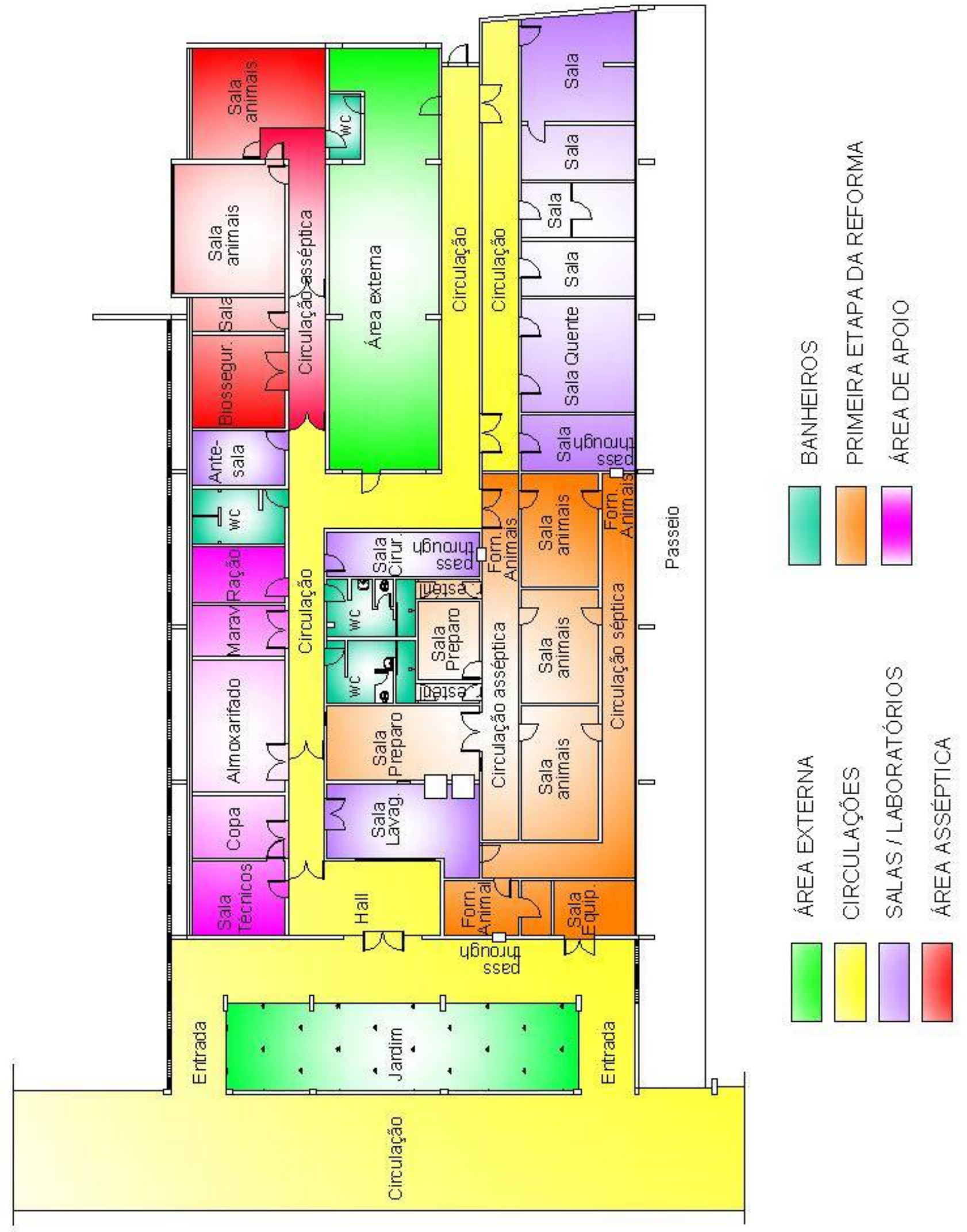

FIGURA 20 - Planta da primeira etapa da reforma 


\section{V.1.1 Adequação das salas de criação}

Nesta reforma, foram demolidas algumas alvenarias das salas, permitindo a união de salas adjacentes, com o objetivo de ampliá-las para atender ao setor de criação com qualidade sanitária controlada.

Resumidamente:

- as portas nas áreas das Salas de Animais foram substituídas por portas com visor e revestimento adequado, para facilitar a manutenção e limpeza;

- foram instalados visores nas alvenarias para comunicação visual entre as áreas;

- os caixilhos com ventilação foram substituídos por caixilhos fixos, com diminuição do vão da alvenaria na área da circulação para evitar violação;

- o piso em granilite foi restaurado e polido devido ao desgaste pelo uso, com aplicação de resina impermeabilizante;

- o forro em gesso foi substituído por forro em PVC; para facilitar a higienização

- foi feita pintura epóxi nas alvenarias das salas de animais para facilitar a limpeza e higienização das áreas;

- foi instalada tubulação em PVC na parte superior das alvenarias para futura instalação da tubulação de exaustão nas Salas de Animais;

- as luminárias existentes foram substituídas por luminárias vedadas; facilitando a higienização;

- um dos três tanques existentes foi demolido e substituiu-se o revestimento dos outros dois;

- criação de uma Sala de Apoio na área asséptica para estocar os principais insumos utilizados diariamente;

- execução de passagem nos banheiros masculino e feminino para troca de roupa estéril;

- abertura de vãos nas alvenarias para instalação de pass through para troca de materiais entre as áreas controladas e convencionais; 
- instalação de tomadas para viabilizar o uso de diferentes equipamentos para acomodar animais, limpar materiais, trocar o ar, etc.

\section{V.1.2 Instalação de barreiras sanitárias}

Foi criado um segundo corredor para as Salas de Criação, o que possibilitou dividi-los em asséptico (FIG.21) e séptico (FIG. 22), evitando a circulação cruzada entre materiais sujos e limpos. Os encontros das alvenarias com o piso, com o teto e com as próprias alvenarias foram executados com cantos arredondados, para facilitar a limpeza e a desinfecção. Todas as alvenarias foram revestidas e pintadas posteriormente com tinta epóxi, por apresentar grande resistência, ser lavável e de fácil desinfecção.

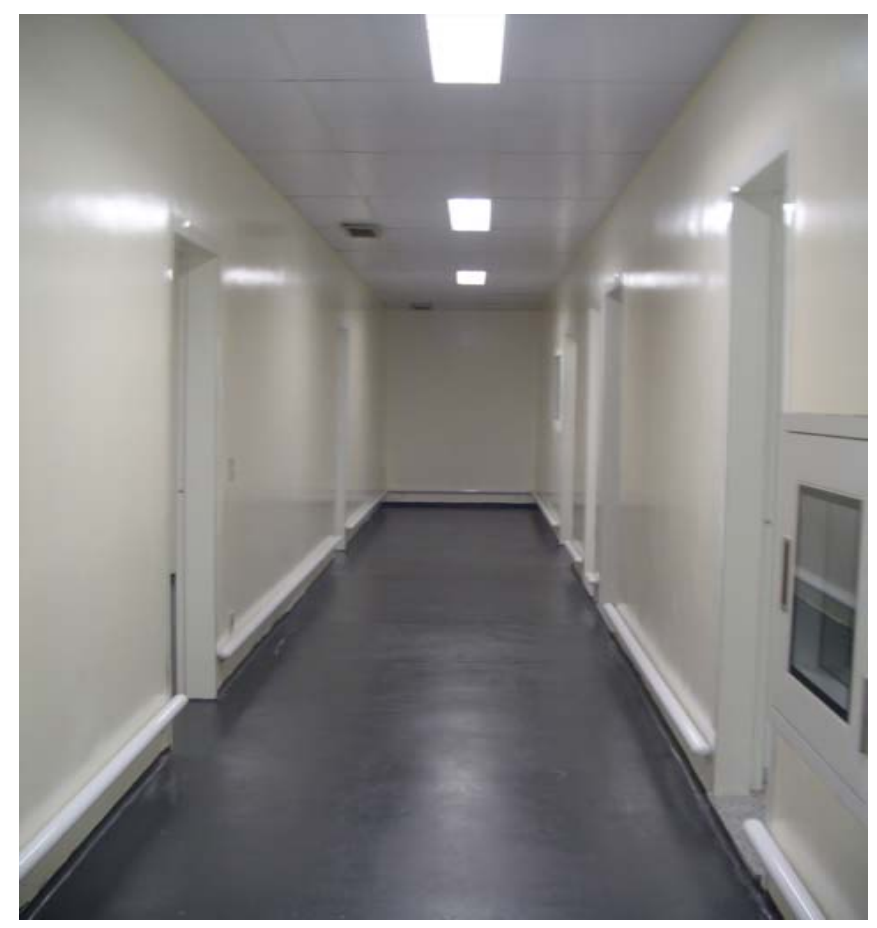

FIGURA 21 - Corredor asséptico após a primeira etapa da reforma. 


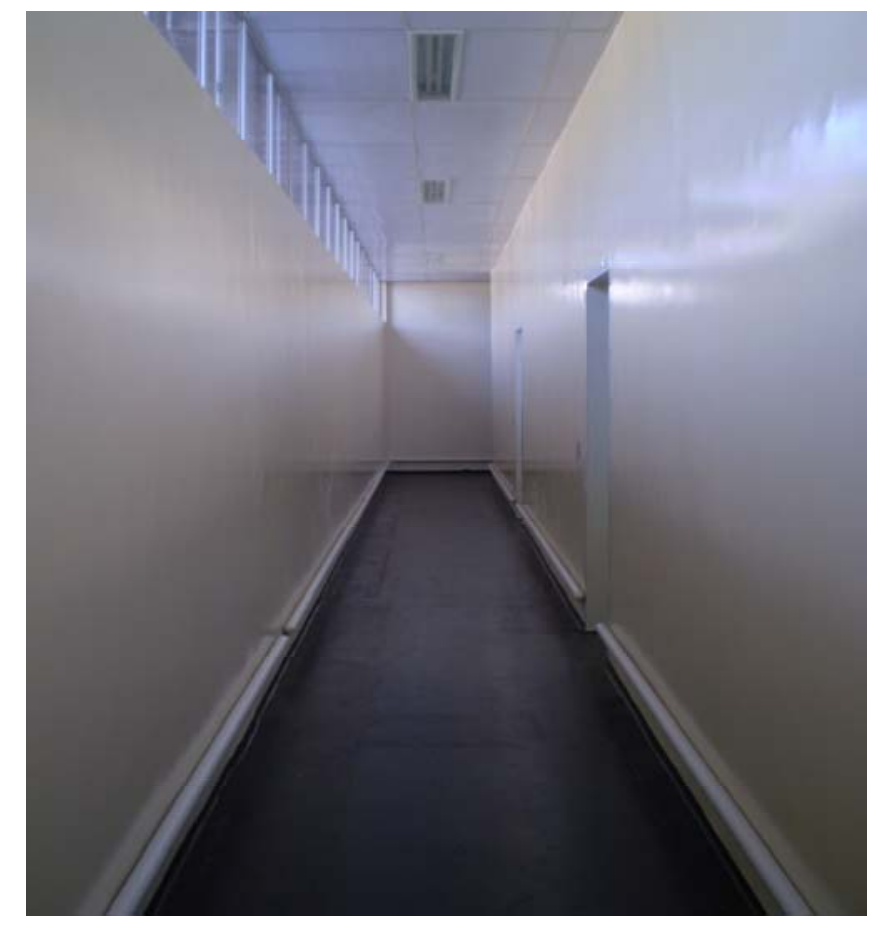

FIGURA 22 - Corredor séptico após a primeira etapa da reforma.

Foi aberto um vão na alvenaria e instalada uma porta tipo balcão (FIG.23), ligando a circulação séptica à área de lavagem, para a passagem do material recolhido das salas dos animais por ocasião da higienização semanal.

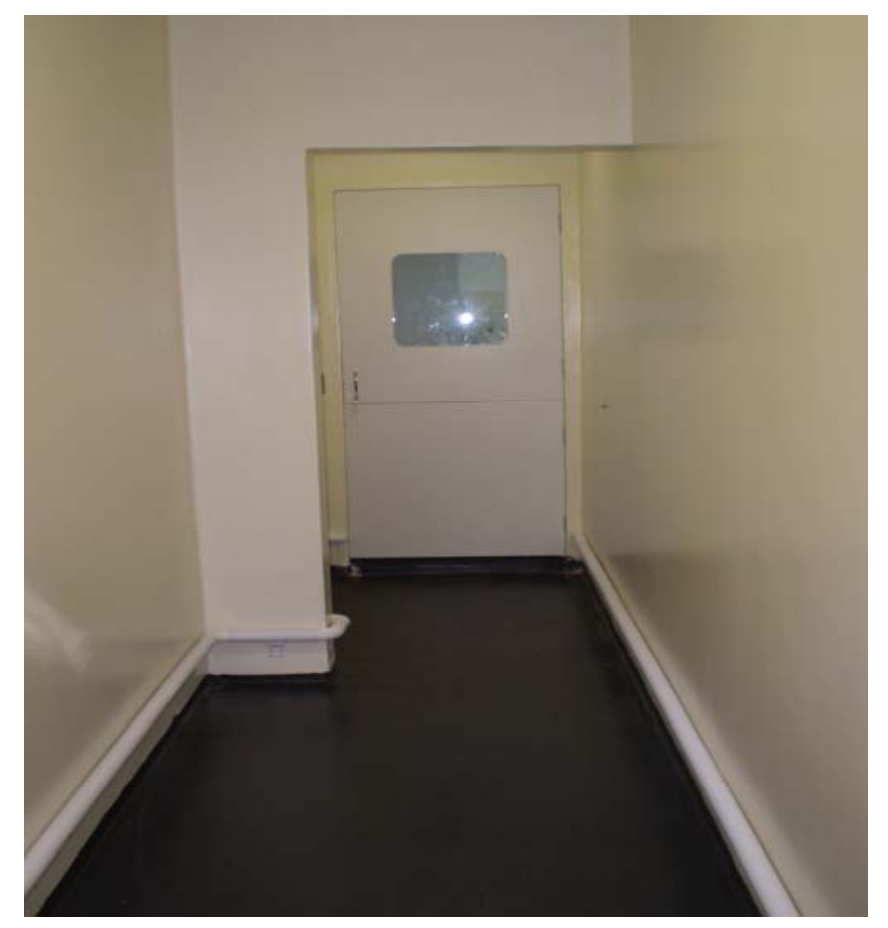

FIGURA 23 - Porta tipo balcão. 
Foram instalados três pass through. São câmaras de passagem de materiais ou animais entre dois ambientes, com a finalidade de minimizar a contaminação cruzada. Foi instalado um entre a Circulação asséptica e a Sala de Cirurgia (FIG.24), outro entre a Circulação Séptica e o Laboratório (FIG.25) e outro localizado entre a Sala de Fornecimento de Animais e a circulação principal de entrada do prédio (FIG.26).

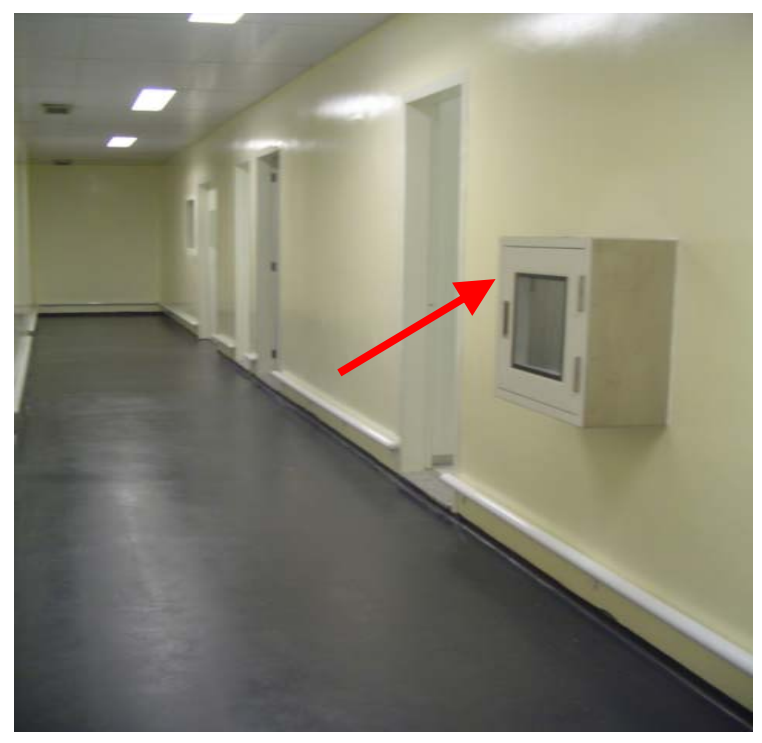

FIGURA 24 - Pass through instalado na circulação asséptica.

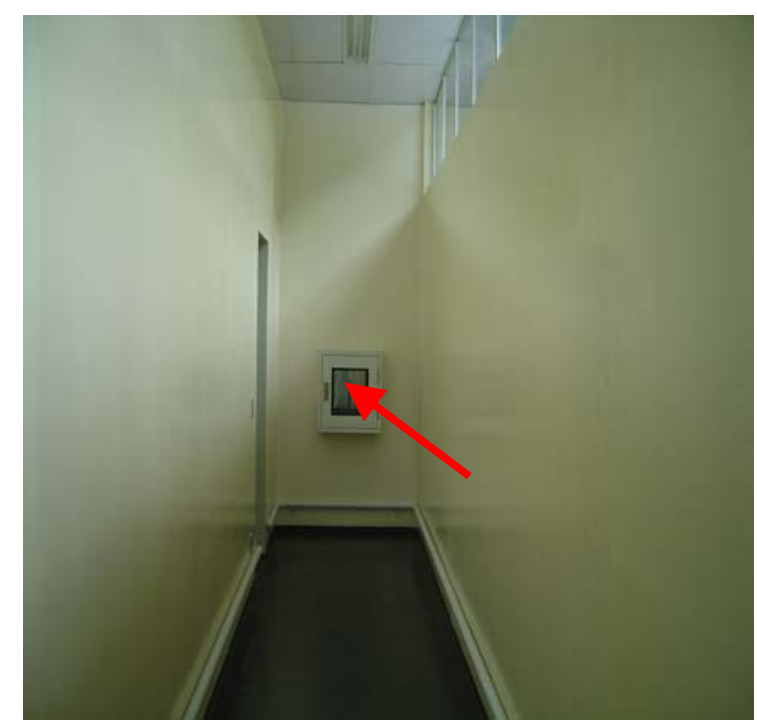

FIGURA 25 - Pass through instalado na circulação séptica.

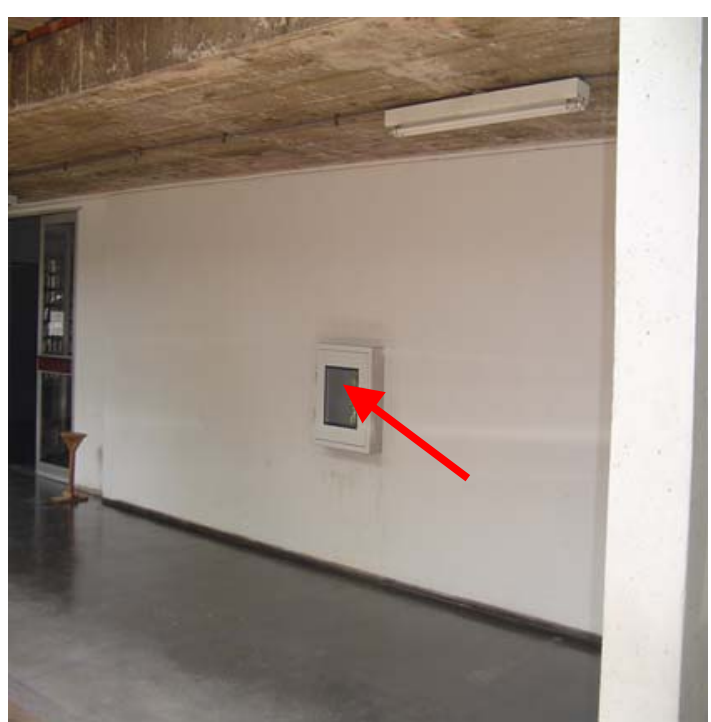

FIGURA 26 - Pass through instalado para atender fornecimento de animais. 
$\mathrm{Na}$ área dos banheiros feminino (FIG.27) e masculino (FIG.28), após o local dos chuveiros, foi criada uma passagem, para acesso à área de criação, somente para pessoas autorizadas a trabalhar nesse ambiente. Essa passagem será destinada a paramentação. Foi instalado na alvenaria de cada passagem um armário, faceando a parede, totalmente revestido em laminado melamínico para facilitar a limpeza, onde ficará o kit com a roupa estéril.

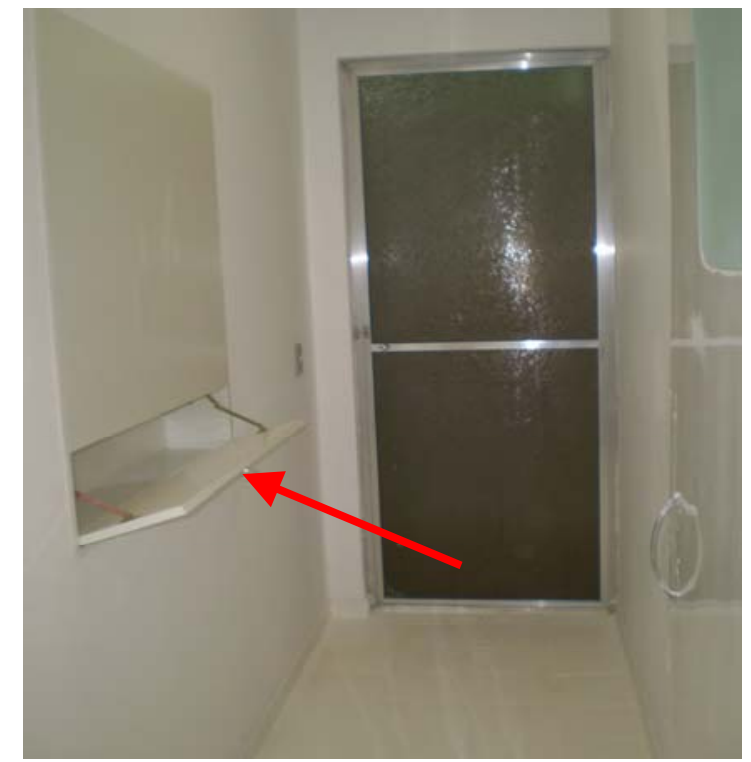

FIGURA 27 - Passagem do banheiro feminino e armário.

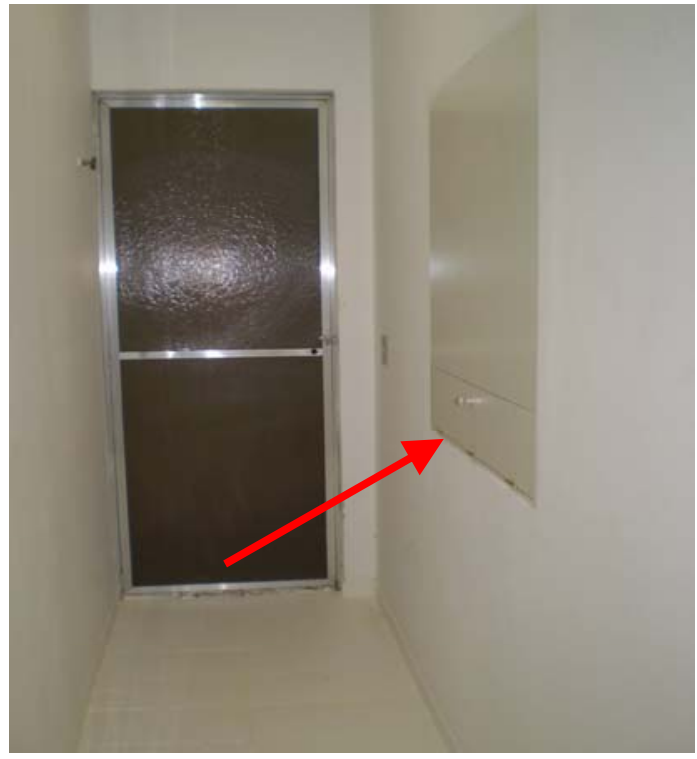

FIGURA 28 - Passagem banheiro masculino e armário.

A Sala de Preparo de Material, adjacente à sala de lavagem, é a área onde foi adequada para acomodar os materiais autoclavados, que serão utilizados para a troca e alimentação dos animais da área de criação. Na alvenaria que divide a Sala de Lavagem e a Sala de Preparo foram instaladas duas autoclaves de barreira (FIG.29), utilizadas na esterilização materiais usados nessa área, como mini-isoladores, tampas, bebedouros, ração, maravalha e outros. 


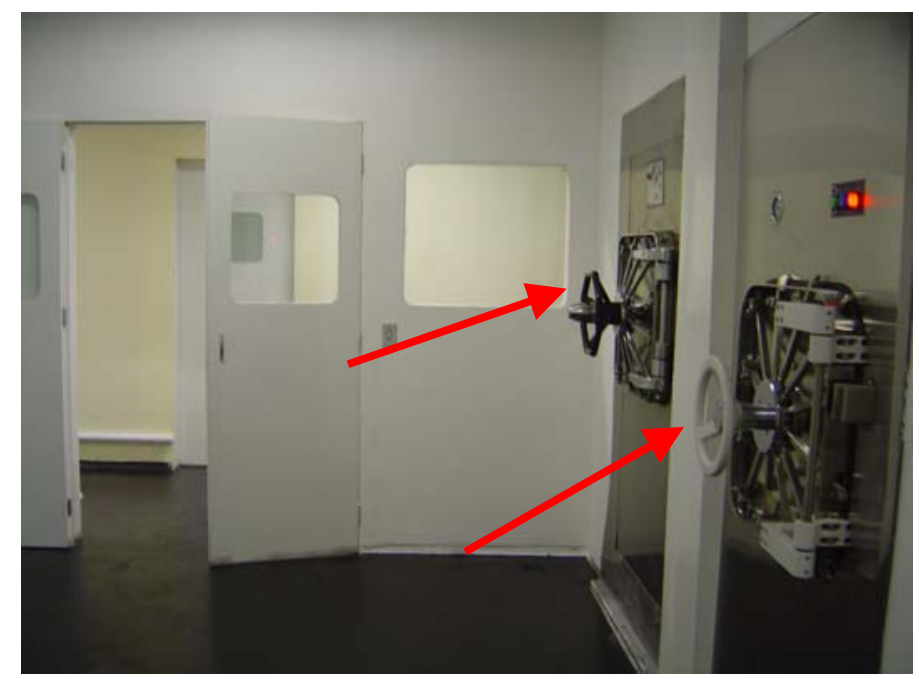

FIGURA 29 - Autoclaves de barreira.

\section{V.1.3 Utilização de materiais e instalação de equipamentos mais adequados}

Nas áreas das Salas de Criação e circulação séptica e asséptica, foram instaladas luminárias vedadas de embutir no forro (FIG.30), indicadas para sala limpa, sem saliências e degraus no forro, evitando o acúmulo de poeira.

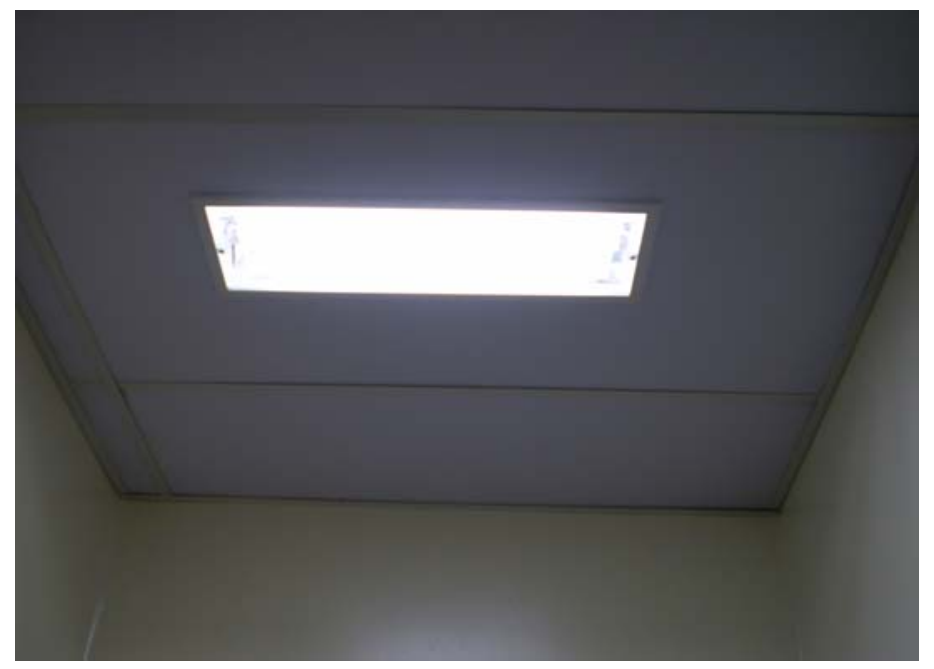

FIGURA 30 - Luminária de embutir vedada.

Foram removidos os caixilhos existentes no corredor séptico, executado fechamento na alvenaria (FIG.31) para diminuir o vão e instalaram-se vidros fixos, 
com aplicação de silicone em todo o perímetro do vão, apenas para iluminação devido à extensão do corredor (FIG.32).

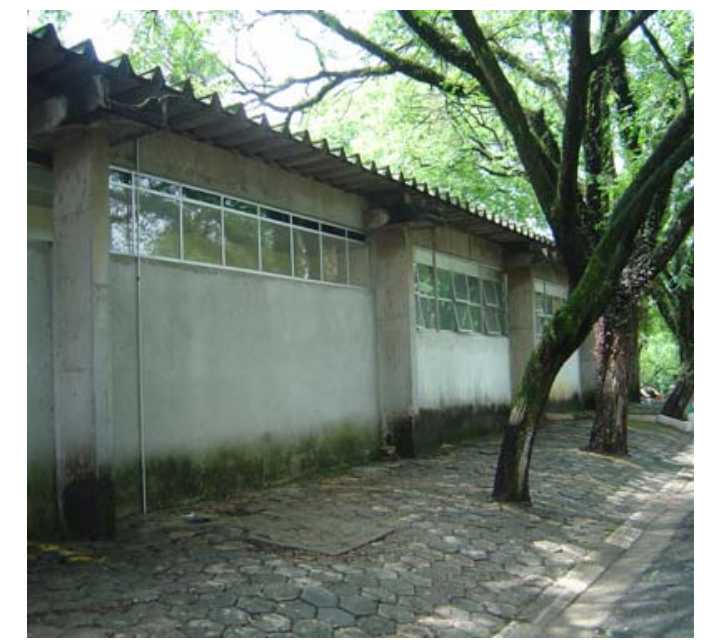

FIGURA 31 - Fechamento das alvenarias. FIGURA 32 - Instalação de vidros fixos.

Em toda a área da circulação asséptica e séptica, foram instalados protetores, em tubo galvanizado (FIG.33) com pintura eletrostática, na parte inferior das alvenarias, para evitar danos decorrentes de batida dos carrinhos ou outros equipamentos. Na parte inferior da porta dupla, destinada apenas a entrada de materiais, que dá acesso ao corredor séptico, foram instalados protetores (FIG.34) para evitar a entrada de insetos e poeira.

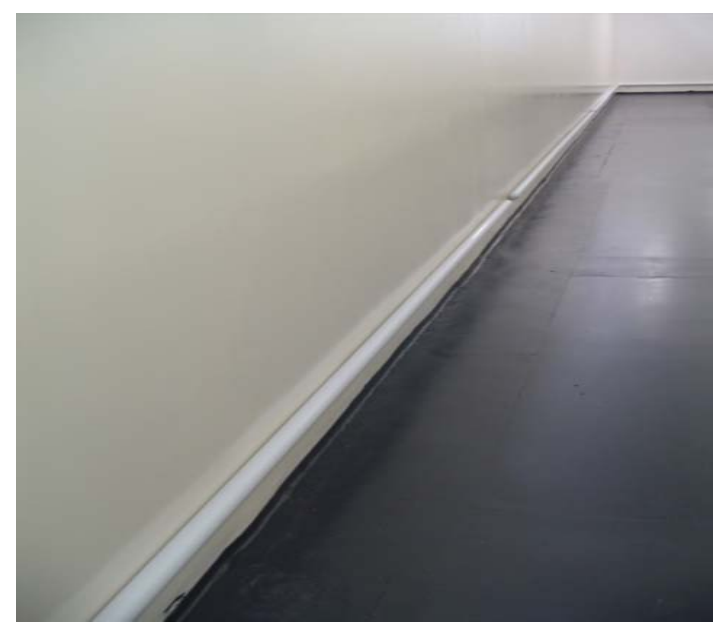

FIGURA 33 - Protetores nas alvenarias. FIGURA 34 - Protetores contra insetos.

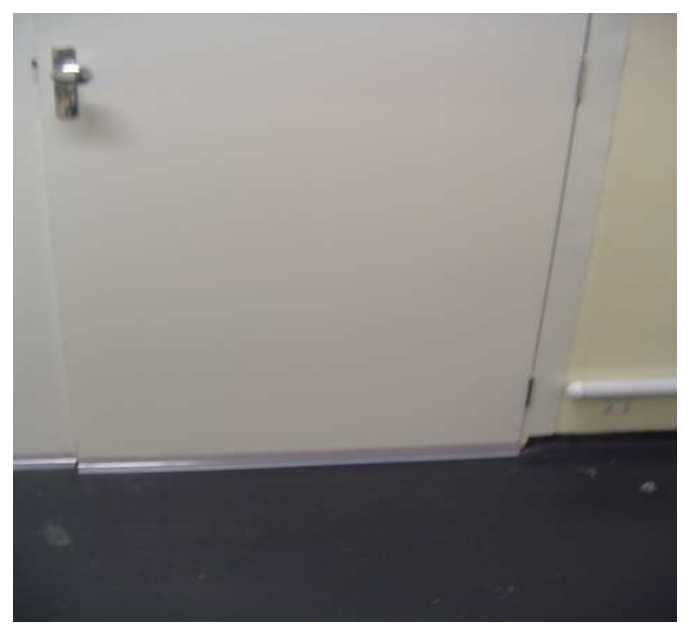


Para acionamento das lâmpadas das Salas de Animais, na área de criação, foi instalado um Timer Digital Profissional (FIG.35), com variação de tempo de $12 \times 12$ horas, alternando períodos claros (C) e escuros (E), programado para as 6:00 e 18:00 horas. A instalação desse aparelho é importante, pois a luz visível estimula fotorreceptores, controla a fotoperiodicidade, regulando os ritmos circadianos, ciclos reprodutivos, atividade locomotora, consumo de água e alimentos, temperatura corpórea e outros elementos. Esse Timer foi instalado na circulação (FIG. 36), fora da área de criação.

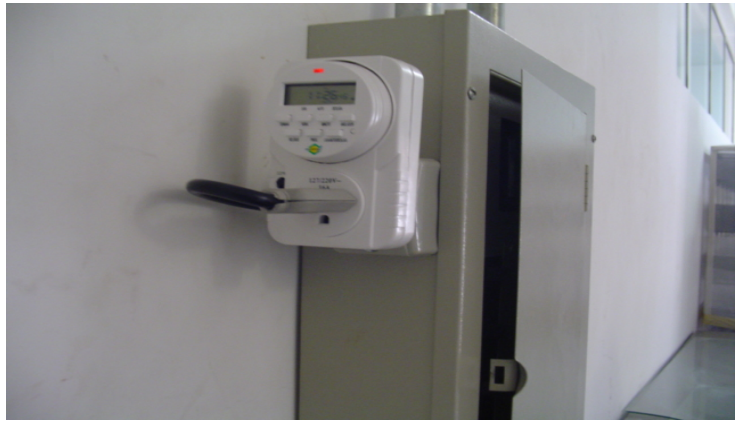

FIGURA 35 - Instalação de timer.

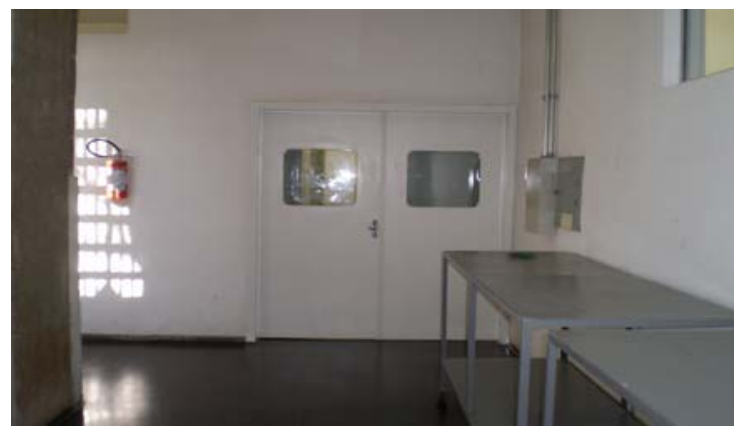

FIGURA 36 - Circulação.

As portas em madeira foram substituídas por portas revestidas em laminado melamínico (Fórmica) e visor com vidro duplo (FIG.37), faceando o nível da porta. Houve grande preocupação quanto aos materiais a serem instalados e como seriam executados, para que não deixassem frestas nem saliências.

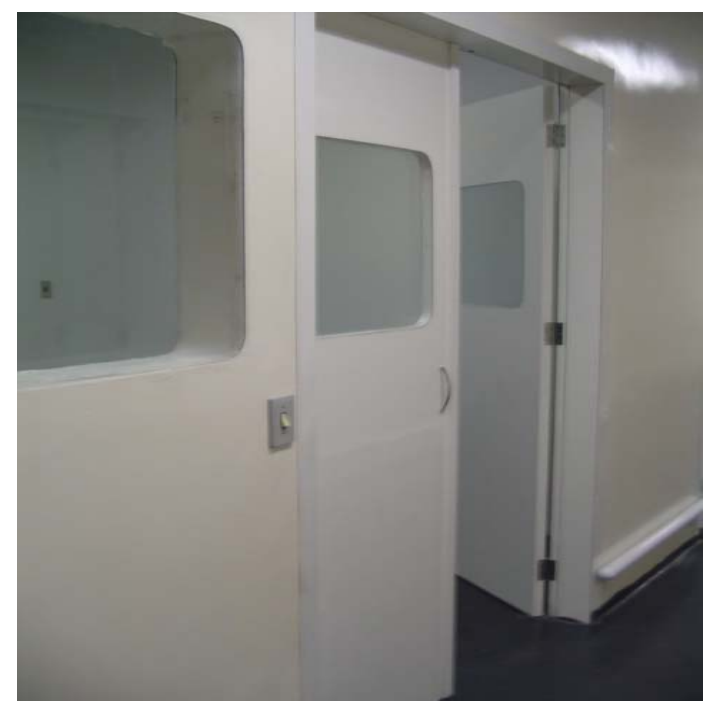

FIGURA 37 - Portas com visores. 
Nas salas de criação, foram instalados forros em placas de PVC, apoiados em estrutura de alumínio. Para perfeita vedação das placas foi aplicado silicone entre todas as placas e a estrutura de alumínio, para prevenir a entrada de poeira e garantir a estanqueidade. As placas de PVC são fáceis de limpar e higienizar, têm boa durabilidade, além de serem resistentes a ação de fungos, bactérias e à maioria dos agentes químicos.

No piso existente em granilite, foi aplicada resina acrílica para impermeabilizar e fechar os poros, facilitando a limpeza e a desinfecção da área.

A pintura em toda a área das salas de criação foi executada com tinta epóxi, devido à alta resistência, facilidade de higienização e limpeza.

Os tanques (FIG.38) foram revestidos em azulejo para facilitar a limpeza e a higienização do ambiente.

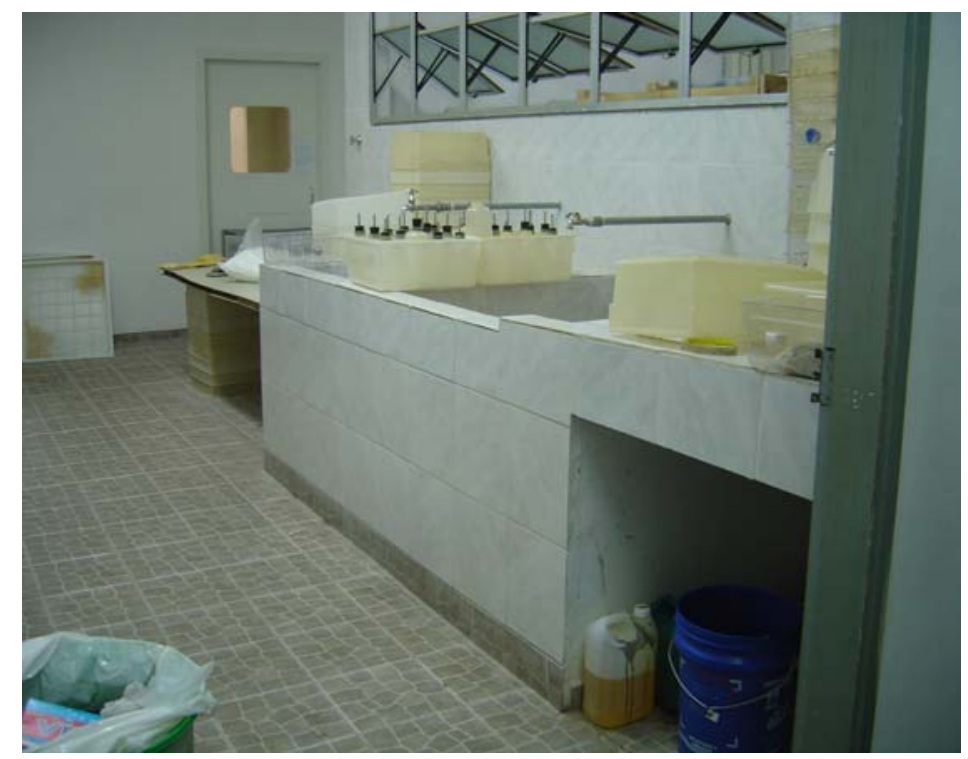

FIGURA 38 - Revestimento de azulejo nos tanques.

A canaleta e grelha (FIG.39) existentes na entrada da sala de lavagem foram removidas, feitas as instalações hidráulicas necessárias. A antiga grelha foi substituída por uma grelha para ralo tipo abre/fecha, para evitar a entrada de insetos. 


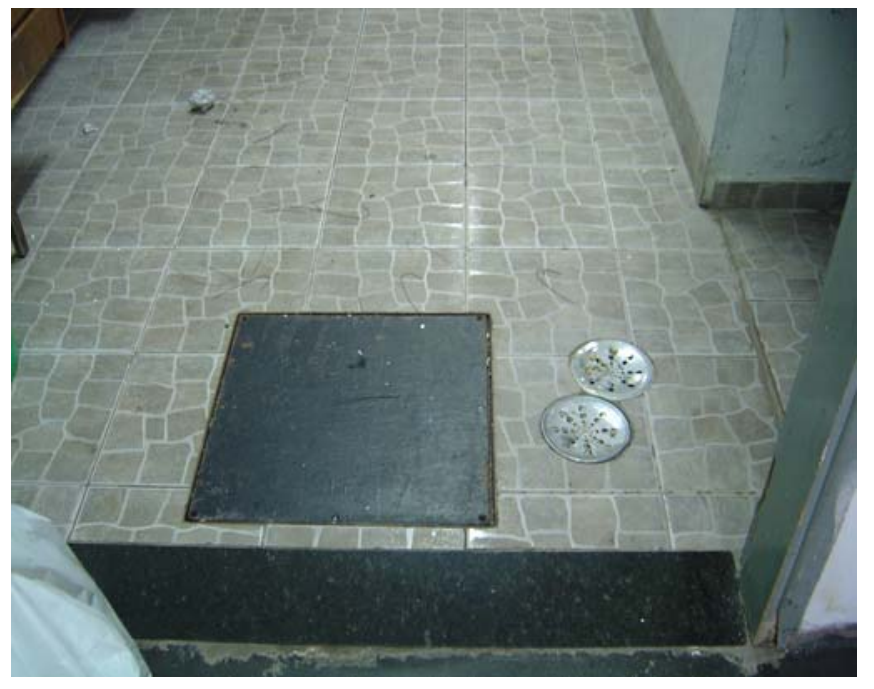

FIGURA 39 - Fechamento de canaleta no piso.

Foram instalados dois visores com vidro duplo (FIG.40), faceando a alvenaria, para facilitar a limpeza e não deixar acumular poeira. A finalidade desses visores é a comunicação visual entre as pessoas, sem necessidade de abertura de portas, pois sendo uma área restrita a alguns funcionários é importante esse tipo de comunicação. Os visores permitem ainda que os visitantes possam conhecer e acompanhar a rotina do Biotério sem, contudo, ter acesso direto à área restrita. Também foi executado rodapé arredondado, do tipo hospitalar, para facilitar os procedimentos de higienização e limpeza.

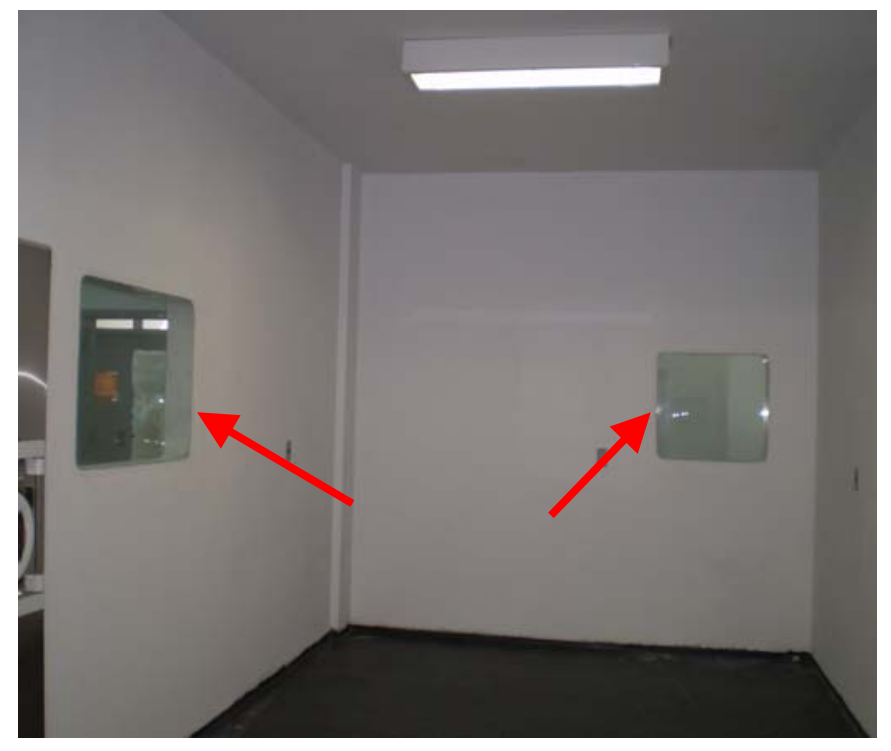

FIGURA 40 - Visores com vidro duplo. 
A entrada para a sala do equipamento de ar condicionado central (FIG.41) foi isolada da área interna do prédio, facilitando a manutenção.

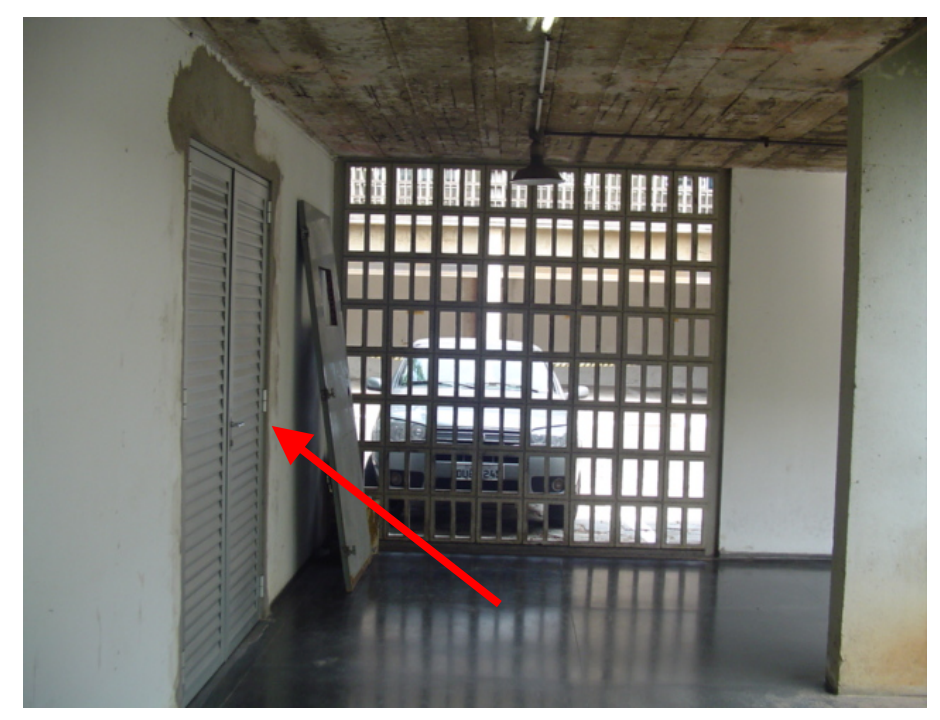

FIGURA 41 - Entrada para a sala de equipamento.

As aberturas existentes na parte inferior das alvenarias foram fechadas com uma chapa de aço inoxidável, para evitar a entrada de insetos no prédio e as grelhas dos ralos foram substituídas por tampas cegas em aço inoxidável. Nos locais das Circulações Asséptica, Séptica e nas Salas de Criação de Animais não existe ralo no piso para evitar contaminação e entrada de insetos.

\section{V.1.4 Instalação de novo sistema de ventilação}

A movimentação do ar em salas de animais tem fundamental importância na manutenção de condições ambientais adequadas ao controle sanitário e à vida das espécies confinadas (TEIXEIRA, 1995). Entende-se por ventilação o processo de retirar ou fornecer ar, condicionado ou não, por meios naturais ou mecânicos, de/ou para um recinto fechado, com a finalidade de retirar poluentes ou manter condições de conforto para os indivíduos (MACINTYRE, 1990 apud TEIXEIRA, 1995).

A ciência da ventilação divide-se em dois grandes princípios: a Ventilação Local Exaustora (VLE) e a Ventilação Geral Diluidora (VGD). No primeiro 
princípio inclui-se o processo de exaustão efetuado diretamente sobre tanques e reatores, nos quais esteja sendo processada uma determinada reação química ou físico-química que libere poluentes tóxicos ((MESQUITA et al. 1988; MACINTYRE, 1990; CETESB, 1992) apud TEIXEIRA, 1995).

Em ambientes de uso humano utiliza-se o princípio da Ventilação Geral Diluidora (VGD). Este sistema tem por princípio a introdução de uma massa de ar limpo que, ao misturar-se ao ar do ambiente, promove a diluição da concentração de poluentes e sua posterior remoção ((MESQUITA et al., 1988; MACINTYRE, 1990; CETESB, 1992) apud BARBOSA, 1999).

Biotérios equipados com dispositivos para VGD apresentam ambientes de melhor qualidade do que biotérios desprovidos de qualquer equipamento de ventilação. Todavia, o princípio da VGD tem-se demonstrado de uso limitado para salas de animais, pois não possibilita que o ar do microambiente seja renovado diretamente (CARISSIMI, 1998). É justamente no interior das gaiolas onde ocorre a geração de gases, dejetos, partículas provenientes da movimentação dos animais e calor gerado pelo metabolismo (BARBOSA, 1999).

Cabe lembrar, que a alergia relacionada a animais, atualmente, é um importante risco que enfrentam os trabalhadores de biotérios ((NEWMANTAYLOR \& GORDON, 1993) apud Costa et al., 2008). O contato com os animais ocorre durante os processos de limpeza, alimentação, procedimentos invasivos e transporte entre instalações. Esses contatos geram exposições à caspa animal, ao pêlo, à urina, à saliva, aos tecidos e ao soro ((HARRIES \& CROMWELL, 1982) apud Costa et al., 2008). As respostas alérgicas variam de brandas, como coriza, espirro, irritação ocular, erupção na pele, entre outras, a graves, como dificuldade respiratória ((SILVA, 2004) apud Costa et al., 2008).

No caso do Biotério do IPEN foi instalado um sistema de ar condicionado de conforto, que atende a Circulação Asséptica e as Salas dos Animais. As grelhas por onde é feito o insuflamento do ar estão faceando o forro (FIG.42) e as alvenarias (FIG.43), evitando o acúmulo de poeira nos ambientes. 


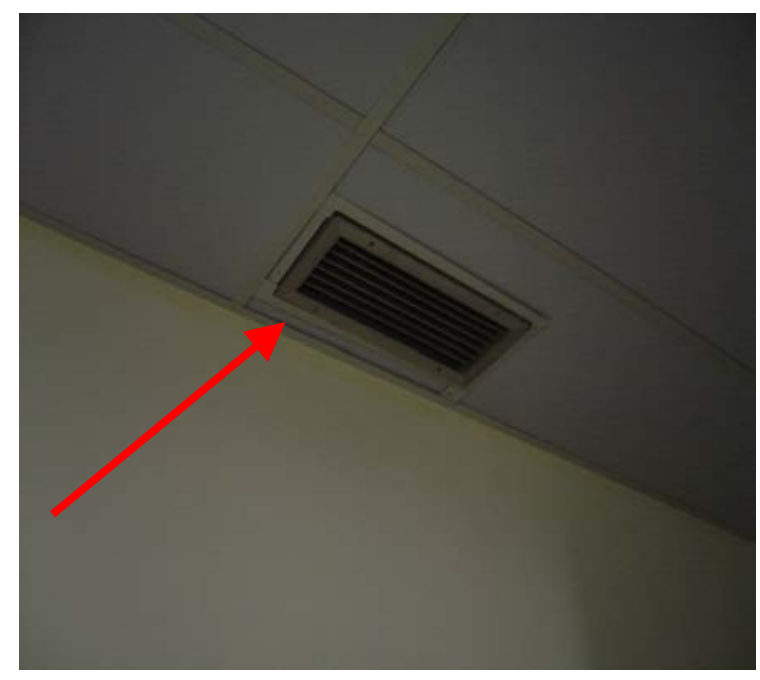

FIGURA 42 - Grelha no forro.

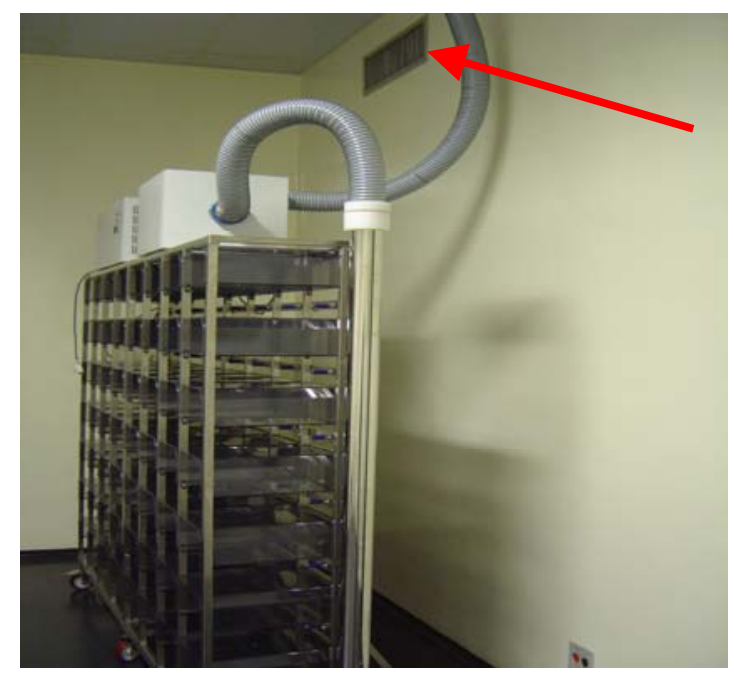

FIGURA 43 - Grelha na alvenaria.

As prateleiras em concreto foram substituídas por estantes e racks ventilados que possuem o sistema de Ventilação Microambiental (VMA). Nesse sistema (VMA) a climatização ocorre particularmente em cada gaiola de criação diminuindo possíveis contaminações.

Os animais são mantidos dentro de mini-isoladores (FIG.44), projetados para manutenção de animais de laboratório como camundongos, hamsters ou ratos. Possuem filtro lavável e de fácil substituição, travas de segurança, aramado interno reforçado em aço inoxidável e hastes internas que protegem contra deformações e impactos (ALESCO IND. E COM.).

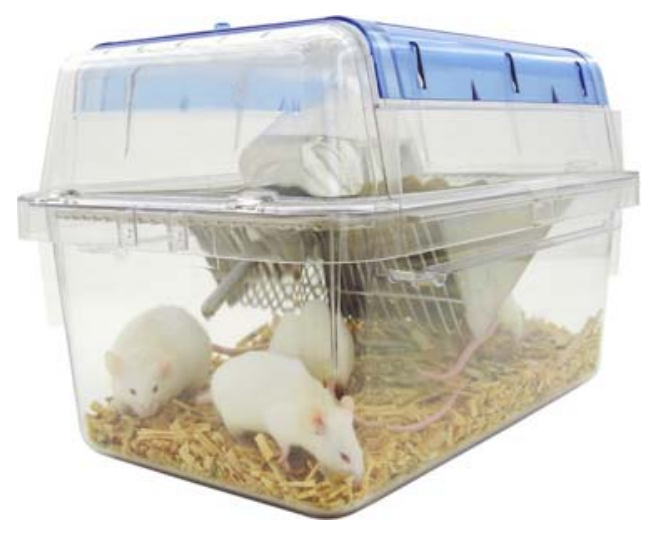

FIGURA 44 - Mini-isolador (ALESCO IND. E COM.). 
Esses mini-isoladores são dispostos em racks ventilados ou estantes ventiladas. Cada mini-isolador contém uma válvula que permite a ativação automática do fluxo de insuflamento após encaixe do mini-isolador, apresentando fluxo de ar contínuo, porém não direto e em baixa velocidade, através de dissipador, permitindo o arraste homogêneo da amônia e $\mathrm{CO}_{2}$, favorecendo o bem estar animal, dutos de exaustão retirando a amônia e $\mathrm{CO}_{2}$, diretamente para fora da sala.

Os racks ventilados (FIG.45) instalados nas salas dos animais são equipamentos que proporcionam redução significativa de custo em relação ao sistema de condicionamento e circulação de ar, pois são providos de sistemas de ar independentes com dupla filtragem na entrada e saída, com filtro lavável, préfiltro plissado e filtro HEPA.

A utilização desses racks é importante, pois reduz o risco de infecções que podem interferir nos resultados experimentais, melhora a ocupação da área física pois têm capacidade de alojar grande número de animais em pouco espaço e também confere às salas conforto ambiental, removendo cheiros e contaminantes. Nas estantes (FIG.46), existe a possibilidade de manter diferentes espécies em um único equipamento (ALESCO IND. E COM.).

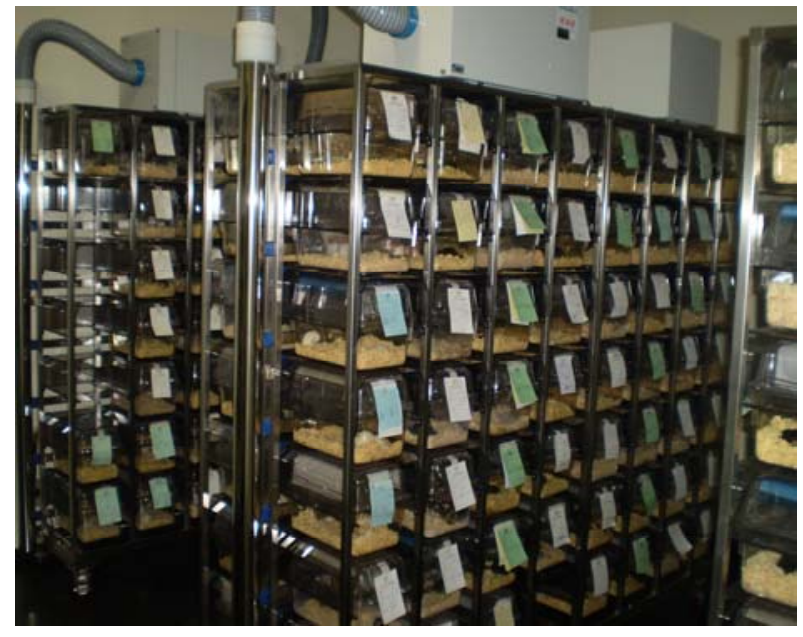

FIGURA 45 - Racks ventilados no Biotério do IPEN.

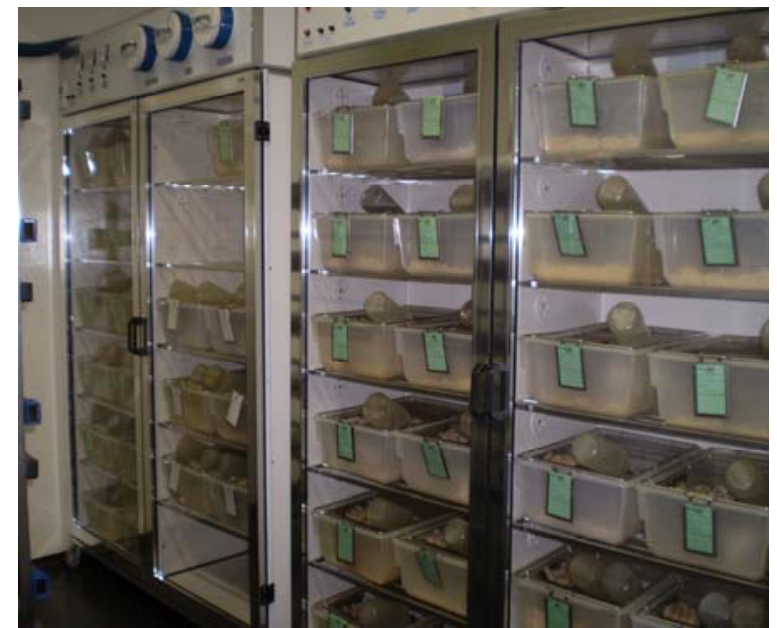

FIGURA 46 - Estantes ventiladas no Biotério do IPEN. 
V.2 Projeto da segunda etapa da adequação e reforma das instalações do Biotério do IPEN/CNEN-SP

Planta com as modificações a serem implantadas na segunda etapa da reforma do Biotério (FIG.47).

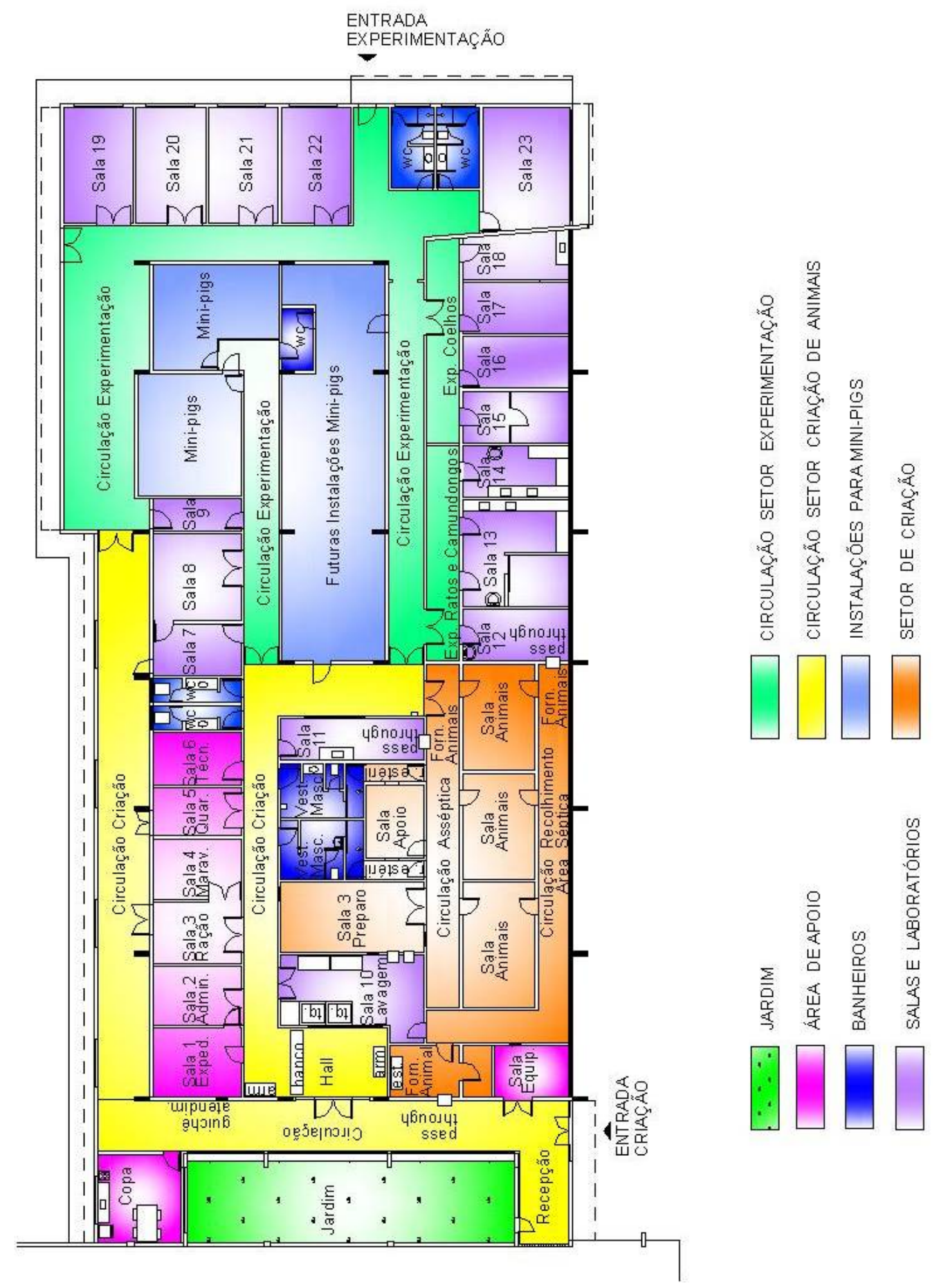

FIGURA 47 - Planta da segunda etapa da reforma 


\section{V.2.1 Modificações a serem introduzidas na segunda etapa da reforma}

O objetivo da segunda etapa da reforma do prédio do biotério do IPEN é adequar às salas de recebimento e armazenamento de materiais e insumos para animais; eliminar o contato direto do interior do prédio com o ambiente externo; segregar as áreas de criação e experimentação; estabelecer fluxos que evitem contaminações; criar barreiras sanitárias adequadas e eficazes para um bom funcionamento da instalação, garantindo a saúde dos animais e das pessoas que trabalham na área.

\section{V.2.1.1 Acesso ao Biotério}

A entrada para a área do Biotério será mudada, de forma a permitir um maior controle de acesso (FIG.48). Para tanto, todas as demais áreas que davam acesso à entrada principal do Biotério serão fechadas de forma a permitir o isolamento do Biotério do restante do prédio (FIG.49). Na porta de vidro, que dá acesso à entrada do Biotério será instalada fechadura com acionamento de entrada restrito, por meio de senha, apenas para pessoas autorizadas. Esse acesso deverá ser controlado ao menor número de pessoas, favorecendo o controle da contaminação dos ambientes e atendendo principalmente os conceitos básicos das normas de biossegurança.

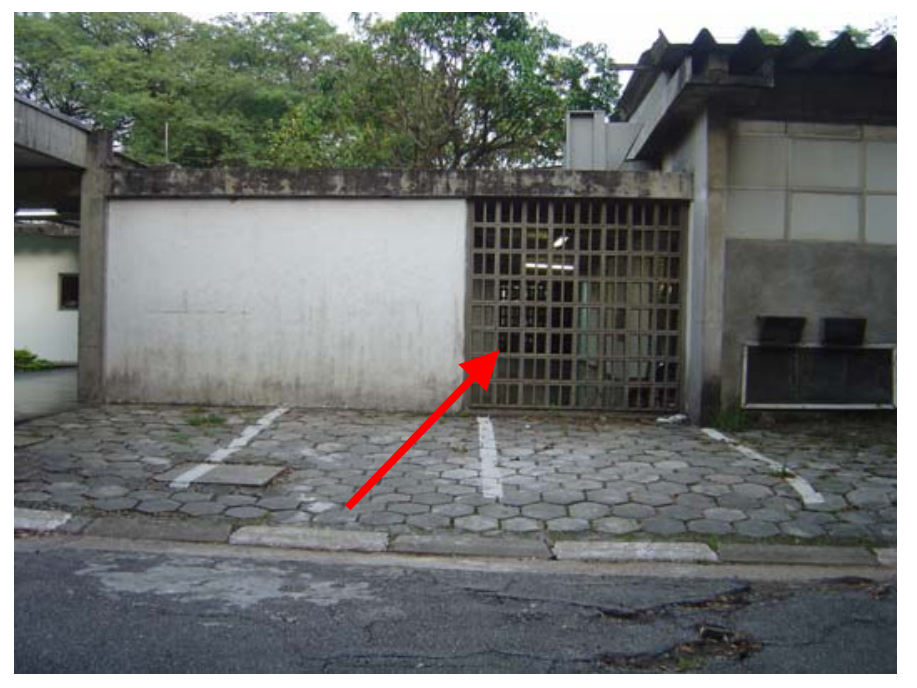

FIGURA 48 - Futura entrada para salas de criação. 


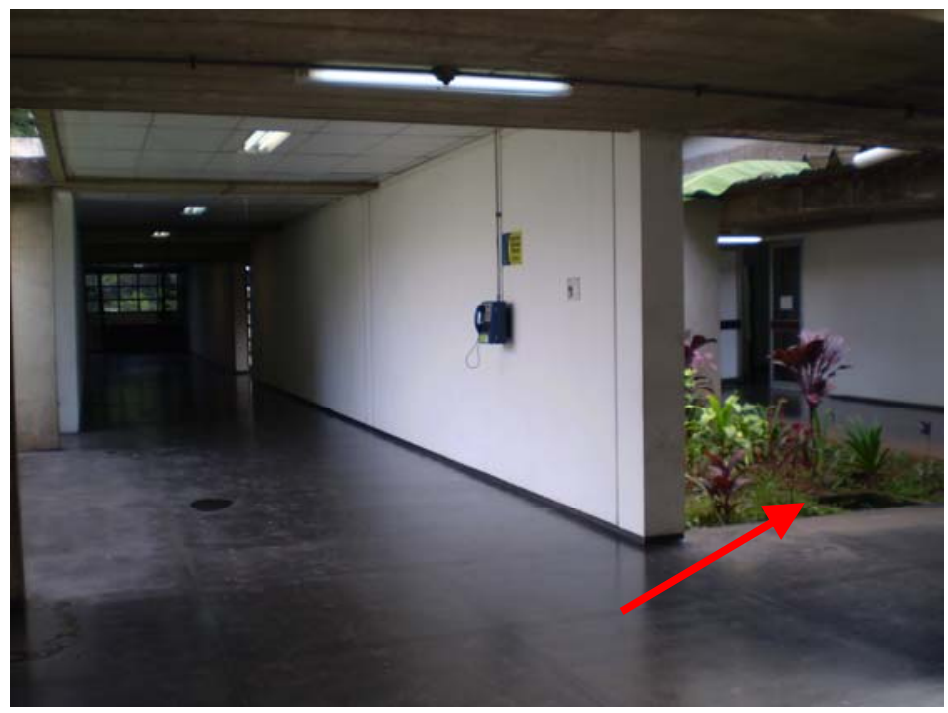

FIGURA 49 - Local a ser fechado com blocos de vidro.

\section{V.2.1.2 Isolamento da área da copa}

A Copa que está localizada numa área adjacente a circulação de entrada, será totalmente isolada da área do Biotério.

\section{V.2.1.3 Isolamento da área do jardim}

Na área do jardim externo (FIG.50) será construída uma mureta e instalado vidro fixo, para que possa ser visto, sem, contudo apresentar risco de contaminação para a área.

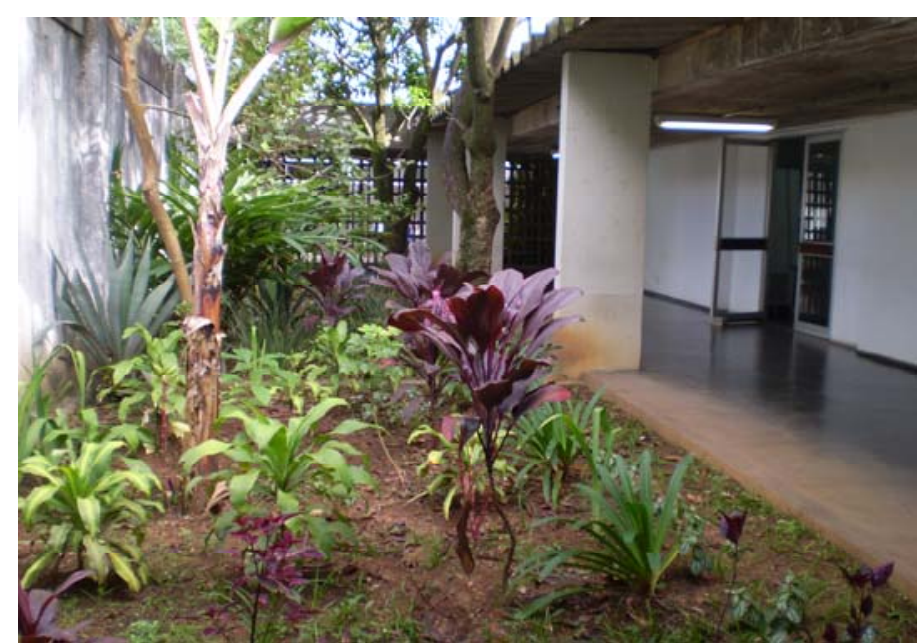

FIGURA 50 - Jardim a ser isolado. 


\section{V.2.1.4 Fluxo e segregação das áreas de Criação e Experimentação}

A nova circulação irá atender a entrada de materiais e serviços necessários ao biotério, e também a entrada para a área de experimentação, com acessos independentes e com o objetivo de isolar a área, facilitar a passagem de materiais e equipamentos sem contra fluxo de animais, pessoas e materiais.

As portas das circulações internas, que ligam o Setor de Criação ao Setor de Experimentação, poderão ser abertas somente pelo Setor de Criação. Essa medida irá reduzir o número de pessoas, manter a segregação das áreas e ajudar no controle da contaminação.

Nas salas de criação de animais, serão instaladas fechaduras de controle de acesso restrito. A instalação dessa fechadura eletrônica limitará ao máximo a entrada de pessoas na área de criação. Nas portas das circulações que ligam a área de experimentação também serão instaladas fechaduras com acionamento de entrada somente de um dos lados. Está sendo proposto o uso de fechaduras da Kaba do Brasil LTDA ou similar, tipo E-PLEX 5000 (KABA). O uso dessa fechadura (FIG.51) é fundamental, principalmente porque criará uma barreira de controle de acesso, atendendo assim os conceitos de biossegurança, bem como, assegurando a saúde dos animais, dos funcionários e a proteção do meio ambiente. Também serão instaladas fechaduras de controle de acesso nas portas de correr dos banheiros masculino e feminino, que separam a área do sanitário da área do chuveiro, para acesso ao local das Salas de Criação de Animais.

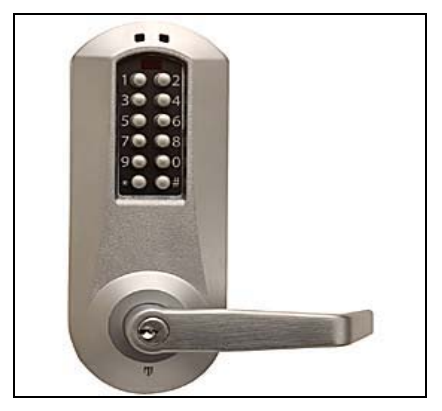

FIGURA 51 - Exemplo de fechadura com controle de acesso rápido. 
A seguir, é apresentada uma planta (FIG.52), com o fluxo a ser implantado na segunda etapa da reforma do Biotério.
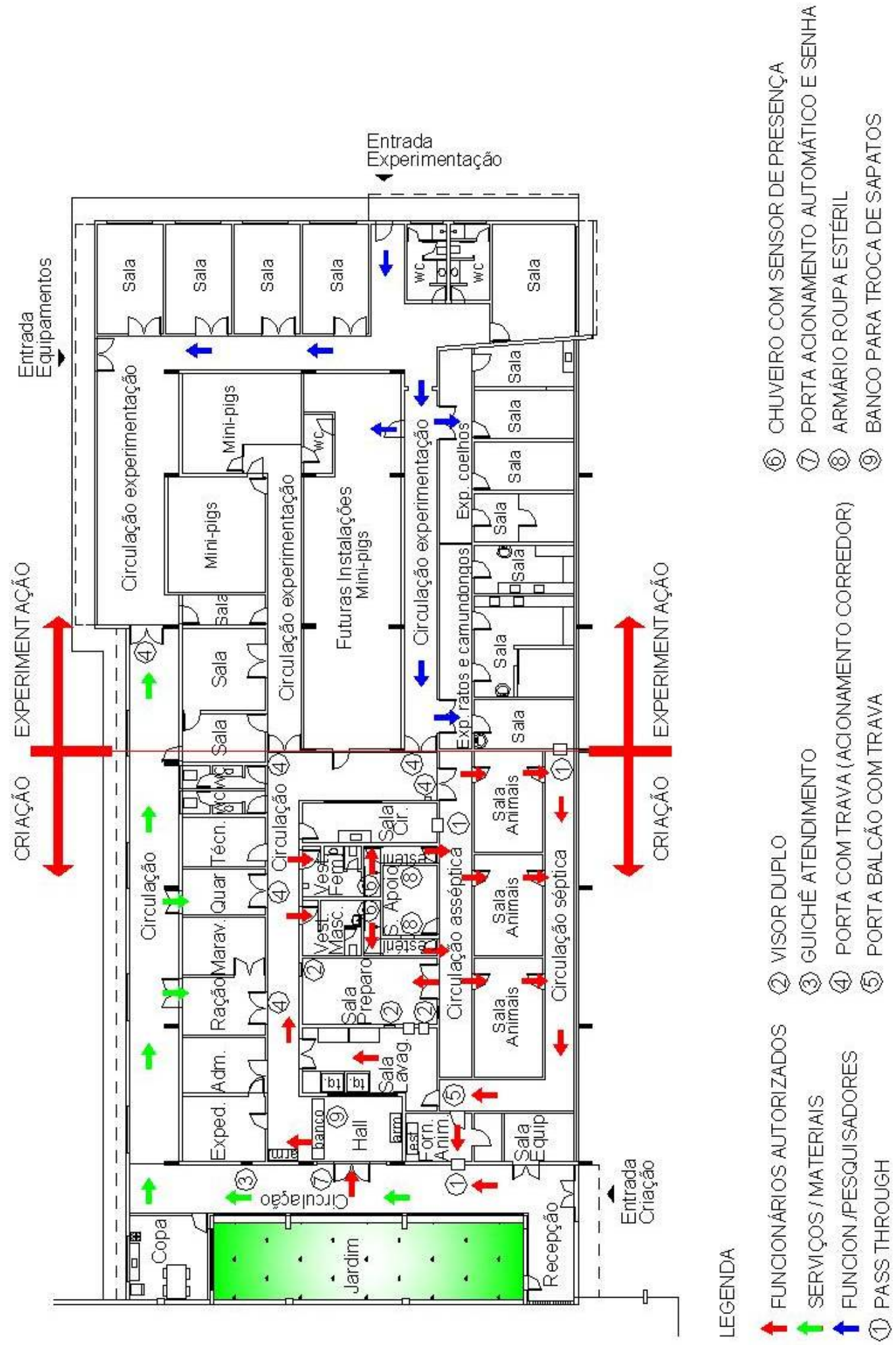

FIGURA 52 - Planta com fluxo a ser implantado 


\section{V.2.1.5 Distribuição dos ambientes no Setor de Criação de Animais}

Na sala 1, designada Expedição, será instalado um guichê de atendimento, com o objetivo de permitir que se atenda o público externo e funcionários, sem que acessem a área interna do biotério.

A sala 2, designada Administração, será a sala do responsável pelo biotério. As paredes serão pintadas com tinta látex, o forro em gesso acartonado e o piso será o existente em granilite com aplicação de resina.

Na sala 3, designada Ração, será fechada a porta que liga ao corredor interno do biotério. A porta permanecerá trancada e será instalada fechadura com trava ou senha no lado do corredor, permitindo o acionamento de entrada somente de um dos lados. Essa medida, a ser tomada, tem como objetivo evitar a passagem de funcionários para a área interna do biotério. Nessa sala, também está sendo prevista a instalação de uma porta dupla que dá acesso à nova circulação, com o objetivo de receber os materiais, com entrada independente, sem que tenha contato com a área interna do biotério.

A mesma porta de acesso da Circulação Interna para a Sala de Ração dá acesso à sala 4, designada Maravalha (camas). Nessa área, não pode haver umidade e nem contato da maravalha diretamente com o chão. Não serão instaladas janelas nessas salas, porém serão climatizadas.

$\mathrm{Na}$ sala 5, designada Quarentena, está sendo proposta a instalação de porta dupla, com entrada independente, para recebimento de animais que vêm de outro local e que obrigatoriamente necessitam ficar isolados, pois podem introduzir infecções e colocar a população animal existente no biotério em risco.

O banheiro existente será dividido em dois para possibilitar a construção de um banheiro feminino e um masculino, para maior conforto dos funcionários e usuários do biotério, sem que haja necessidade de usar o sanitário que dá acesso à área de Criação de Animais. As placas de forro de gesso existentes serão substituídas por placas de gesso acartonado, que devido às suas dimensões, 
proporcionam um menor número de juntas, diminuindo os pontos de possíveis contaminações e acúmulo de poeira.

No local dos caixilhos removidos, será executado o fechamento das alvenarias, garantindo assim o isolamento e possíveis contaminações, das salas com a área externa. No memorial descritivo para a segunda etapa da reforma e adequação do Biotério do IPEN, de acordo com os recursos disponíveis, procurou-se atender às normas de biossegurança, com o intuito de proporcionar melhores condições de trabalho e saúde aos funcionários, bem estar dos animais, preservar o meio ambiente e assegurar bons resultados dos trabalhos de pesquisa.

As alvenarias serão pintadas com tinta látex acrílica, para facilitar a limpeza e a desinfecção. O piso existente em granilite deverá receber resina acrílica para fechar os poros e facilitar a limpeza. Na área da circulação nova, o piso será executado com cantos arredondados no mesmo padrão e acabamento já adotado.

\section{V.2.1.6 Distribuição dos ambientes no Setor de Experimentação de Animais.}

A área designada Experimentação Animal irá atender aos laboratórios e salas, destinados aos experimentos, a serem executados com coelhos, ratos e camundongos. A circulação interna dessas áreas será independente. Também está prevista área para futuras instalações para experimentação com mini-pigs.

Com a ampliação desse local, será possível a segregação das áreas de criação e experimentação, com entrada totalmente independente. Essa separação de áreas deverá contribuir no que diz respeito a possíveis contaminações e assim, evitar prejudicar os resultados dos experimentos. 


\section{V.3 Novos procedimentos a serem instituídos nas instalações do Biotério do IPEN/CNEN-SP}

Com as reformas e adequações em execução no Biotério do IPEN, serão instituídos novos procedimentos no funcionamento dessa área, que irão atender melhor às normas de biossegurança e assegurar o bem-estar dos animais e a saúde dos funcionários.

Estão sendo criadas barreiras sanitárias obrigatórias para limitar o acesso das pessoas, favorecendo a manutenção e também o bem-estar dos animais, adaptando as áreas físicas do prédio para melhorar os fluxos de trabalho. Buscase ainda a segregação da área de criação (FIG.53) e de experimentação (FIG.54), criando circulação independente para entrada de materiais e serviços, circulações unidirecionais na área de criação de animais para eliminar cruzamento de fluxos, eliminação do contato direto com a área externa. Estas ações visam contemplar itens que são fundamentais para o bom funcionamento do biotério como eliminar interferências e contaminações, oferecendo um ambiente mais adequado, evitando riscos, etc.

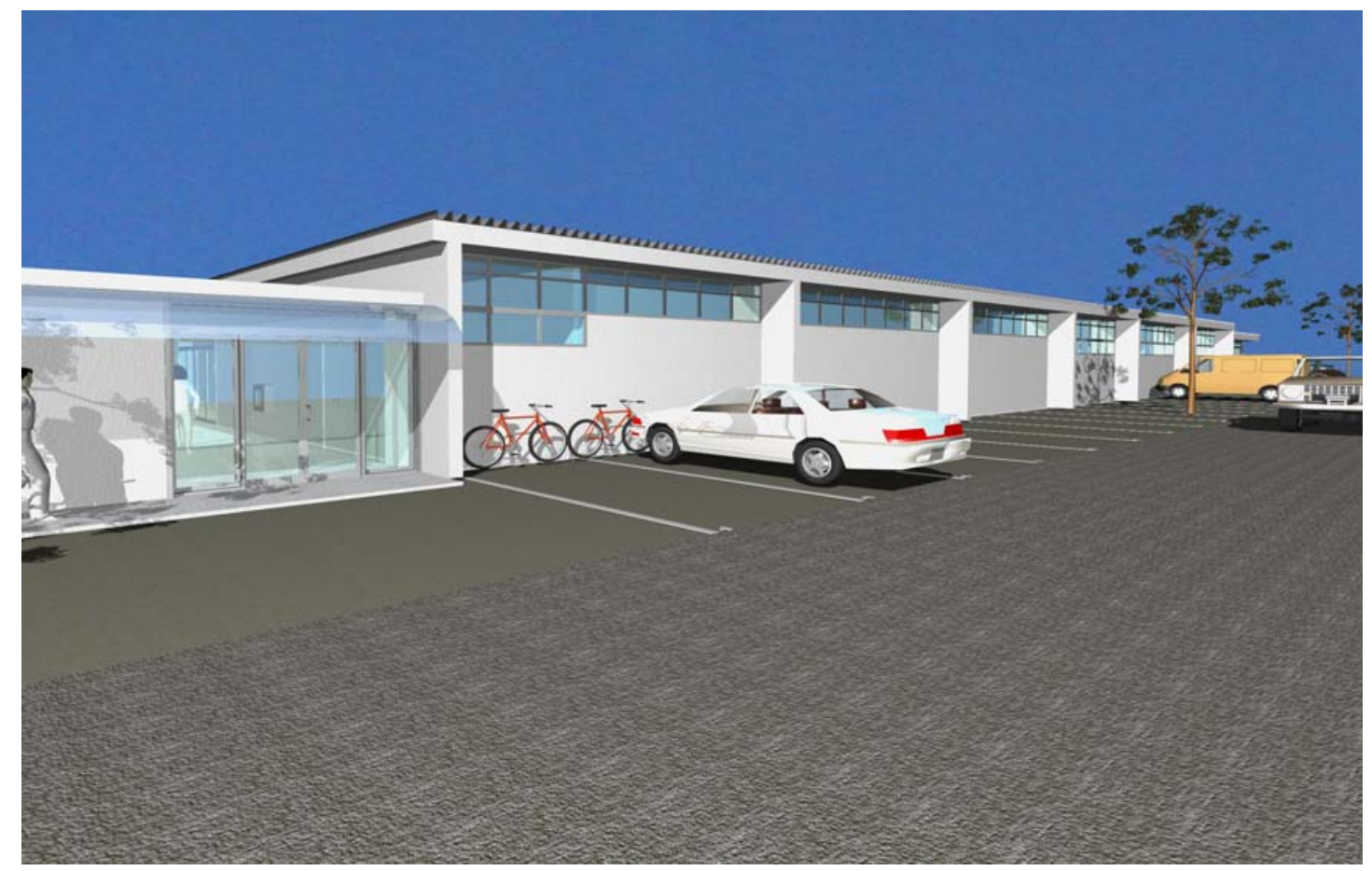

FIGURA 53 - Futura entrada da área de criação. 


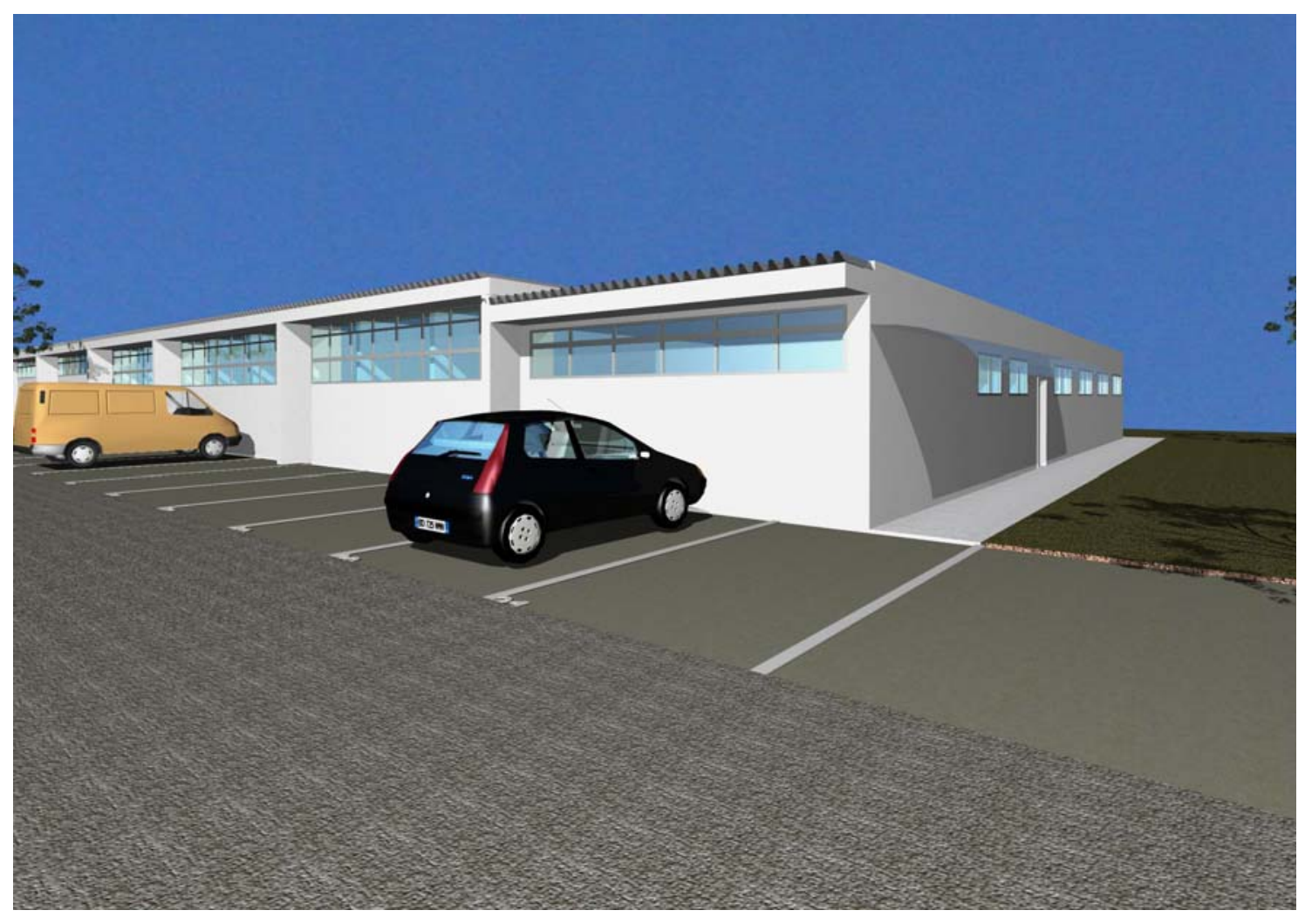

FIGURA 54 - Futura entrada da área de experimentação.

Com o fechamento dos vãos das alvenarias com blocos de vidro, a área do Biotério, ficará totalmente isolada do restante do prédio já existente, impedindo que pessoas de outras áreas circulem nesse ambiente, sem que sejam identificadas.

A instalação das placas de forro em PVC sob a laje existente, na área do corredor de entrada, facilitará a limpeza e a higienização do ambiente, proporcionando melhores condições de trabalho.

O fechamento do jardim com vidro (FIG.55) eliminará o contato direto do Biotério com a área externa, eliminando possíveis contaminações e interferências relacionadas com as condições do tempo, como entrada de poeira, vento, chuva, etc. Contudo, está prevista a instalação de uma porta de acesso com chave, para manutenção das plantas. 


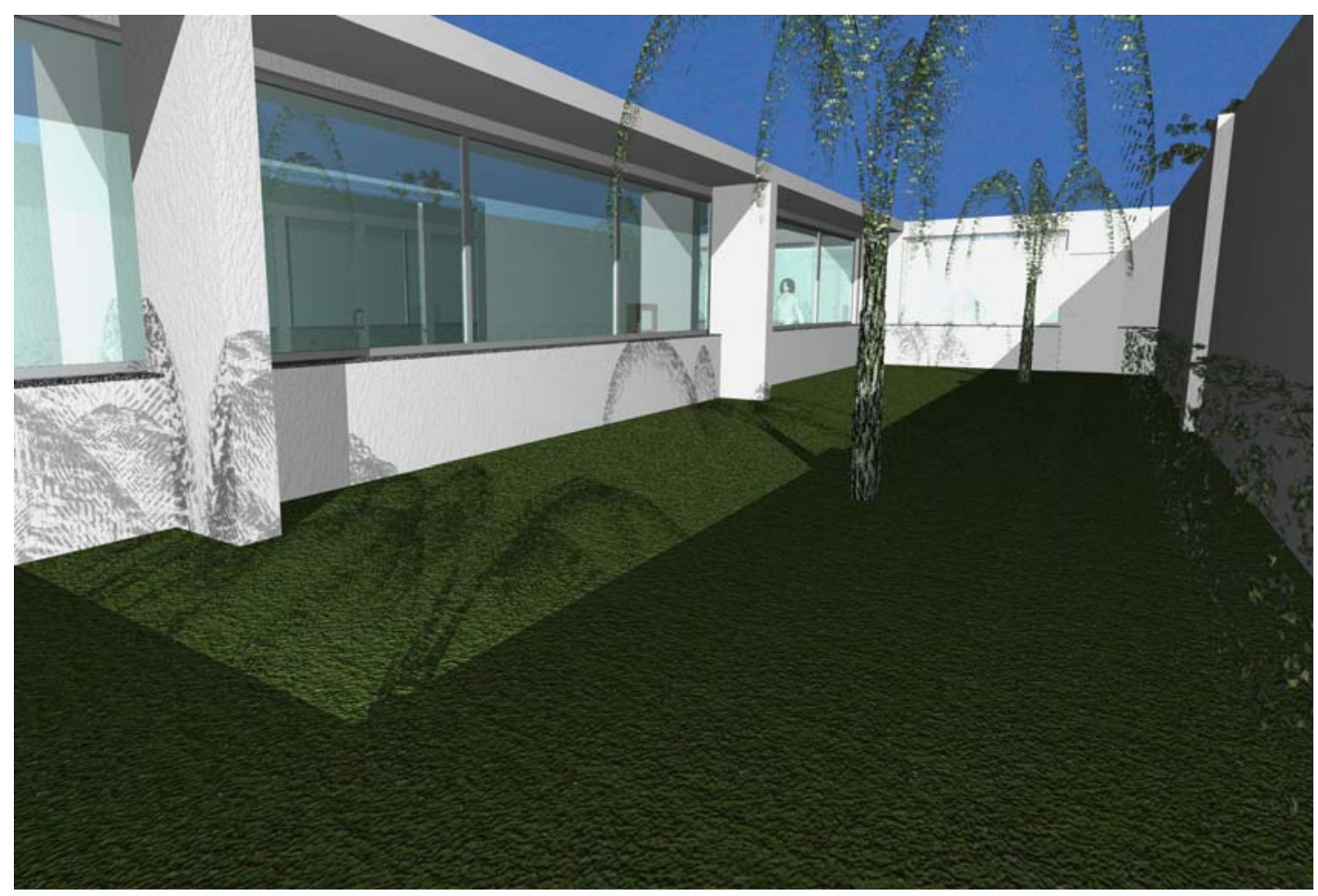

FIGURA 55 - Futuro fechamento do jardim.

A Copa para atendimento aos funcionários será localizada do lado de fora do Biotério, próxima ao jardim, propiciando um lugar agradável para refeição e evitando que odores de animais e alimentos se misturem. Como a copa ficará em uma área adjacente ao jardim, será instalada uma janela para ventilação dessa área.

O guichê a ser instalado na Sala de Expedição servirá para atendimento aos pesquisadores, fornecedores e outros, evitando o acesso à área interna do Biotério. Esse novo procedimento irá melhorar a área do Biotério, no que diz respeito a contaminações, interferências externas, ao controle de exposição aos riscos.

Está sendo criada uma Circulação Independente de Serviço e de entrada de materiais, fundamental para o bom funcionamento do Biotério, sem interferências e isolada do acesso à área de criação de animais. Essa circulação terá ligação com a Sala de Armazenamento de Maravalha e Ração, com a sala destinada à Quarentena e com a sala de experimentação de animais, para proteger tanto os pesquisadores como os animais da área de produção. 
Devido à instalação da fechadura eletrônica e uso de senha programada e individual, na porta de entrada do biotério, apenas pessoas autorizadas poderão ter acesso à área. O acesso à área de criação de animais será feita pelos banheiros, sendo um masculino e outro feminino e após passar pelo chuveiro de acionamento automático, paramentar-se com roupas esterilizadas (FIG.56) e então adentrar a área asséptica.

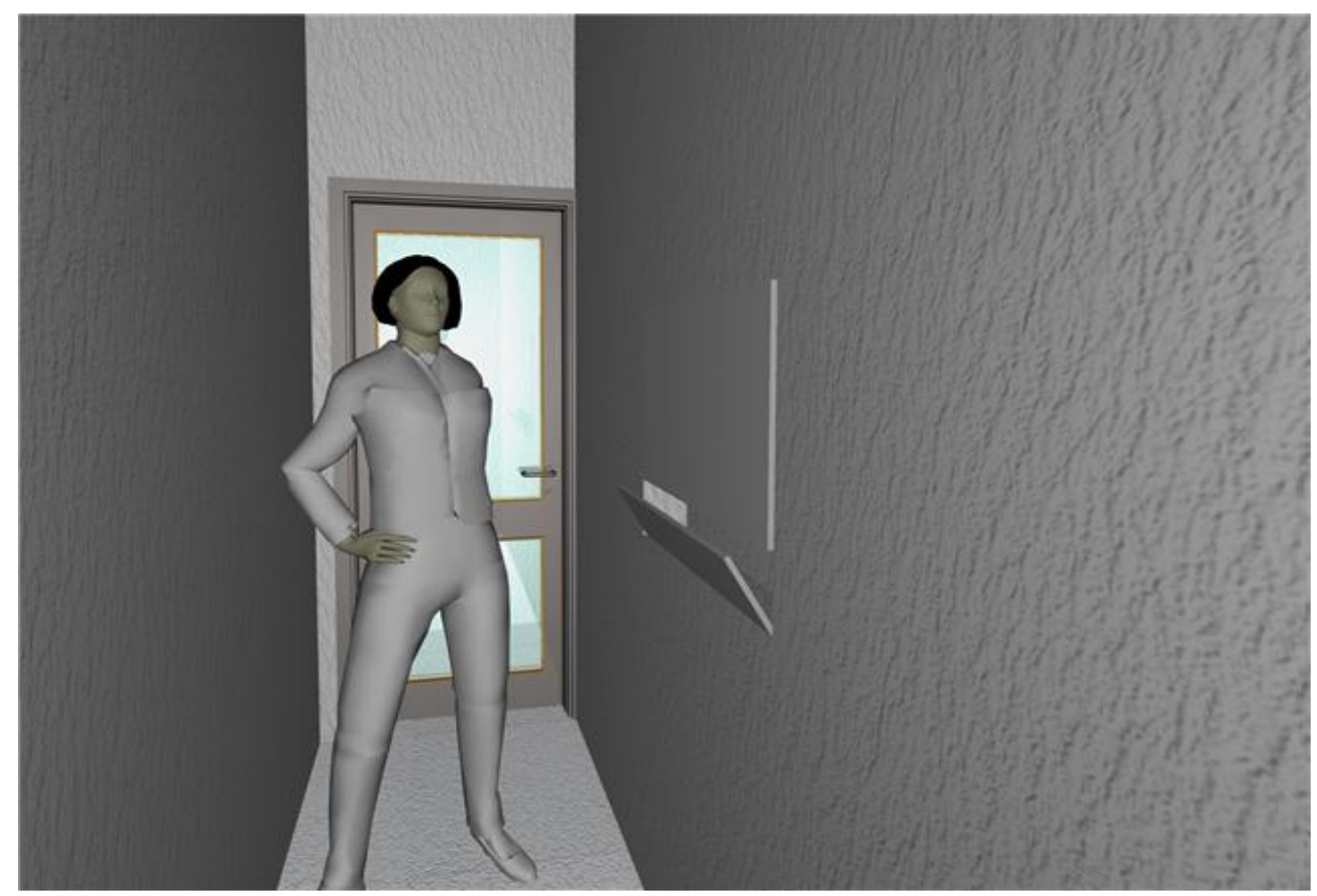

FIGURA 56 - Local para paramentação com roupa estéril.

Da circulação asséptica tem-se acesso à Sala de Preparo, onde existem duas autoclaves de barreira, com uma porta voltada para a sala de lavagem e a outra para a Sala de Preparo de Materiais. As autoclaves de barreira são responsáveis por todo o processo de esterilização dos materiais utilizados nas salas de criação. Na sala de preparo, os funcionários retiram os materiais já autoclavados, como mini-isoladores, bebedouros e outros, que em seguida são separados e preparados adequadamente para utilização nas salas dos animais. Depois desta etapa, o funcionário vai para a Sala de Animais e inicia as trocas. 0 trajeto é direto e a direção é única, evitando ao máximo a contaminação nessa área. 
Após a realização das trocas, os materiais são depositados em carrinhos com rodízios, feitos em aço inoxidável, que ficam localizados na porta de cada sala e posteriormente são levados, pela Circulação "suja", até a Sala de Lavagem. Não existirá mais contra fluxo. O sentido é unidirecional. Só se transita com o material "sujo" nessa circulação denominada séptica. A Sala de Apoio, que está localizada entre as duas passagens para troca da roupa estéril, é o local onde poderá ser guardado o estoque de material para atender a Sala dos Animais.

Com a reforma, vários procedimentos estão sendo modificados, com a intenção de melhorar os fluxos e evitar contaminação cruzada, principalmente com a instalação dos pass through. Foi instalado um pass through, para passagem de material ou animais, da área da Circulação Asséptica para a Sala de Cirurgia. Esse equipamento de segurança limita a movimentação de pessoas no interior da área limpa e também separa as operações sujas. Qualquer material que passa pelo pass through é desinfetado previamente.

Na saída da Sala dos Animais de criação, foi instalado um pass through entre a Circulação Séptica e o Laboratório, para atender a área de experimentação de animais. O material ou animal é entregue sem o contato entre as pessoas, limitando ao máximo a contaminação na área de criação de animais. Outro pass through foi instalado entre a Sala de Fornecimento de Animais e a Circulação Principal de entrada do prédio (FIG. 57), para atendimento externo. O acesso a esta sala só será permitido às pessoas autorizadas que saírem das Salas dos Animais ou pela porta de acesso instalada na Sala de Lavagem, sem interferências com as Salas de Criação.

Na Sala de Fornecimento de animais será instalada uma estante ventilada, onde ficarão os animais retirados das salas de criação até o momento da entrega ao pesquisador. O animal destinado ao fornecimento sairá direto da Sala de Animais, em mini-isoladores, para a sala destinada ao fornecimento externo, e dessa área, entregue aos solicitantes, sem transitar por outras áreas do Biotério. 


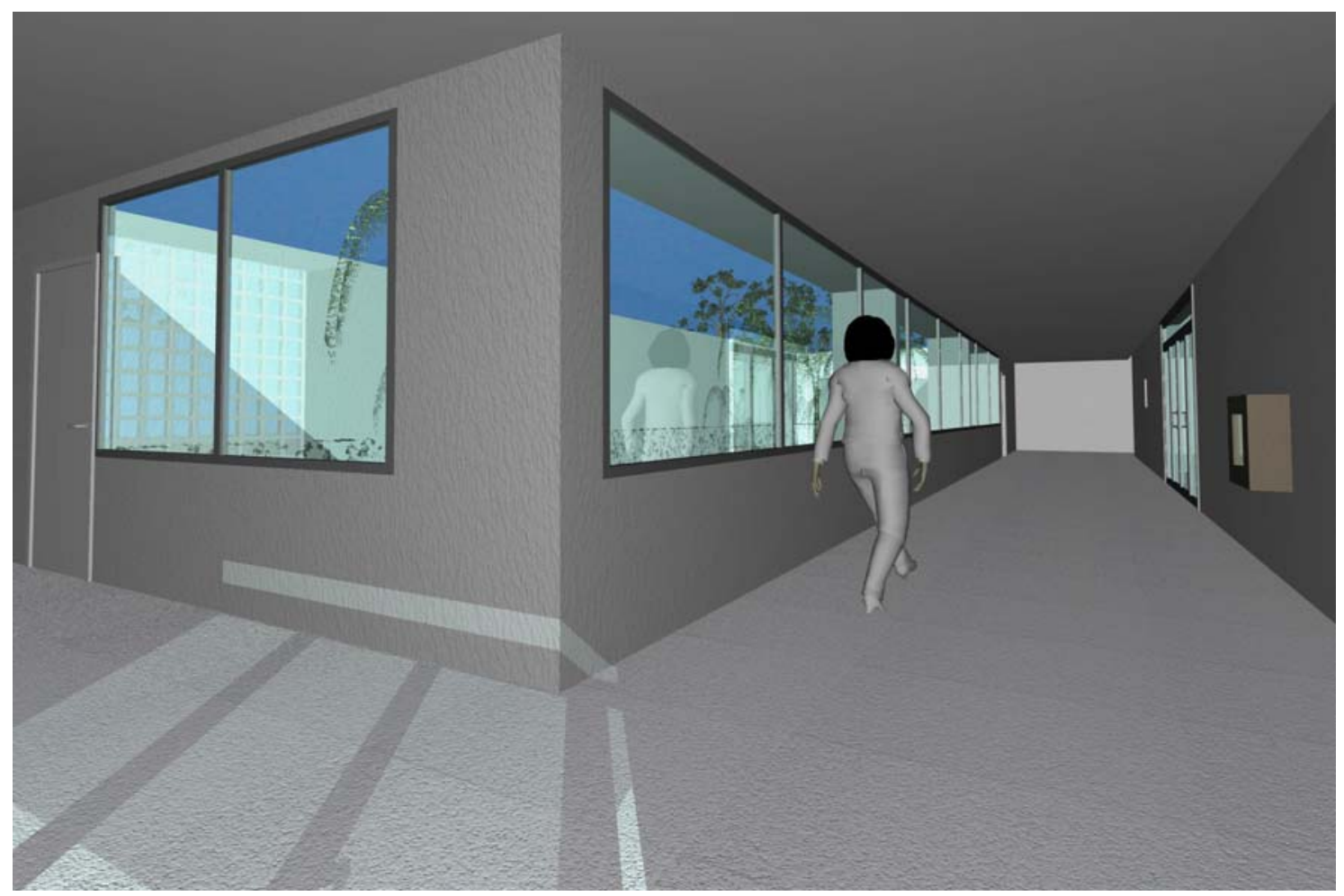

FIGURA 57 - Circulação principal de entrada do prédio.

As divisórias a serem instaladas nas circulações internas do Biotério terão fechaduras com abertura de um só lado da porta e deverão isolar a área de criação de animais, da área da experimentação com coelhos e da futura área de experimentação com mini-pigs.

\section{V.3.1 Considerações críticas sobre a reforma}

Cabe ressaltar, que a reforma do Biotério do IPEN, não se esgota com essas melhorias. Na verdade, alguns materiais que foram adotados, ainda não estão satisfatoriamente adequados. Por exemplo, no caso dos tanques existentes na sala de lavagem, houve uma significativa melhora, mas, o material ideal para seu revestimento seria o aço inoxidável, porém, em função do custo e para poder viabilizar o maior número de itens a serem executados na reforma, adotou-se o revestimento cerâmico que atende às necessidades, no que diz respeito à resistência, mas deixa a desejar em relação as juntas.

Em relação ao forro, o melhor seria que fosse, laje com revestimento em tinta epóxi, teria estanqueidade e menor risco de contaminação. Essa solução não 
foi adotada devido à sobrecarga na estrutura existente do prédio. O piso em granilite é resistente, porém apresenta porosidade, o que com a aplicação da resina acrílica conferiu uma melhora significativa. O piso monolítico com base epóxi atenderia melhor, pois a ausência de juntas lhe confere uma superfície totalmente lisa e resistente a produtos químicos, além de facilitar na higienização e limpeza.

\section{V.4 Memorial descritivo da segunda etapa da adequação e reforma das instalações do Biotério do IPEN/CNEN-SP.}

\section{V.4.1 ESPECIFICAÇÃO}

\section{V.4.1.1 Demolição}

Demolir as alvenarias de elemento vazado existentes nos locais indicados em planta. Demolir alvenarias internas da sala 7, alvenaria para instalação de guichê na sala 1 e alvenarias para instalação de portas nas salas 3, 5, 7, 9, 16, 17, WCM2, vão para ar condicionado nas salas 3 e 4, e vão de 1,60×2,10m para instalação de porta, na área da circulação nova, conforme indicado em planta. Retirar todos os caixilhos (CR) existentes nas salas e do banheiro a ser reformado, conforme indicado em planta. Remover a cobertura existente na área onde será instalada a copa.

Todas as tubulações existentes aparentes deverão ser embutidas nas alvenarias. Retirar porta de entrada em vidro, todas as portas e batentes em madeira, divisórias existentes nas circulações, conforme indicadas em planta. A porta do banheiro WCF1 deverá ser invertida. Remover a porta e batente existente em ferro (PR), dimensão de 1,15x2,40m e instalar no local indicado (PEI) na planta. Considerar no orçamento todos os arremates e acabamentos necessários no piso, alvenarias, batentes em madeira e batentes em aço, após as demolições, bem como a substituição de vidros quebrados.

Os revestimentos em azulejo das alvenarias da sala 7, 12, 13, 17, 18, e do banheiro deverão ser demolidos, bem como todas as louças, metais, acessórios, tubulações e ralos existentes. Remoção total da bancada, tampo em aço 
inoxidável, armários e tubulações na sala 13 e 14. Prever a substituição dos ralos existentes na sala 12, 13, 14 e banheiros WCM2 e WCF2. Substituição da pia do banheiro WCF1.

Prever remanejamento completo da rede de esgoto com tubulações e caixas existentes, na área externa do prédio, no local da nova circulação e na área a ser ampliada, sendo previsto todos os serviços necessários para seu perfeito funcionamento, seguindo o padrão existente no que se refere ao tamanho e paredes das caixas e tampas, materiais empregados e piso a ser refeito.

Demolir o forro em gesso e luminárias existentes nas salas 1 até a sala 18, hall, WCM1, WCF1, WCM2, WCF2 e toda a circulação interna indicada em planta. Fechar com alvenaria vão de porta na sala 16.

Periodicamente será feita a remoção de todo o entulho e detritos que venham a acumular, em decorrência da execução dos serviços, sendo colocados em caçambas e levados para fora do IPEN. Todos os materiais retirados da demolição e que estiverem em bom estado, deverão ser encaminhados pela Contratada, para o prédio do IEC, localizado no IPEN.

\section{V.4.1.2 Fundações}

As superfícies escavadas deverão ser planas, isentas de pedras soltas remanescentes de vegetação ou lixo de qualquer espécie. Os trabalhos de aterro serão executados com material apropriado em camadas sucessivas de no máximo $20 \mathrm{~cm}$, molhadas e fortemente apiloadas, de modo a evitar posteriores fendas, trincas e desníveis por recalque de camadas aterradas. $O$ volume da caixa a ser preenchida com terra deverá atender a cota indicada no projeto. A execução das fundações implicará na responsabilidade integral do Construtor pela resistência das mesmas, pela estabilidade das obras, como também pela estabilidade das construções vizinhas e deverá satisfazer as normas da ABNT referentes ao assunto. Deverá ser executada de acordo com o projeto. 
As formas das vigas baldrame serão em tábuas de pinho de $3^{\mathrm{a}} \mathrm{com}$ gravatas para travamento a cada $0,50 \mathrm{~m}$. Após a concretagem, as vigas deverão permanecer no mínimo 72 horas em processo de cura, devendo ser hidratadas no mínimo a cada12 horas. Para o correto desempenho dos serviços de impermeabilização, todas as superfícies deverão estar absolutamente limpas, secas e com os caimentos e arremates corretamente executados. Vigas baldrames e alvenarias de embasamento deverão ser revestidas com argamassa de cimento e areia no traço 1:3, adicionada com hidrófugo de massa, do tipo Vedacit, na proporção indicada pelo fabricante, recebendo posteriormente pintura à base de emulsão asfáltica nas suas três faces. Lastro de concreto em contato com o solo deverá também ser preparado com adição de hidrófugo de massa.

\section{V.4.1.3 Alvenaria de elevação}

Após a remoção dos caixilhos e porta da sala 16, prever o fechamento nas alvenarias. As alvenarias serão executadas em blocos de concreto, de primeira qualidade, nas dimensões de $14 \times 19 \times 39 \mathrm{~cm}$. Na área da nova circulação e ampliação, as alvenarias terão altura de $2,80 \mathrm{~m}$. A alvenaria que divide os banheiros WCM2 E WCF2 terá altura de 3,30m. As alvenarias da copa terão atura de 2,49m, a mureta do jardim e a alvenaria sob o elemento vazado terão altura de 0,80m, conforme indicado em planta. Para as alvenarias internas dos banheiros serão utilizados blocos de $9 \times 19 \times 39 \mathrm{~cm}$ e altura de $2,00 \mathrm{~m}$. As alvenarias de sustentação das bancadas serão executadas com blocos de 9x19x39cm. Na sala 13, será executada alvenaria em blocos de concreto de $14 \times 19 \times 39 \mathrm{~cm}$, com 1,80m de largura e 1,60m de altura, no local indicado em planta.

O assentamento deve ser com argamassa mista de cimento, cal e areia no traço 1:0,5:8. As fiadas serão executadas perfeitamente niveladas, alinhadas e aprumadas. As juntas terão a espessura máxima de 15mm. Considerar amarração das alvenarias novas com as alvenarias existentes. Não serão aceitos blocos trincados, quebrados ou danificados de qualquer forma. $\mathrm{Na}$ sala 13,

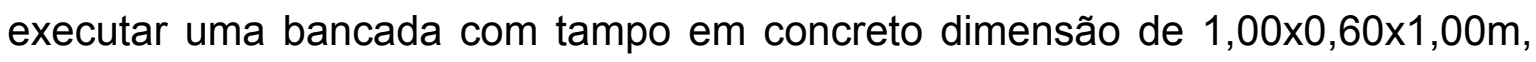
apoiada em alvenarias de bloco de concreto dimensões de $14 \times 19 \times 39 \mathrm{~cm}$. As outras bancadas indicadas no projeto das salas 13 e 14 serão apoiadas em 
alvenarias de bloco de concreto de $14 \times 19 \times 39 \mathrm{~cm}$, com largura indicada em planta e altura de $1,00 \mathrm{~m}$.

\section{V.4.1.4 Revestimento}

As faces das alvenarias novas, alvenarias das bancadas e mureta do jardim deverão receber revestimento em chapisco, massa grossa e massa fina bem desempenada, para posterior pintura. Todas as alvenarias externas existentes deverão receber aplicação de massa fina. O chapisco deve ser em cimento e areia grossa no traço 1:3, a massa grossa (emboço) será constituído de argamassa de cimento, cal em pó e areia média peneirada no traço 1:2:9 ou com argamassa pré-fabricada. A massa fina (reboco) será preparada na obra com pasta de cal e areia fina peneirada no traço 1:3 ou, pré-fabricada. A espessura do emboço não deve ultrapassar a $15 \mathrm{~mm}$, de modo que, com a aplicação de $5 \mathrm{~mm}$ de reboco, o revestimento da argamassa não ultrapasse $20 \mathrm{~mm}$. O reboco somente será executado depois da colocação de peitoris e batentes.

\section{V.4.1.5 Piso}

Nas áreas da circulação nova e ampliação, o reaterro deverá ser executado até a cota prevista em projeto e o solo perfeitamente compactado. Sobre o solo será assentado lastro de concreto magro de $5 \mathrm{~cm}$ de espessura. A execução do contrapiso será em concreto com resistência de $200 \mathrm{~kg} / \mathrm{cm}^{2}$ e espessura de $8 \mathrm{~cm}$. Será aplicada argamassa de regularização sobre o contrapiso. Essa argamassa deve ser aplicada com espessura mínima de $2 \mathrm{~cm}$, traço 1:5 em cimento e areia e acabamento uniforme, para posterior aplicação dos revestimentos. Em toda a área da circulação nova e área a ser ampliada, o piso deverá ser executado em granilite esp $=8 \mathrm{~mm}$, granulometria $\mathrm{n}^{\circ} 1$, com polimento e aplicação de resina. O rodapé deverá ser arredondado, do tipo hospitalar, em granilite, altura de $7 \mathrm{~cm}$, seguindo o mesmo padrão e cor do piso existente, com polimento e aplicação de resina, inclusive na área da copa. No encontro do rodapé com a alvenaria não deverá existir degrau nem saliência, o mesmo deverá facear a alvenaria. 
Todo o piso existente em granilite, nas salas de número 1 até a sala de número 18, banheiro a ser reformado, copa, hall e circulações existentes, deverão ser restaurados, refeitos onde houver necessidade, devido à demolição das alvenarias, executado polimento e posterior aplicação de resina, conforme indicado em planta. Antes da resina, será aplicada em toda a área das salas, copa, hall, circulações e rodapés, existentes e a serem construídos, selador acrílico impermeabilizante tipo Selocryl C-12, para impedir a aderência de sujeira na superfície do piso.

Será aplicado no mínimo 3 demãos de resina epóxi (verniz) tipo Endurox $\mathrm{R} / \mathrm{E}$, bi componente, com elevada resistência química e abrasão, alto brilho, boa resistência à influência das intempéries da água e de grande número de produtos químicos, boa resistência ao calor, boa estabilidade no envelhecimento sob temperaturas de até $100^{\circ} \mathrm{C}$ e boa resistência a corrente superficial. Todo o material necessário para a execução do serviço deverá ser previsto, para a perfeita execução do mesmo. O produto deverá ser aplicado conforme orientação do fabricante. Na área dos banheiros WCM2, WCF2, WCM3 e WCF3, serão instalados piso cerâmico extra, PEI 5, dimensões de $33 \times 33 \mathrm{~cm}$, na cor Rust Branco, Giotoku ou equivalente. O rodapé será do mesmo material do piso e altura de $8,0 \mathrm{~cm}$. Será previsto caimento de $1 \%$ em direção ao ralo.

\section{V.4.1.6 Azulejo}

Todas as faces internas das alvenarias dos banheiros WCM2, WCF2, WCM3, WCF3 e a face da alvenaria da copa onde está localizada a pia, deverão receber revestimento em azulejo, classe A cor branca, Bisotê, Eliane ou equivalente, dimensões de $21 \times 31 \mathrm{~cm}$, do piso até o teto, perfeitamente lisos, com juntas corridas, espessura igual a $1,5 \mathrm{~mm}$, rigorosamente em nível e prumo e rejunte com massa pré-preparada. O assentamento dos azulejos deve ser com argamassa preparada do tipo cimentcola sobre base em massa grossa perfeitamente desempenada. Todas as arestas dos revestimentos de azulejos serão guarnecidas com cantoneiras de alumínio. 


\section{V.4.1.7 Portas}

As portas serão em madeira encabeçada, de primeira linha, ajustáveis nas dimensões indicadas em planta. As portas com visores estão indicadas na planta. O visor será com vidro liso duplo faceando cada lado da porta sem deixar ressalto, transparente, espessura de $5 \mathrm{~mm}$, dimensões de 0,50x0,50 $\mathrm{m}$, seguindo a altura e padrão existente. Será previsto trilho embutido no piso para a porta PC de correr, a ser instalada na sala 13 e dois puxadores metálicos.

Os batentes serão executados em madeira peroba aparelhados, providos de grapas de ferro para chumbamento na alvenaria, devendo receber massa, posteriormente lixados e limpos para receber pintura com tinta esmalte sintético de primeira qualidade, na cor a ser definida. Para os batentes em madeira peroba serão utilizadas guarnições da mesma madeira dos batentes, seguindo o padrão existente. As ferragens serão inteiramente novas, em perfeitas condições de funcionamento e acabamento. Para todas as salas serão usadas fechaduras em metal, do tipo bola, completas com chaves, de $1^{\mathrm{a}}$ linha.

A porta PF será executada em chapa dupla de ferro, dimensão de $1,60 \times 2,10 \mathrm{~m}$, com chaves, trinco superior e inferior, no padrão da porta existente. Para a porta PF será utilizado batente em ferro, dimensionado adequadamente e para as portas internas dos banheiros, os batentes serão em chapa de ferro dobrada $\mathrm{n}^{\circ} 14$, sendo protegidos com tinta antiferruginosa e acabamento com duas demãos de tinta esmalte sintético de primeira qualidade, na cor a ser definida. Para as portas internas dos banheiros WCM2, WCF2, WCM3 e WCF3, serão utilizadas fechaduras em metal do tipo livre-ocupado. Para as demais portas, serão utilizadas fechaduras em metal tipo bola, seguindo o padrão existente. As fechaduras bem como as dobradiças terão acabamento cromado. As dobradiças serão de latão com partes de ferro ou aço e cromadas. Deverão ser robustas, de forma a suportarem, com folga, o regime de trabalho que venham a ser submetidas. Na sua colocação e fixação, deverão ser tomados cuidados especiais para que os rebordos e os encaixes nas esquadrias tenham a forma exata, não sendo permitidos esforços na ferragem para o seu ajuste. 


\section{V.4.1.8 Caixilhos de alumínio}

Os caixilhos deverão ser executados em alumínio anodizado fosco. Os perfis devem ser em alumínio anodizado da Alcoa. O contramarco será em alumínio. A fixação dos caixilhos será feita com no mínimo 2 grapas de ferro de cada lado, em cauda de andorinha, chumbadas na alvenaria com argamassa de cimento e areia 1:3. As grapas serão fixadas ao caixilho através de parafusos de ferro. Deverá ser dada rigorosa atenção na verificação do prumo e nível, bem como no perfeito funcionamento dos caixilhos.

O caixilho CAF deverá ser do tipo fixo, dimensões de 2,10x0,80 m, instalado a 2,00m de altura e vidro liso $5 \mathrm{~mm}$, com aplicação de silicone em todo o perímetro, total de 5 unidades. O caixilho CA1 deverá ser do tipo maxim-ar, dimensões de 0,90×0,60 m, instalado a 2,00m de altura e vidro canelado $5 \mathrm{~mm}$, total de 2 unidades. $\mathrm{O}$ caixilho $\mathrm{CA} 2$ deverá ser do tipo maxim-ar, dimensões de $1,70 \times 0,60 \mathrm{~m}$, instalado a $2,00 \mathrm{~m}$ de altura e vidro canelado $5 \mathrm{~mm}$, total de 2 unidades. O caixilho CA3 deverá ser do tipo maxim-ar, dimensões de 3,00×0,80 $\mathrm{m}$, instalado a 2,00m de altura e vidro liso $5 \mathrm{~mm}$, total de 4 unidades. $O$ caixilho CA4 deverá ser do tipo maxim-ar, dimensões de 5,50×0,80 m, instalado a 2,00m de altura e vidro liso $5 \mathrm{~mm}$, total de 1 unidade.

\section{V.4.1.9 Soleira, peitoril, bancadas e gabinete}

Será executada soleira em granito cinza polido, com $0,15 \mathrm{~m}$ de largura, $0,02 \mathrm{~m}$ de espessura e comprimento dos vãos das portas, nos locais indicados em planta, total de 12 unidades. Sobre toda a mureta do jardim, será instalado peitoril em granito cinza polido, bordas arredondadas, largura de $0,15 \mathrm{~m}$ e espessura de $0,02 \mathrm{~m}$. No local do guichê, será instalado peitoril em granito cinza polido, bordas

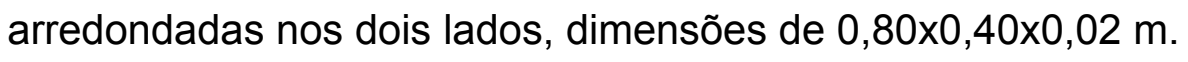

As bancadas a serem instaladas nos banheiros, serão em granito polido,

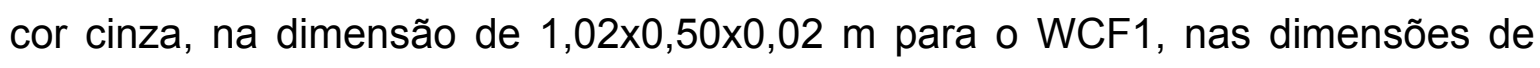
$1,60 \times 0,50 \times 0,02 \mathrm{~m}$ para o WCM2 e WCF2, nas dimensões $1,20 \times 0,50 \times 0,02 \mathrm{~m}$ para o WCM3 e WCF3 e nas dimensões $2,00 \times 0,55 \times 0,02 m$ na copa, com cuba em aço 
inoxidável AISI 304, medindo 0,50X0,40x0,17m. Serão previstos nas bancadas frontão em granito, com 0,12 m de altura, conforme projeto. No encontro da bancada com a alvenaria será feito acabamento em granito com $5 \mathrm{~cm}$ de altura e $2 \mathrm{~cm}$ de espessura. Prever na bancada da copa, ressalto em granito nas partes laterais e frontais, dimensões de $3 \mathrm{~cm}$ de largura por $2 \mathrm{~cm}$ de altura pra evitar que a água escorra.

Será executada sob a bancada da pia da copa, gabinete com fundo, laterais e piso, em compensado de primeira, com $18 \mathrm{~mm}$ de espessura, nas dimensões de 2,00x0,53m e 0,80m de altura. Porta em duas folhas, totalmente em MDF, revestida externamente e internamente em laminado melamínico texturizado, na cor L 532 Alga Marina. Internamente o gabinete e prateleira serão totalmente revestidos em laminado melamínico brilhante, na cor branca. A parte frontal das gavetas deverá ser em MDF revestida com laminado melamínico texturizado, na cor L 532 Alga Marina e internamemte com laminado melamínico brilhante branco. Deverão ser previstos puxadores metálicos cromados para as portas e gavetas, corrediças em aço, deslizante nas laterais das gavetas, para que as mesmas possam abrir e fechar de forma suave, pintadas com pintura eletrostática de epóxi. No local do gabinete será executada base no piso, altura de $7 \mathrm{~cm}$, para que fique suspenso.

Nas salas 13 e 14 serão instaladas bancadas em aço inoxidável, AISI 304, nos locais indicados em planta, com dimensões de 2,00x0,60m, sendo que a metade dessa bancada (dimensão de 1,00x0,60m) terá base em concreto; dimensões de 5,24x0,60m com duas cubas; dimensões de 4,00x0,60m com duas cubas; dimensões de 1,35x0,60m e dimensões de 2,50x0,60m. As cinco bancadas serão instaladas a 1,00m de altura Todas as bordas das bancadas serão elevadas para evitar que a água escorra. As 4 cubas terão dimensões de $0,50 \times 0,40 \times 0,42 m$ e serão localizadas conforme indicação do projeto. Sobre as duas bancadas com cubas, instalar armários suspensos com prateleiras nas dimensões de $3,60 \times 0,37 \mathrm{~m}$ com $0,80 \mathrm{~m}$ de altura e dimensões de 2,80x0,37m com $0,80 \mathrm{~m}$ de altura. Na parte inferior das duas bancadas com cubas, instalar quatro gavetas e armários com prateleiras, dimensões de 5,24x0,58m com 0,80m de 
altura e 4,00x0,58m com 0,80m de altura. Serão previstos dois vãos de 0,80m, em cada bancada, sem armário, conforme projeto.

Sob as três bancadas sem cubas, instalar armários com prateleiras em todos os vãos. Todos os armários terão fundo, laterais e piso e serão executados em compensado de primeira, com $18 \mathrm{~mm}$ de espessura. Porta em duas folhas e parte frontal das gavetas, totalmente em MDF, revestida externamente e internamente em laminado melamínico texturizado, na cor L 532 Alga Marina. Internamente, gavetas e prateleiras, serão totalmente revestidas em laminado melamínico brilhante, na cor branca. Serão previstos puxadores metálicos cromados para as portas e gavetas, corrediças em aço, deslizante nas laterais das gavetas, para que as mesmas possam abrir e fechar de forma suave, pintadas com pintura eletrostática em epóxi.

\section{V.4.1.10 Forro}

Antes da instalação do forro, considerar revisão na estrutura do telhado existente. Em todas as áreas das salas de número 1 até a sala 23 , hall, circulações internas existentes, circulação nova e toda a área a ser ampliada, conforme indicados em planta, serão previstos instalação de forro em gesso tipo acartonado, em painéis aplicados em manta estrutural executada com perfis metálicos tipo "cartola" sustentada por tirantes metálicos fixados na laje. 0 arremate dos cantos será do tipo tabica, para permitir a movimentação do conjunto. Prever fechamento em gesso em todas as laterais do forro, não sendo permitida qualquer abertura ou vão entre o forro e a área interna do prédio. Prever estrutura auxiliar para fixação do forro de gesso. Sob a laje existente na circulação de entrada do prédio, copa, banheiros WCM1, WCF1, WCM2, WCF2, WCM3, WCF3, serão instalados forros em placas de PVC, cor branco, modulação de $625 \times 1250 \mathrm{~mm}$, apoiados em perfis de aço pintado.

\section{V.4.1.11 Portas e caixilhos em vidro}

A porta PV1 será executada em vidro temperado incolor, espessura 10 $\mathrm{mm}$, completa, com dobradiças, ferragens em latão com proteção e acabamento 
cromado, no local indicado em planta. A porta será em uma folha de abrir, dimensão de $0,80 \times 2,10 \mathrm{~m}$ e bandeira fixa de $0,80 \times 0,39 \mathrm{~m}$. Puxadores tubulares em alumínio brilhante. Será utilizada fechadura ref.1520 e contra fechadura ref. 1504, completa com chaves. Para os encaixes dos vidros fixos e bandeira, serão utilizados perfis tipo U. Serão previstos silicone para fixação dos vidros fixos.

A porta PV2 será executada em vidro temperado incolor, espessura $10 \mathrm{~mm}$, completa, trinco na parte inferior da porta, dobradiças e ferragens em latão com proteção e acabamento cromado, no local indicado em planta. A porta será em duas folhas, dimensão de $0,80 \times 2,10 \mathrm{~m}$ cada folha, bandeira e laterais fixas, dimensão total do vão de 2,56×2,49m e duas molas de piso. Puxadores tubulares em alumínio brilhante. Será utilizada fechadura ref.1520 e contra fechadura ref. 1504 , completa com chaves. Para os encaixes dos vidros fixos e bandeira, serão utilizados perfis tipo $U$. Serão previstos silicone para fixação dos vidros fixos. A porta PV3 será executada em vidro temperado incolor, espessura $10 \mathrm{~mm}$, completa, trinco na parte inferior da porta, dobradiças e ferragens em latão com proteção e acabamento cromado, no local indicado em planta. A porta será em duas folhas de abrir, dimensão total de $1,78 \times 2,40 \mathrm{~m}$, duas molas de piso e furo para instalação de fechadura eletrônica. Puxadores tubulares em alumínio brilhante. Será utilizada fechadura eletrônica E-PLEX 5000 completa.

As portas de correr PCVT serão instaladas nos banheiros WCM1 e WCF1. Deverão ser executadas em vidro temperado jateado, espessura $10 \mathrm{~mm}$, completa, com trilho, ferragens em latão com proteção, acabamento cromado, dimensões de $0,80 \times 2,20 \mathrm{~m}$ e $0,88 \times 2,20 \mathrm{~m}$, furo para instalação de fechadura eletrônica e puxadores tubulares em alumínio brilhante. Será utilizada fechadura eletrônica E-PLEX 5000 completa em cada porta. As portas de abrir PVT serão instaladas nos banheiros WCM1 e WCF1. Deverão ser executadas em vidro temperado jateado, espessura $10 \mathrm{~mm}$, completa, com dobradiças, ferragens em latão com proteção e acabamento cromado, no local indicado em planta, dimensão de $0,80 \times 2,20 \mathrm{~m}$ cada. Puxadores tubulares em alumínio brilhante. Será utilizada fechadura ref.1520 e contra fechadura ref. 1504, completa com chaves. Será previsto fechamento no vão (FV) das alvenarias, no local do chuveiro, nos banheiros WCM1e WCF1, com vidro $6 \mathrm{~mm}$, perfil de alumínio tipo $U$ e aplicação de 
silicone no perímetro do vão, dimensões de 2,83x0,80m e 2,68x0,80m. Sobre a mureta, no perímetro do jardim, será executado fechamento até a laje, altura de $1,67 \mathrm{~m}$ e largura indicada na planta, com vidro temperado incolor fixo, espessura $10 \mathrm{~mm}$ e apenas um vidro de correr na área da copa, conforme indicado em planta. Será executado quadro em perfil de alumínio tipo $U$ para a fixação dos vidros e previstos silicone em todo o perímetro do vão, para vedação dos mesmos.

\section{V.4.1.12 Divisórias}

Os locais a serem instaladas as divisórias constam no projeto. Painéis: com $35 \mathrm{~mm}$ de espessura, terão miolo colméia. Seu revestimento será feito em Eucaplac areia Jundiaí. Estrutura: montagem em perfis de alumínio anodizado, na cor natural, composta de travessas e montantes. Modulação: de acordo com as especificações técnicas do fabricante. Serão previstos todos os acessórios para sua instalação e montagem. A divisória será do tipo painel / painel. As portas terão $0,80 \mathrm{~m}$ de largura e $2,10 \mathrm{~m}$ de altura cada folha, sendo $3,30 \mathrm{~m}$ a altura total das divisórias. A fechadura será em metal do tipo bola. Serão instalados em cada folha de porta, visor duplo faceando as portas, sem reentrâncias e saliências, nas dimensões de $0,50 \times 0,50 \mathrm{~m}$.

\section{V.4.1.13 Louças e metais}

As louças e equipamentos deverão ser de primeira linha. Seus respectivos pertences e acessórios deverão ser instalados de acordo com as indicações do projeto, as especificações e recomendações dos fabricantes. O perfeito estado de cada peça deverá ser verificado antes da sua colocação, devendo ser novos e isentos de defeitos de fabricação, transporte e manuseio. Todos os acessórios de ligação de água dos equipamentos deverão ser arrematados com canoplas cromadas. As louças sanitárias deverão ser na cor branco. Os materiais a serem utilizados (TAB.8) e metais sanitários como torneiras, registros de pressão e de gaveta, tubos de ligação metálicos, acessórios sifões etc. deverão ser de primeira linha e cromados. 
TABELA 8 - Lista de materiais propostos a serem utilizados na reforma.

\begin{tabular}{|c|c|}
\hline Materiais Deca ou equivalente & QUANT. \\
\hline Bacia universal & 04 unid. \\
\hline Válvula Hydra Max & 04 unid. \\
\hline Assento para bacia & 04 unid. \\
\hline Papeleira com protetor cromado & 04 unid. \\
\hline Tubo de ligação para bacia & 04 unid. \\
\hline Conjunto de fixação para bacia & 04 unid. \\
\hline Lavatório com coluna L1 Targa & 03 unid. \\
\hline Cuba de embutir oval L33 & 05 unid. \\
\hline Saboneteira de parede cromada & 08 unid. \\
\hline Torneira de mesa com acionamento automático & 08 unid. \\
\hline Válvula de escoamento para cubas e lavatório & 08 unid. \\
\hline Sifão cromado para cubas de embutir e lavatório & 08 unid. \\
\hline $\begin{array}{l}\text { Espelho de cristal bisotado, espessura }=5 \mathrm{~mm} \text {, parafusado, sem moldura, } \\
6 \text { botões cromados em cada espelho. } \\
\text { Dimensões de } 0,80 \times 0,80 \mathrm{~m} \\
\text { Dimensões de } 1,40 \times 0,80 \mathrm{~m} \\
\text { Dimensões de } 1,00 \times 0,80 \mathrm{~m}\end{array}$ & $\begin{array}{l}01 \text { unid. } \\
02 \text { unid. } \\
02 \text { unid. }\end{array}$ \\
\hline Torneira mesa bica alta articulável e válvula pematic embutida no piso & 04 unid. \\
\hline Torneira parede bica móvel com arejador articulável & 01 unid. \\
\hline Válvula para pia americana & 05 unid. \\
\hline Sifão para pia cromado & 05 unid. \\
\hline Registro bruto & 03 unid. \\
\hline Registros de gaveta & 05 unid. \\
\hline Registro de pressão & 02 unid. \\
\hline Chuveiro cromado Tradição & 02 unid. \\
\hline $\begin{array}{l}\text { Ralo sifonado completo com grelha em aço inoxidável tipo abre/fecha } \\
150 \mathrm{~mm}\end{array}$ & 10 unid. \\
\hline
\end{tabular}

\section{V.4.1.14 Bloco de vidro}

Sobre a alvenaria a ser executada, deverá ser executada parede em bloco de vidro, incolor (translúcido ondulado) espessura de 19x19x8cm, área de 2,80 
$\mathrm{m}^{2}$, conforme desenho em planta, sendo previstos todos os materiais necessários para sua perfeita colocação como: Argamassa de assentamento cimentcola cinza. Argamassa de rejuntamento com $1 \mathrm{~cm}$, junta larga AB. Ferro estrutural $\varnothing 3 / 16$ " $(10 \mathrm{~mm})$ em cada fiada de bloco, nos dois sentidos. Gesso como acelerador de pega, caso seja necessário, na preparação da argamassa de assentamento. Espaçadores plásticos tamanho $1 \times 18 \times 8 \mathrm{~cm}$, próprio para bloco de vidro, para alinhar o bloco. Será executada mureta com altura de 0,80 m em alvenaria, devendo ser revestida e posteriormente pintada com tinta látex acrílica, de primeira qualidade, na cor branca.

\section{V.4.1.15 Guichê}

Será instalado guichê de correr em 2 folhas, nas dimensões de $0,80 \times 0,80 \mathrm{~m}$ em vidro temperado $10 \mathrm{~mm}$, instalado a $1,10 \mathrm{~m}$ do piso. Será previsto trinco na parte interna do guichê, trilhos para abertura do vidro e todos os acessórios necessários para a perfeita instalação do guichê. Toda a ferragem será em latão com proteção e acabamento cromado, completo. Do lado interno do guichê será instalado um puxador tubular em alumínio brilhante. Será utilizada fechadura e contra fechadura, completa com chaves.

\section{V.4.1.16 Cobertura}

Será executada cobertura em telha de fibrocimento, sem amianto, tipo Kalheta, ou equivalente, espessura $8 \mathrm{~mm}$, sem amianto, conforme projeto, instaladas de acordo com as normas especificadas pelo fabricante, assim como a montagem e fixação, vãos mínimos e máximos entre apoios e vãos livres, balanço, recobrimento, placas de ventilação a serem instaladas e acessórios de fixação. Os rufos serão instalados no encontro das telhas com as alvenarias, em toda a sua extensão e em volta das colunas existentes, em chapa galvanizada ${ }^{\circ}$ 24, devendo ser pintados com 2 demãos de Neutrol. $\mathrm{Na}$ área do jardim, prever a adequação e mudança, com desvio dos buzinotes, com todas as instalações e tubulações necessárias, para evitar que a água caia nos vidros que serão instalados. 


\section{V.4.1.17 Pintura}

Toda a área com indicação PLA na planta, face interna e externa das alvenarias existentes e novas, hall, forros de gesso e circulações, deverão ser pintadas com duas demãos no mínimo de tinta látex acrílica Suvinil ou equivalente, na cor a ser definida. Todas as alvenarias existentes internas e externas, alvenarias a serem executadas, alvenarias dos WCM1, WCF1 e forro de gesso, deverão ser lixadas, limpas e receber aplicação de massa corrida, antes da pintura.

Todas as portas deverão ser lixadas, limpas, receber massa corrida em toda a área para posterior aplicação de tinta esmalte sintético, Suvinil ou equivalente, na cor a ser definida. A porta PF e batentes em chapa de aço deverão receber proteção com tinta contra ferrugem, antes da pintura.

\section{V.4.1.18 Passeio}

O passeio deverá ser executado no local e na largura indicados no projeto. O piso do passeio será em concreto fck $=13,5 \mathrm{MPa}$, acabamento desempenado à madeira, com juntas de dilatação em ripas de peroba a cada $1,00 \mathrm{~m}$, com espessura de $7 \mathrm{~cm}$. Sobre o solo apiloado será lançado lastro de brita $\mathrm{n}^{\circ} 2$, com 5 $\mathrm{cm}$ de espessura e caimento de $3 \%$ no sentido oposto as paredes. As superfícies dos cimentados serão cuidadosamente curadas, sendo para tal fim, conservadas sob permanente umidade, durante os 7 dias que sucederem sua execução.

\section{V.4.1.19 Cobertura em policarbonato}

Será instalada cobertura em policarbonato curvo, com chapa compacta cristal, apoiada em estrutura de aço pintado, dimensões de 6,86×1,20m e $11,00 \times 1,40 \mathrm{~m}$, nos locais indicados em planta. Deverão ser considerados no orçamento pilares a cada $3,00 \mathrm{~m}$, calha, pingadeira e todos os acessórios para a sua perfeita instalação e montagem. 


\section{V.4.1.20 Instalação elétrica}

As instalações deverão obedecer as normas da ABNT (Associação Brasileira de Normas Técnicas) e ao detalhamento do projeto. As luminárias estão indicadas no projeto. Serão de sobrepor nas áreas sob a laje da copa e circulação do jardim, e de embutir no restante das áreas, com aletas planas, cada uma com 2 lâmpadas fluorescentes de $32 \mathrm{~W}$ e reator de partida rápida (alto fator de potência), da Itaim ou equivalente. Toda a tubulação elétrica na área existente e na área a ser executada deverá ser embutida. Instalar no WCF1, WCM2, WCF2, WCM3, WCF3, 1 tomada universal de embutir de 110V, sobre a bancada da pia e interruptores nos banheiros.

Serão instaladas 4 tomadas tipo universal de embutir de $110 \mathrm{~V}$ e interruptor, na área da copa, sendo três a $1,20 \mathrm{~m}$ do piso e uma a $0,30 \mathrm{~cm}$ do piso. $\mathrm{Na}$ área da nova circulação instalar 2 interruptores para acionamento das luminárias e 2 tomadas universal de embutir de $110 \mathrm{~V}$, a $0,30 \mathrm{~m}$ do piso. Na área da ampliação serão instalados interruptores, 1 tomada tipo universal de $110 \mathrm{~V}$ e $220 \mathrm{~V}$ em cada parede da sala. Serão previstos instalação completa, com tomadas para ar condicionado, nas salas 2, 3, 4 e 6 .

Considerar quadros de distribuição de força (QDF) a serem instalados, conforme diagramas em anexo e redimensionamento dos quadros existentes. Considerar toda rede elétrica necessária para o perfeito funcionamento das tomadas e acionamento das luminárias. Substituir todas as caixas e espelhos existentes no prédio. Instalar quadro de força completo com disjuntores, dimensionados adequadamente e prever a ligação no quadro existente, com todos os materiais necessários ao perfeito funcionamento das instalações.

\section{V.4.1.21 Instalação hidráulica}

Substituir toda a tubulação existente nos banheiros WCM2 e WCF2. Instalação completa de bancada com cuba no banheiro WCF1. Toda a alimentação de água fria será feita através de tubulação em PVC, Tigre ou equivalente, rígido marrom, com junta soldável, do barrilete da caixa d'agua sôbre 
o forro, até os pontos de consumo indicados no projeto. O fornecimento será em tubos com comprimento útil de $6 \mathrm{~m}$. A instaladora deverá montar e instalar todos os aparelhos sanitários e equipamentos constantes do projeto, dimensionados adequadamente, a fim de garantir o perfeito funcionamento das peças e aparelhos.

Será instalado um registro de gaveta em cada banheiro e na copa. Os registros de gaveta deverão ser em bronze com canoplas cromadas. Prever registro com acabamento bruto, para a entrada no prédio. As torneiras de pressão para as cubas serão em metal, com acabamento cromado. As válvulas de escoamento para as cubas serão em metal, acabamento cromado. Sifão para as cubas e lavatórios em metal, acabamento cromado. Os flexíveis serão em metal com acabamento cromado.

Não serão aceitas curvas forçadas nas tubulações, sendo que nas mudanças de direções serão usadas somente peças apropriadas do mesmo material, de forma a se conseguir ângulos perfeitos. Não será permitido amassar ou cortar canoplas, caso seja necessário uma ajustagem, a mesma deverá ser feita com peças apropriadas. A colocação dos aparelhos sanitários deverá ser feita com o máximo de cuidado, de modo a se obter uma vedação perfeita nas ligações de água e nas de esgôto, e um acabamento de primeira qualidade. Os tubos de esgoto e ventilação deverão ser em PVC rígido tipo esgoto, com ponta e bolsa para junta elástica com anel de borracha, e a fabricação atender a norma ABNT. Instalação de ralos sifonados nas salas $12,13,14$, banheiros WCM2, WCF2, WCM3, WCF3 e copa, com ligação completa na rede de esgoto.

Os ralos sifonados deverão ser em PVC rígido, diâmetro 150 mm, com grelha e porta grelha em aço inoxidável tipo abre e fecha. Será instalada caixa de gordura na área externa próxima a copa, com ligação completa na rede de esgoto a ser executada. Serão considerados todos os serviços necessários para o perfeito funcionamento das peças e das instalações. As torneiras das quatro cubas das salas 13 e 14 serão acionadas por meio de válvula pematic embutidas no piso. 
$\mathrm{Na}$ área externa, no local da nova circulação e no local da área a ser ampliada, executar o remanejamento da rede de esgoto, com tubos em PVC, seguindo exatamente o padrão existente, no que diz respeito ao diâmetro das tubulações e conexões, tamanho das caixas e tampas com todos os revestimentos, e acabamentos existentes. As novas caixas deverão ficar aproximadamente $3,50 \mathrm{~m}$ distante das alvenarias. Serão executados todos os serviços necessários para o perfeito funcionamento e ligação na rede de esgoto existente. Caso sejam encontradas caixas ou outras interferências no local da nova circulação, após a demolição da alvenaria de elemento vazado, as mesmas deverão ser deslocadas para o lado externo da alvenaria nova.

$\mathrm{Na}$ área externa da sala 14, serão executadas duas caixas de 1000 litros cada, em alvenaria de bloco de concreto $14 \times 19 \times 39 \mathrm{~cm}$, enterradas no piso, para captação do esgoto radioativo. As caixas deverão ser revestidas, com acabamento totalmente liso e impermeabilizadas. Serão previstos tampas em chapa de ferro dobrada, com bordas de $7 \mathrm{~cm}$ em todo o perímetro da tampa. 0 encaixe das tampas deve ser perfeito para evitar qualquer tipo de vazamento. As tampas deverão receber tratamento contra ferrugem e posteriormente pintadas com tinta esmalte grafite. Prever trinco para cadeado nas duas tampas, registro para cada caixa e toda tubulação necessária para a perfeita ligação das quatro cubas, a serem instaladas nas salas 13 e 14, nas caixas e posterior ligação na rede de esgoto existente. 


\section{CONCLUSÃO}

Devido à importância da ciência dos animais de laboratório, das pesquisas médicas e veterinárias, do conhecimento adquirido pelos profissionais envolvidos nessa área e o bem que a ciência traz para a comunidade, é necessário que as instalações de um biotério sejam bem planejadas, que atendam às necessidades dos usuários e assegurem a saúde e o bem estar dos animais. As adequações realizadas em algumas áreas do Biotério têm proporcionado grandes melhorias no ambiente onde são criados os animais, repercutindo na qualidade e, dessa forma, aumentando a confiabilidade dos resultados dos trabalhos de pesquisa realizados com estes animais.

Embora a adequação não esteja totalmente concluída, já é possível observar-se avanços consideráveis nos procedimentos operacionais do Biotério do IPEN. Houve um ganho sensível de qualidade nas instalações. Cabe ressaltar, que as reformas vêm sendo executadas dentro de determinadas limitações, impostas por restrições existentes na arquitetura do prédio e limitações orçamentárias.

Por outro lado, a proposta apresentada no presente trabalho pode ser executada com uma excelente economia, pois os sistemas e equipamentos instalados permitiram a reativação de componentes essenciais como o sistema de ar, o que seria impossível sem esta tecnologia.

Pode-se afirmar que, após a conclusão das reformas, haverá um ganho significativo:

- no isolamento do Biotério em relação á área externa;

- na segregação das áreas de criação e experimentação;

- na manutenção de animais SPF;

- na expansão da criação de novas linhagens, incluindo AGMs;

- no atendimento aos princípios dos $3 \mathrm{Rs}$;

- na garantia da qualidade e bem-estar dos animais;

- no controle de acesso das pessoas; 
- na saúde dos funcionários;

- na capacitação de Recurso Humanos,

- na melhoria das condições ambientais;

- na implantação de POPs dentro dos padrões internacionais

- no atendimento às Normas de Biossegurança,

- no atendimento dos princípios éticos,

- na modernização dos processos de criação e experimentação.

Deve ser enfatizado, que nesse trabalho, procurou-se atender às recomendações e exigências de acordo com as normas para Animais Geneticamente Modificados (AGM), uma vez que a Lei $n^{\circ} 11.794$, chamada Lei Arouca, ainda não foi regulamentada.

Concluindo, as adequações objetivaram proporcionar um ambiente mais seguro para os animais, para as pessoas e para o meio ambiente, de modo que se possam desenvolver pesquisas envolvendo animais de laboratório buscando sempre grandes avanços científicos em benefício da população brasileira. 


\section{REFERÊNCIAS BIBLIOGRÁFICAS}

ABDELHAY, E.S.F.W., Criação e produção de animais transgênicos e nocautes. In: ANDRADE, A.; PINTO, S.C.; OLIVEIRA, R.S., Animais de Laboratório: criação e experimentação. Rio de Janeiro: Ed. Fiocruz, cap.40, p.345-352, 2006.

ABNT - Associação Brasileira de Normas Técnicas - Resíduos de Serviços de Saúde. Terminologia. NBR - 12807.1993

ALESCO IND. E COM. Disponível em: <http://www.alesco.ind.br>. Acesso em: 05 fev. 2009.

ANDRADE, A., O Bioterismo: evolução e importância. In: ANDRADE A.; PINTO, S.C.; OLIVEIRA, R.S., Animais de laboratório: criação e experimentação. Rio de Janeiro: Ed. Fiocruz, cap.1, p.19-22, 2006.

ANDRADE, A., Segurança em Biotérios. In: Biossegurança: Uma Abordagem Multidisciplinar. Rio de Janeiro: FIOCRUZ, p. 225-237, 1996.

BARBOSA, J.A.R., Estudo sobre a influência dos intervalos de trocas de cama na manutenção de ratos (Rattus norvegicus) acasalados em sistema de ventilação microambiental. Dissertação (Mestrado) - Faculdade de Medicina Veterinária e Zootecnia da Universidade de São Paulo. São Paulo, 1999.

BARBOZA, I., Concepção Analítica de Implantação da Área Física para Biotério Destinado a Ratos e Camundongos Livres de Patógenos Específicos (S.P.F.), em Ambiente Ergonomicamente Projetado na Universidade do Vale do Itajaí. Florianópolis, 128p. Dissertação - Engenharia de Produção, Universidade Federal de Santa Catarina, 2001.

BRASIL. LEI No 11.105, de 24 de março de 2005. Estabelece normas de segurança e mecanismos de fiscalização de atividades que envolvam Organismos Geneticamente Modificados, 2005.

BRASIL. Ministério da Ciência e Tecnologia. Comissão Técnica Nacional de Biossegurança. (CTNBio). Resolução Normativa $n^{\circ}$ 2, de 27 de novembro de 2006.

BRASIL. Ministério da Saúde. Biossegurança em Laboratórios Biomédicos e de Microbiologia. Secretaria de Vigilância em Saúde, Departamento de Vigilância Epidemiológica, - 3. ${ }^{a}$ ed. em português rev. e atual.- Brasília: Ministério da Saúde, (Série A. Normas e Manuais Técnicos), Seção I, p.13-18; Seção II, p.19-28; Seção III, p.29-64; Seção IV, p.65-87; Seção V, p.89-96, 2004.

BRASIL. Ministério da Saúde. Fundação Nacional de Saúde (FUNASA). Diretrizes para projetos físicos de laboratórios de saúde pública. Brasília, cap.1, p.9-10; cap.4, p.56-73, 2004. 
BRASIL. Ministério da Saúde. Secretaria de Ciência, Tecnologia e Insumos Estratégicos. Diretrizes gerais para o trabalho em contenção com material biológico. Brasília, 58p., 2004.

CAMPANER, M.T.F.; SOUZA, P.R.R., Boas práticas em resíduos de serviços de saúde (RSS), Secretaria de Estado de Saúde do Rio de Janeiro, outubro 2002. Disponível em: <http:// www.saúde.ri.gov.br/Docs/cecih/Resíduos OUT 2002.pdf>. Acesso em: 08 fev. 2009.

CARDOSO, T.A.O., Considerações sobre a biossegurança em arquitetura de biotérios. Bol. Centr. Panam. Fiebre Aftosa, 64-67: 3-17, 1998-2001.

CARDOSO, T.A.O., Contenção primária e secundária. In: MOLINARO, E.M.; MAJEROWICZ, J.; VALLE, S., Biossegurança em biotérios. Rio de Janeiro: Ed. Interciência, cap. 3, p. 35-52, 2008.

CARISSIMI, A.S., Manutenção de ratos (Rattus norvegicus) em sistema de ventilçao microambiental com diferentes intervalos de troca de cama: aspectos sanitários e econômicos. Dissertação (Mestrado) - Faculdade de Medicina Veterinária e Zootecnia da Universidade de São Paulo. São Paulo, 1998.

CEMIB - Centro Multidisciplinar para Investigação Biológica. Disponível em: <http://www.cemib.unicamp.br/cemib/quem somos.htm>. Acesso em: 29 nov. 2008.

COSTA, M.A.F.; COSTA, M.F.B.; ROZA, M.R., Qualidade em biossegurança no contexto de biotérios. In: MOLINARO, E.M.; MAJEROWICZ, J.; VALLE, S. Biossegurança em biotérios. Rio de Janeiro: Interciência, cap.4, p.53-66, 2008.

COSTA, M.J.R.P; PINTO, A.A., Bem-estar animal In: RIVERA, E.A.B.; AMARAL, M.H.; NASCIMENTO, V.P. Ética e Bioética: aplicadas à Medicina Veterinária. Goiânia, cap.IV, p.105-130, 2006.

COUTO, S.E.R., Classificação dos animais de laboratório quanto ao status sanitário. In. ANDRADE A.; PINTO, S.C.; OLIVEIRA, R.S. Animais de laboratório: criação e experimentação. Rio de Janeiro: Ed. Fiocruz, cap.8, pag. 59-64, 2006.

COUTO, S.E.R., Instalações e barreiras sanitárias. In. ANDRADE A.; PINTO, S.C.; OLIVEIRA, R.S. Animais de laboratório: criação e experimentação. Rio de Janeiro: Ed. Fiocruz, cap.5, p.33-44, 2006.

CRISSIUMA, A.L.; ALMEIDA, E.C.P., Experimentação e Bem-Estar Animal Artigo de Revisão. Saúde \& Ambiente em Revista, Duque de Caxias, v.1, n.2, p.1-10, jul-dez 2006.

FEIJÓ, A.G.S., Utilização de animais na investigação e docência: uma reflexão necessária. Porto Alegre: EDIPUCRUS, cap.3, p.63-70, 2005. 
FLETCHER JL; MC SHEELY T., Influence of noise on animals. In: The Control of the animal house environment. London: Laboratory Animals Ltd; p.51-62 (Laboratory animals handbooks, 7), 1976.

FIOCRUZ, Manual para técnicos em animais de laboratório. Capacitação de Pessoal de Níveis Elementar e Médio em Biotérios - CPNEMB, DEPARTAMENTO DE BIOTÉRIOS/BIO-MANGUINHOS-FIOCRUZ, Rio de Janeiro, 1994.

FRAJBLAT, M.; AMARAL, V.L.L; RIVERA, E.A.B., Ciência e Cultura - Ciência em Animais de Laboratório. v.60 n.2, São Paulo, 2008. Disponível em: $<$ http://cienciaecultura.bvs.br/scielo.php?script=sci arttex\&pid=S0009-

6725200800020... >. Acesso em: 26 ago. 2008.

FRANÇA, M.B.; PORTO, F., Programação arquitetônica de biotérios. Brasília, DF: Ministério da Educação, 1986.

GILIOLI, R., Controle virológico em animais de laboratório. In: LUCA, R.R.; ALEXANDRE, S.R.; MARQUES T.; SOUZA, N.L.; MERUSSE, J.L.B.; NEVES, S.P. Manual para técnicos em bioterismo. São Paulo: COBEA, cap. 13, p.139148, 1996.

GRIST, N.R., Manual de biossegurança para o laboratório. Livraria Santos Editora. São Paulo. 2ª edição, cap.2, p.7-18, 1995.

JC e-mail 3309. Princípio da Razoabilidade, Sobre Experimentação Animal, Carta da Federação de Sociedades de Biologia Experimental. 19 de julho de 2007.

KABA do Brasil. Disponível em: <http://www.kabadobrasil.com.br>. Acesso em: 22 fev. 2009.

LUNA, S.P.L., Dor e Sofrimento Animal. In. RIVERA, E.A.B.; AMARAL, M.H.; NASCIMENTO, V.P. Ética e Bioética: aplicadas à Medicina Veterinária. Goiânia, cap. V, p.131-158, 2006.

MAJEROWICZ, J., Boas Práticas em Biotérios e Biossegurança. Rio de Janeiro: Interciência, cap.8, p.103-123, 2008.

MAJEROWICZ, J. Procedimentos de biossegurança para as novas instalações do laboratório de experimentação animal (Laean) de BioManguinhos. Rio de Janeiro, 2005, 92 p. Dissertação (Mestrado) - Instituto Oswaldo Cruz.

MEZADRI, T.J.; TOMÁZ, V.A.; AMARAL, V.L.L., Animais de laboratório: Cuidados na iniciação experimental. Florianópolis: Editora da UFSC, cap.1, p.1938; cap.2, p.39-52; cap.3, 55-68; cap.4, p.71-100, 2004.

MOLINARO, E.M.; MAJEROWICZ, J.; VALLE, S., Biossegurança em Biotérios. Rio de Janeiro: Interciência, cap.3, p.35-52, 2008. 
NACONECY, C.M., Ética \& Animais: um guia de argumentação filosófica. Porto Alegre: EDIPUCRUS, 234p., 2006.

NASCIMENTO, N., Comunicação Pessoal, Recuperação de área do biotério para ampliação do plantel de animais com qualidade sanitária controlada Projeto submetido ao CNPq. IPEN/CNEN-SP - 2005.

NRC National Research Council. Manual sobre Cuidados e Usos de Animais de Laboratório. AAALAC E COBEA. Goiânia, cap.2, p.27-74; cap.3, p.75- 95; cap.4, 96-109, 2003.

OMS (Organização Mundial da Saúde). Manual de segurança biológica em laboratório. Terceira edição. Genebra, cap.1, p.5-46; cap.2, p.47-50, 2004.

PAIVA, F.P.P.; MAFFILI, V. V.; SANTOS, A. C. S., Curso de Manipulação de Animais de Laboratório. Ministério da Saúde. Centro de Pesquisas Gonçalo Moniz. FIOCRUZ. Salvador - Bahia. Maio, 2005.

PASSOS, L.A.C., Comunicação Pessoal, Projeto de Adequação do Biotério de Animais Padronizados do Instituto de Pesquisas Energéticas e Nucleares IPEN, 2001.

PESSOA, M.C.T.R.; LAPA, R.C.C.; VIEIRA, V.M., Arquitetura e biossegurança. In: MOLINARO, E.M.; MAJEROWICZ, J.; VALLE, S., Biossegurança em biotérios. Rio de Janeiro: Ed. Interciência, cap.2, p.19-33, 2008.

RIVERA, E.A.B., Estresse em Animais de Laboratório. In: ANDRADE A.; PINTO, S.C.; OLIVEIRA, R.S., Animais de Laboratório: criação e experimentação. Rio de Janeiro: Ed. Fiocruz, cap.29, p.263-273, 2006.

RIVERA, E.A.B., Ética, bem-estar e legislação. In: LUCA, R.R.; ALEXANDRE S.R.; MARQUES, T.; SOUZA, N.L.; MERUSSE, J.L.B.; NEVES, S.P., Manual para técnicos em bioterismo. 2.ed. revisada e ampliada - São Paulo: H.A. Rothschild, cap.2, p.11-14, 1990.

RIVERA, E.A.B., Ética na experimentação animal. In: ANDRADE, A.; PINTO, S.C; OLIVEIRA, R.S., Animais de Laboratório: criação e experimentação. Rio de Janeiro: Ed. Fiocruz, cap.3, p.25-28, 2006.

RIVERA, E.A.B., Ética na experimentação animal e alternativas ao uso de animais em pesquisa e teste. In: RIVERA, E.A.B.; AMARAL, M.H.; NASCIMENTO, V.P., Ética e Bioética: aplicadas à Medicina Veterinária. Goiânia, cap.VI, p.159-185, 2006.

RIVERA, E.A.B., Legislação e comitês de ética na experimentação animal. In: RIVERA, E.A.B.; AMARAL, M.H.; NASCIMENTO, V.P., Ética e Bioética: aplicadas à Medicina Veterinária. Goiânia, cap.VII, p.187-212, 2006.

RUYS, T., Handbook of Facilities Planning. Laboratory Animal Facilities. Volume 2, Van Nostrand Reinhold, New York, cap.1, p.1-80, 1991. 
SANTOS, B.F., Classificação dos Animais de Laboratório quanto ao Status Genético. In: ANDRADE A.; PINTO, S.C.; OLIVEIRA, R.S., Animais de Laboratório: criação e experimentação. Rio de Janeiro: Ed. Fiocruz, cap.9, p.6570, 2006.

SANTOS, B.F., Macro e microambientes. In: ANDRADE A.; PINTO, S.C.; OLIVEIRA, R.S., Animais de Laboratório: criação e experimentação. Rio de Janeiro: Ed. Fiocruz, cap.7, p.55-58, 2006.

SILVA, F.H.A.L., EPI E EPC COMO BARREIRAS. Núcleo de Biossegurança/DSSA-ENSP - $\quad$ Fiocruz. Disponível em: $<$ http://www.cpqrr.fiocruz.br/posgraduação/cienciadasaude/apoio/Biossegurança/3 8\%20-\%20EPI\%20E\%20EPC\%20COMO\%20BARREIRAS.pdf>. Acesso em: 09 fev. 2009.

SOUZA, N.L.; MERUSSE, J.L.B., A utilização de animais de laboratório. In. LUCA, R.R.; ALEXANDRE, S.R.; MARQUES T.; SOUZA, N.L.; MERUSSE, J.L.B.; NEVES, S.P., Manual para técnicos em bioterismo. São Paulo: COBEA, cap. 1, p.3-10, 1996.

SPARRENBERGER, F.; SANTOS,I.; LIMA, R.C., Epidemiologia do distress psicológico: estudo transversal de base populacional. Rev. Saúde Pública, 37(4): 434-9, 2003.

TEIXEIRA, M.A., Ventilação microambiental para biotérios: estudo experimental em camundongos (Mus musculus). Dissertação (Mestrado) - Faculdade de Medicina Veterinária e Zootecnia da Universidade de São Paulo. São Paulo, 1995.

TORU URANO K.N.; GUANGCHENG J.; TSUKUMI K., Survey of pseudomona aeruginosa contamination in human beings and laboratory animals. Exp Anim; 44(3): 233-239, 1995.

VALERO, V.B.; ANTENOR, A. e cols; GUIMARÃES, H.B.; LAUS, J.E.; MERUSSI, J.L.B.; PASSOS, L.A.C.; CHAGURI, L.A.G.; MALACCO, M. A. F.; BELLINI, M. H.; REICHMANN, M.L.; BRAGGIO, M.M.; SOUZA, N.L.; LUCA, R.R.; SOARES, S.R.C.; NEVES, S.M.P.; MASSIRONI, S.M.G.; MARQUES, T., Manual para técnicos de biotério. Ed. Hanna A. Rothschild, 1.ed. - São Paulo: Finep, cap.1, p.1-9; cap.3, p.15-46; cap.10, p.110-130, 1990.

WEIHE W.H., The effect of light on animals. In: The Control of the animal house environment. London: Laboratory Animals Ltd; pp.63-67. (Laboratory animal handbooks, 7), 1976. 